FACTORS AFFECTING LEACHING IN AGRICULTURAL AREAS AND AN ASSESSMENT OF AGRICULTURAL CHEMICALS IN THE GROUND WATER OF KANSAS

By Charles A. Perry, F. Victor Robbins, and Philip L. Barnes

U.S. GEOLOGICAL SURVEY

Water-Resources Investigations Report 88-4104

Prepared in cooperation with the

KANSAS DEPARTMENT OF HEALTH AND ENVIRONMENT

Lawrence, Kansas

1988 


\section{DEPARTMENT OF THE INTERIOR \\ DONALD PAUL HODEL, Secretary \\ U.S. GEOLOGICAL SURVEY \\ Dallas L. Peck, Director}

For additional information write to:

District Chief

U.S. Geological Survey

1950 Constant Avenue - Campus West

Lawrence, Kansas 66046
Copies of this report can be purchased from:

U.S. Geological Survey

Books and Open-File Reports

Denver Federal Center, Bldg. 810

Box 25425

Denver, Colorado 80225 


\section{CONTENTS}

Page

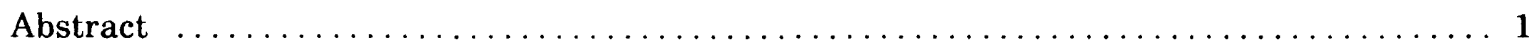

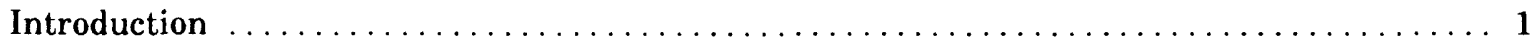

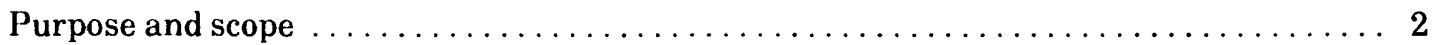

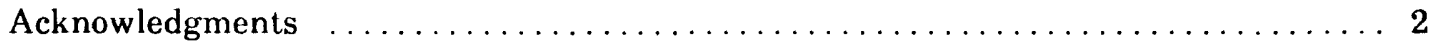

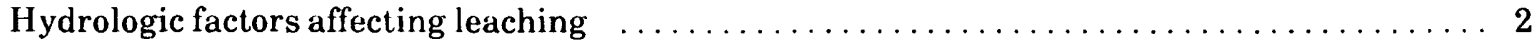

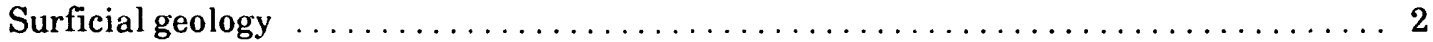

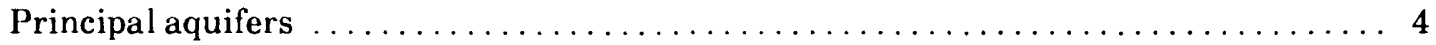

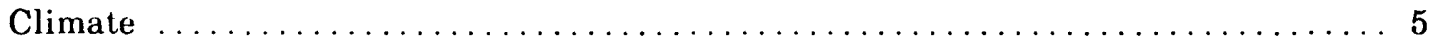

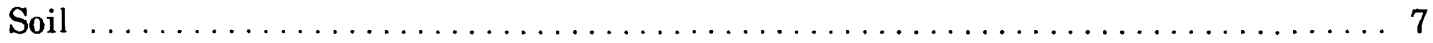

Agricultural and chemical factors affecting ground-water quality $\ldots \ldots \ldots \ldots \ldots \ldots \ldots 11$

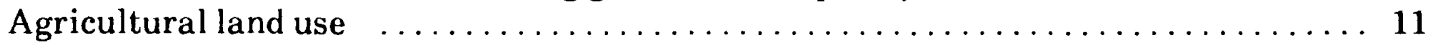

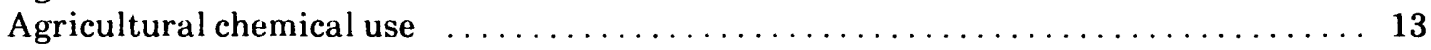

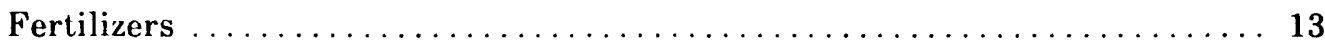

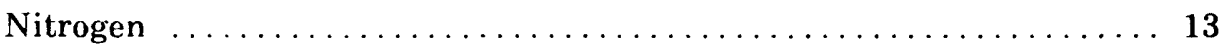

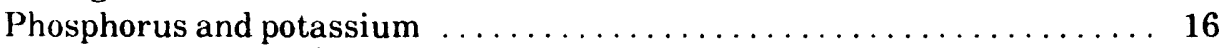

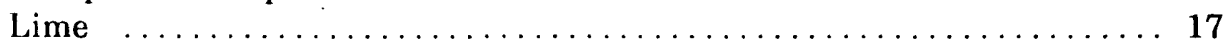

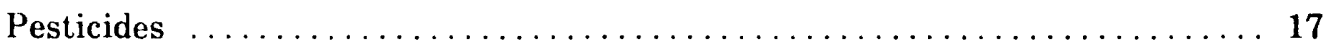

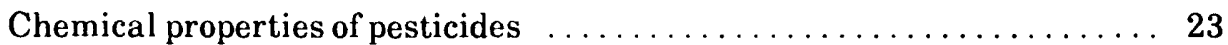

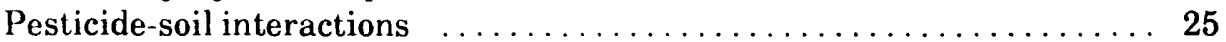

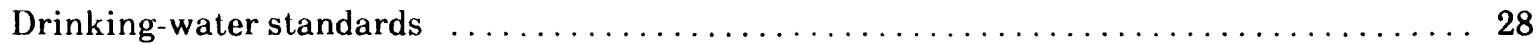

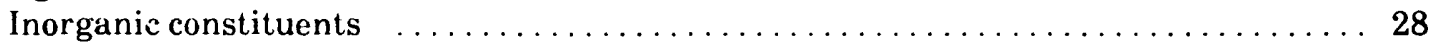

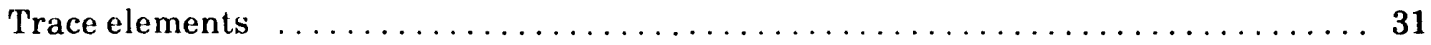

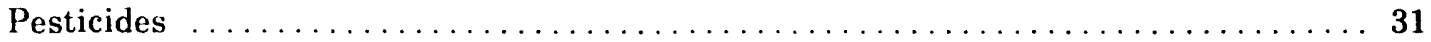

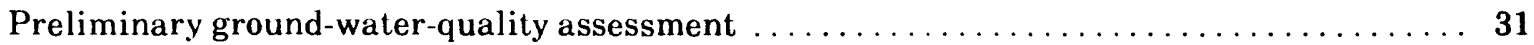

Kansas ground-water-quality monitoring network, $1976-81 \ldots \ldots \ldots \ldots \ldots \ldots \ldots \ldots$

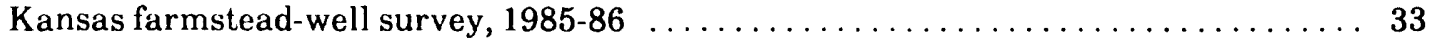

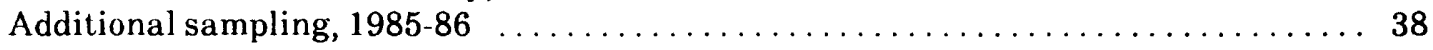

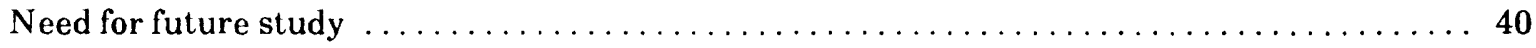

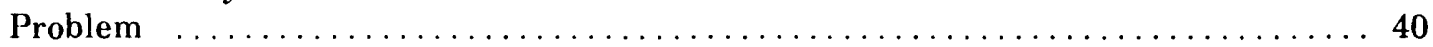

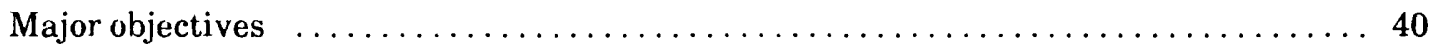

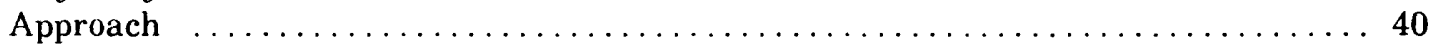

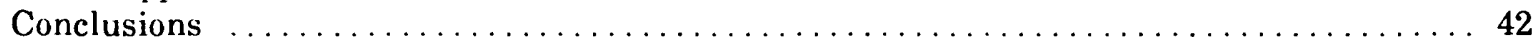

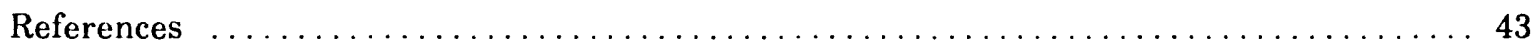

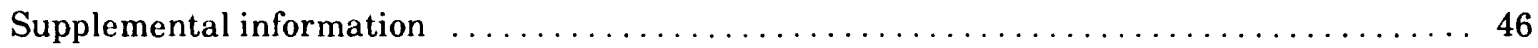

$\begin{array}{ll}\text { Figure } & \text { Page }\end{array}$

1. Map and cross section showing generalized geology and physiographic provinces ... 3

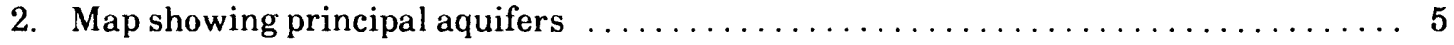

3. Map showing average annual precipitation, 1951-80, and precipitation reporting districts of the National Oceanic and Atmospheric Administration $\ldots \ldots \ldots \ldots \ldots 6$

4. Graph showing average monthly precipitation in Kansas as a percentage of total

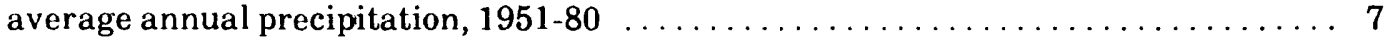

5. Diagram showing classification of soil textures $\ldots \ldots \ldots \ldots \ldots \ldots \ldots \ldots \ldots$

6. Diagram showing typical soil-moisture-release curves for three common soil types . 10

7. Map showing distribution of leachability classes of Kansas soil $\ldots \ldots \ldots \ldots \ldots \ldots 12$

8. Map showing ground-water regions and percentage of ground-water samples with dissolved nitrate-nitrogen concentrations exceeding drinking-water standard of 10 milligrams per liter 
9. Map showing location of Kansas State University agronomy farms and experimental stations

Table

Page

1. Average annual precipitation, $1951-80$, for nine reporting districts $\ldots \ldots \ldots \ldots 6$

2. Number of irrigated acres in 1984 for nine reporting districts $\ldots \ldots \ldots \ldots \ldots \ldots \ldots$

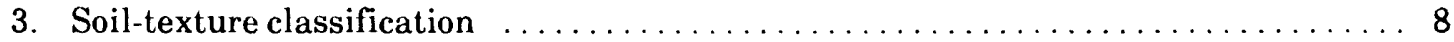

4. Typical soil-moisture levels for three soil textures $\ldots \ldots \ldots \ldots \ldots \ldots \ldots \ldots \ldots$

5. Annual crop-moisture use for typical Kansas crops $\ldots \ldots \ldots \ldots \ldots \ldots \ldots \ldots \ldots \ldots$

6. Number of acres in each leachability class in Kansas $\ldots \ldots \ldots \ldots \ldots \ldots \ldots \ldots \ldots$

7. Common fertilizers and their chemical formulas $\ldots \ldots \ldots \ldots \ldots \ldots \ldots \ldots \ldots \ldots$

8. Nitrogen application rates for alternative timing of application $\ldots \ldots \ldots \ldots \ldots \ldots$

9. Nitrogen application rates recommended by Kansas Cooperative Extension

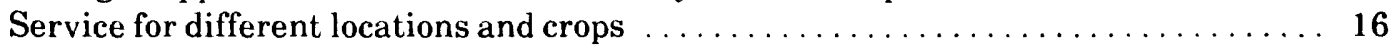

10. Pesticide usage on crops and pasture or rangeland in Kansas, $1978 \ldots \ldots \ldots \ldots .18$

11. Total and irrigated crop acreages during 1978 and $1984 \ldots \ldots \ldots \ldots \ldots \ldots \ldots \ldots \ldots$

12. Chemical properties and toxicity of selected pesticides $\ldots \ldots \ldots \ldots \ldots \ldots \ldots$

13. Summary of drinking-water standards and recommended limits for inorganic

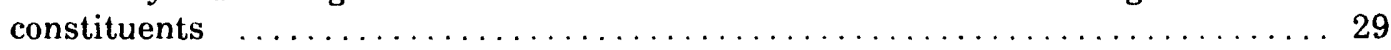

14. Summary of drinking-water standards and chronic health effects for trace elements 32

15. Health advisory levels for pesticides in drinking water $\ldots \ldots \ldots \ldots \ldots \ldots \ldots . \ldots \ldots$

16. Dissolved nitrate-nitrogen concentrations in Kansas ground-water supplies, 1976-81 37

17. Pesticides detected in Kansas ground water, $1985-86 \ldots \ldots \ldots \ldots \ldots \ldots \ldots \ldots \ldots$

18. Major herbicide usage during 1978 , by reporting district $\ldots \ldots \ldots \ldots \ldots \ldots \ldots 4$

\section{CONVERSION FACTORS}

Information in the following table may be used to convert the inch-pound units of measurement used in this report to metric (International System) units:

$\begin{array}{lcl}\text { Multiply inch-pound unit } & \text { By } & \text { To obtain metric unit } \\ \text { inch } & 25.4 & \text { millimeter } \\ \text { foot } & 0.3048 & \text { meter } \\ \text { mile } & 1.609 & \text { kilometer } \\ \text { acre } & 4,047 & \text { square meter } \\ \text { quart } & 0.9464 & \text { liter } \\ \text { pound } & 453.6 & \text { gram } \\ \text { ounce } & 28,349 & \text { milligram } \\ \text { ton (short) } & 0.9072 & \text { megagram } \\ \text { pound per acre }(\mathrm{lb} / \mathrm{acre}) & 0.112 & \text { gram per square meter } \\ \text { inch per foot } & 83.333 & \text { millimeter per meter } \\ \text { gallon per minute } & 0.06308 & \text { liter per second } \\ \text { pound per square inch } & 6.895 & \text { kilopascal } \\ \text { degree Fahrenheit }\left({ }^{\circ} \mathrm{F}\right) & { }^{\circ} \mathrm{C}=5 / 9\left({ }^{\circ} \mathrm{F}-32\right) & \text { degree Celsius }\left({ }^{\circ} \mathrm{C}\right) \\ \end{array}$

Sea level: In this report, sea level refers to the National Geodetic Vertical Datum of 1929--a geodetic datum derived from a general adjustment of the first-order level nets of both the United States and Canada, formerly called "Mean Sea Level." 


\title{
FACTORS AFFECTING LEACHING IN AGRICULTURAL AREAS AND AN ASSESSMENT OF AGRICULTURAL CHEMICALS IN THE GROUND WA'TER OF KANSAS
}

\author{
By Charles A. Perry1, Victor Robbins2, and Philip L. Barnes3
}

\section{ABSTRACT}

Hydrologic factors and agricultural practices that affect the leaching of agricultural chemicals were assessed to evaluate the extent and severity of chemical contamination of ground water in Kansas. Climate, surficial geology, soil type, and principal aquifers determine the types of crops suitable to be planted, types of tillage, conservation and irrigation practices, and affect the quantity and method of application of agricultural chemicals.

In general, the more sand in the soil the more susceptible it will be to leaching of agricultural chemicals. Soils in Kansas are grouped into four classes of leachability--from class 1 , with the largest permeability, to class 4 , with the smallest.

As a result of years of nitrogen application to the soil, the 10-milligram-per-liter drinkingwater standard for nitrate-nitrogen was exceeded occasionally in 13 of 14 geohydrologic regions in the State.

During 1978, about 23.8 million pounds of herbicides and 4.3 million pounds of insecticides were used in the State. Atrazine was the most extensively used herbicide, with 5.7 million pounds applied. However, in areal extent, 2,4-D was the most extensively used, being applied to more than 4 million acres.

One or more herbicides were detected in water samples from 11 of 56 wells during 198586. These wells were located in areas susceptible to agricultural leaching. Atrazine was the most common herbicide detected; it

1 U.S. Geological Survey, Lawrence, Kans.

2 Kansas Department of Health and Environment, Topeka, Kans.

3 Kansas State University, Manhattan, Kans. was detected in water at 9 of 11 wells. Cyanazine was detected in water at three wells; metolachlor at two wells; and metribuzin, alachlor, simazine, and propazine were detected at one well each.

Because the largest concentrations of atrazine (46 micrograms per liter), cyanazine (3.7 micrograms per liter), metolachlor (55 micrograms per liter), and the only detectable concentrations of metribuzin (14 micrograms per liter) and alachlor (1.9 micrograms per liter) were from water at only one site, it is uncertain how widespread the problem of large concentrations of these herbicides is throughout the State. The herbicides 2,4-D, 2,4,5-T, picloram, and alachlor and the insecticides chlordane and heptachlor epoxide have been detected by other researchers in ground water from domestic-supply wells in the State.

A plan for a proposed study of the leaching and fate of pesticides in the saturated and unsaturated zones in Kansas includes a comprehensive investigation of pesticides in soil and ground water, data collection, process interpretation, and numerical modeling.

\section{INTRODUCTION}

Contamination of ground-water resources by potentially toxic agricultural chemicals is increasing. The use of fertilizers and pesticides in Kansas has increased significantly during the past three decades. Most cropland is fertilized (Freeze and Cherry, 1979), and a part of this fertilizer reaches the water table. Pesticides encompass a variety of organic chemicals with greatly differing properties that affect their behavioral patterns and ultimate environmental fate. During 1978, an estimated 28.1 million pounds of herbicides and insecticides were applied to Kansas soils and crops (Nilson and Johnson, 1980). As a result of this extensive use, introduction of pesticides 
into the subsurface environment becomes possible, as indicated by residues of pesticides being detected in shallow aquifers in farming areas free from other manmade chemical inputs. For example, the herbicides atrazine, 2,4-D, $2,4,5$-T, picloram, and alachlor and the insecticides chlordane and heptachlor epoxide (degradation product of heptachlor) have been detected in domestic-supply wells in Kansas (Steichen and others, 1986). Ground water in areas where the water table is near the land surface and in areas where the soil and vadose zones consist of permeable sand may be the most susceptible to contamination by agricultural chemicals.

Little is known about the leaching and fate of agricultural chemicals in the subsurface environment. To understand the dynamics and fate of these chemicals in hydrologic settings, it is necessary to understand the factors that affect the environmental fate of agricultural chemicals.

\section{Purpose and Scope}

The purposes of this report are to: (1) Describe the physical, geological, and climatological factors that affect the leaching and fate of agricultural chemicals in the saturated and unsaturated zones in Kansas; (2) describe the agricultural practices, such as minimum tillage or double-cropping, and their possible relation to the type and quantity of applied chemicals; (3) tabulate fertilizer and pesticide applications (weight and acreage) throughout the State; (4) present a description of the complexities of pesticide-soil interactions; (5) tabulate the most commonly used pesticides in Kansas with their chemical properties, toxicities, and application rates; (6) examine ground-water analyses for pesticides at selected sites; and (7) outline a plan of study for a much needed comprehensive investigation of the leaching and fate of agricultural pesticides in the saturated and unsaturated zones in Kansas.

\section{Acknowledgments}

The study described in this report was conducted in 1985-86 by the U.S. Geological Survey in cooperation with the Kansas Department of Health and Environment. The authors gratefully acknowledge the assistance of the Kansas State University Agronomy Farms, especially personnel from the Kansas River Valley Agronomy Experimental Field, Topeka, Kans. Their assistance included compilation of agricultural factors.

\section{HYDROLOGIC FACTORS AFFECTING LEACHING}

The hydrologic factors that affect the response of the environment to chemical applications are numerous and varied. The geology of an area is generally responsible for the type of soil found at the surface, the structure of the underlying vadose zone, and the material that comprises the saturated zone (aquifer). The climate of a particular area determines the availability of water, at the surface and in the ground, for the growth of plants. This in turn determines the types of crops to be planted or whether the land is to be used for pasture. Agricultural practices, including types of tillage, conservation practices, and irrigation, can have an important effect on the hydrology of certain areas.

\section{Surficial Geology}

Kansas is part of the Great Plains physiographic province that extends from Canada to Mexico east of the Rocky Mountains (Fenneman, 1946). The land surface generally slopes eastward from a maximum altitude of 4,135 feet above sea level along the western border with Colorado to a low of about 700 feet above sea level where the Verdigris River crosses into Oklahoma. The oldest rocks are exposed in the extreme southeast part of the State where outcrops of Mississippian age occur in the Ozark Plateaus (fig. 1). The rocks are progressively younger and increase in altitude to the west.

The eastern one-third of the State has outcrops of Pennsylvanian- and Permian-age rocks. This part of Kansas is called the Osage Plains (Fenneman, 1946). In this area, eastfacing limestone escarpments lie between gently rolling plains that were formed from softer rocks, such as shale. Soil along the escarpments is generally rocky and is not farmed. Soil formed from the softer rocks in the eastern one-third of the State is relatively impermeable except along the flood plains of rivers and streams 


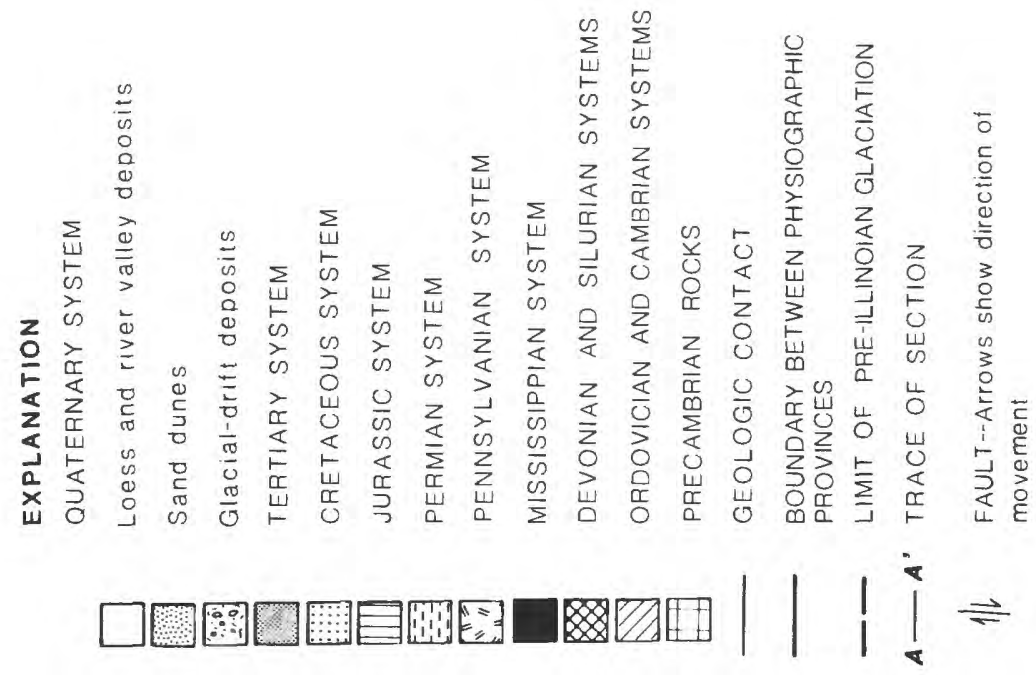
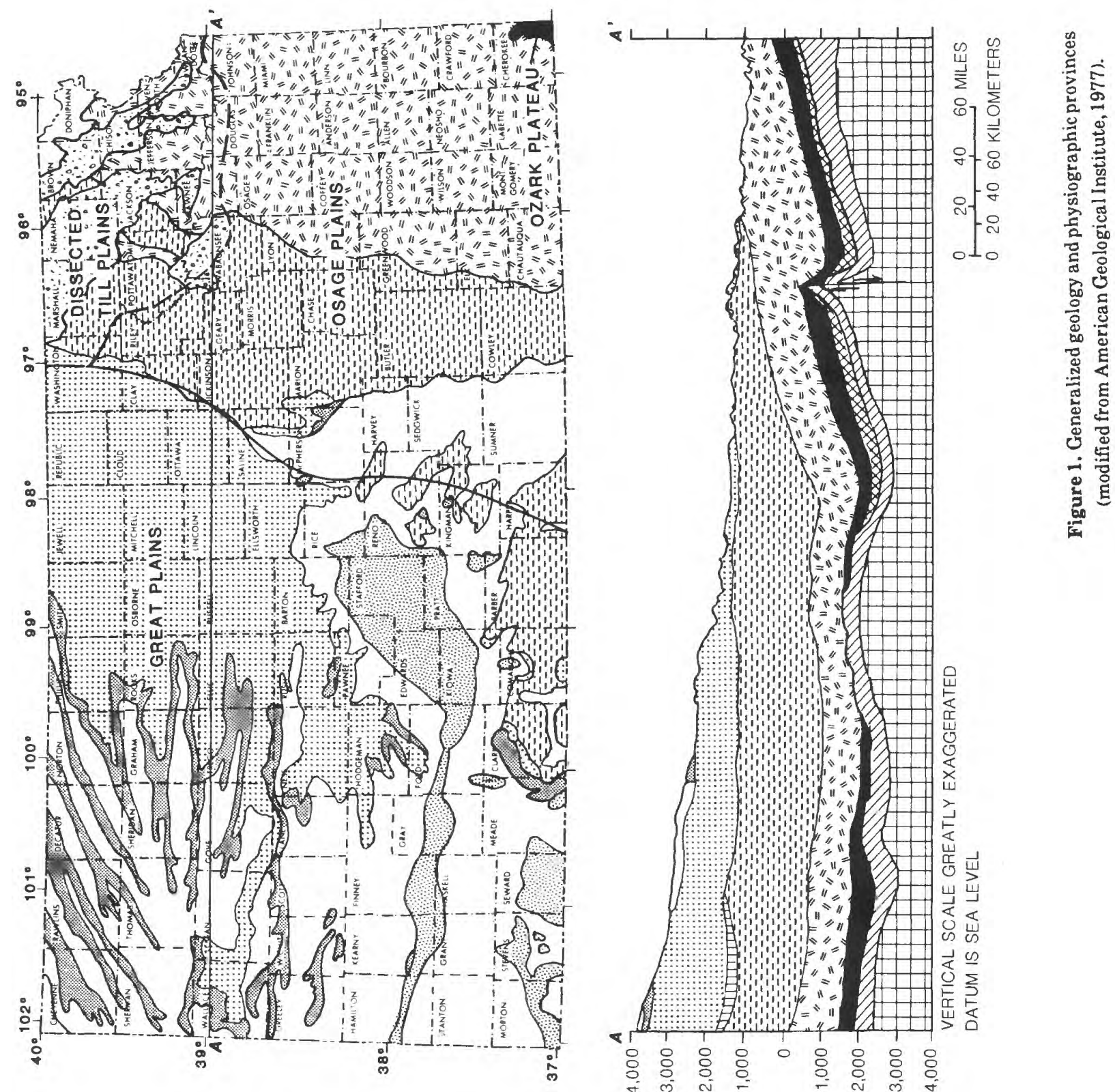
where silt and sand have improved infiltration characteristics of the soil. The northern onefourth of the Osage Plains has been modified by glacial drift of the pre-Illinoian glaciation and by windblown deposits of loess.

The western two-thirds of the State is in the Great Plains physiographic province. Cretaceous rocks with layers of hard limestone characterize the north-central part of the State. Westward, the uplands blend into Tertiary and Quaternary deposits of sand and gravel overlain with windblown loess. The loess soil is somewhat more permeable than the eastern soil and therefore is slightly more susceptible to leaching. The Arkansas River enters Kansas from Colorado and has been responsible for the sand and sand-dune deposits that cover much of south-central Kansas. Soil is permeable in this area, and leaching can be a major soilmanagement problem.

\section{Principal Aquifers}

Principal aquifers in Kansas usually are unconfined and consist of either unconsolidated gravel, sand, silt, and clay, or consolidated sandstone, limestone, and dolomite (fig. 2). The largest alluvial aquifers are associated with the major rivers--the Missouri, Kansas, Arkansas, Republican, and Pawnee Rivers. Wells completed in these aquifers typically yield more than 500 gallons per minute, and static water levels usually are less than 50 feet below land surface. Wells adjacent to the tributaries of these larger rivers commonly yield less than 100 gallons per minute but are still very important as domestic- and municipal-water supplies. Recharge to these alluvial aquifers is mainly from direct infiltration of precipitation and from the stream itself, especially during periods of drought when reservoir releases maintain low flows. Therefore, the streamaquifer boundary can be a pathway by which chemicals in surface runoff enter the groundwater system.

The glacial-drift aquifer is the major source of ground water in the northeast part of the State. This unconfined aquifer consists of sand, gravel, and clay deposited during the preIllinoian glaciation. Most wells in this aquifer yield 10 to 100 gallons per minute, with the most productive wells yielding almost 500 gallons per minute.

The eastern part of the High Plains aquifer consists of the buried valleys of the ancestral Smoky Hill River (Equus beds aquifer) and the Arkansas and Pawnee Rivers (Great Bend Prairie aquifer) (fig. 2). The High Plains aquifer extends westward to the Colorado border. Cenozoic fluvial and eolian deposits of gravel, sand, silt, and clay in the High Plains aquifer yield 500 to 1,500 gallons per minute. This generally unconfined aquifer lies near or at the land surface and is susceptible to contamination by leaching.

The Great Plains aquifer, which generally is unconfined, is formed by the Dakota and Cheyenne Sandstones of Cretaceous age. The use of this aquifer as a water supply extends from Republic and Washington Counties southsouthwestward to Ellsworth County, then westward to eastern Finney County (fig. 2). Wells in the Great Plains aquifer commonly yield 10 to 100 gallons per minute in the northeast part and up to 1,000 gallons per minute in the south and west. Areas where the aquifer crops out are the most susceptible to contamination.

The Chase-Council Grove aquifer in the Chase and Council Grove Groups extends from Riley County to Cowley County and consists of fractured limestone of Permian age. Wells typically yield 10 to 20 gallons per minute. Much of this area is mantled with a thin soil that is best suited for rangeland grazing. However, some chemicals are applied for noxious-weed control on the rangeland and could leach into the aquifer.

The Douglas aquifer in the Douglas Group consists of channel sandstone of Pennsylvanian age that stretches from just west of Kansas City south-southwestward to Chautauqua County (fig. 2). Several cities use this aquifer as a municipal-water supply, especially in the northern outcrop area where it is most susceptible to contamination. Wells yield from 10 to 40 gallons per minute.

The Ozark aquifer is a major source of ground water in the Ozark Plateaus in extreme 

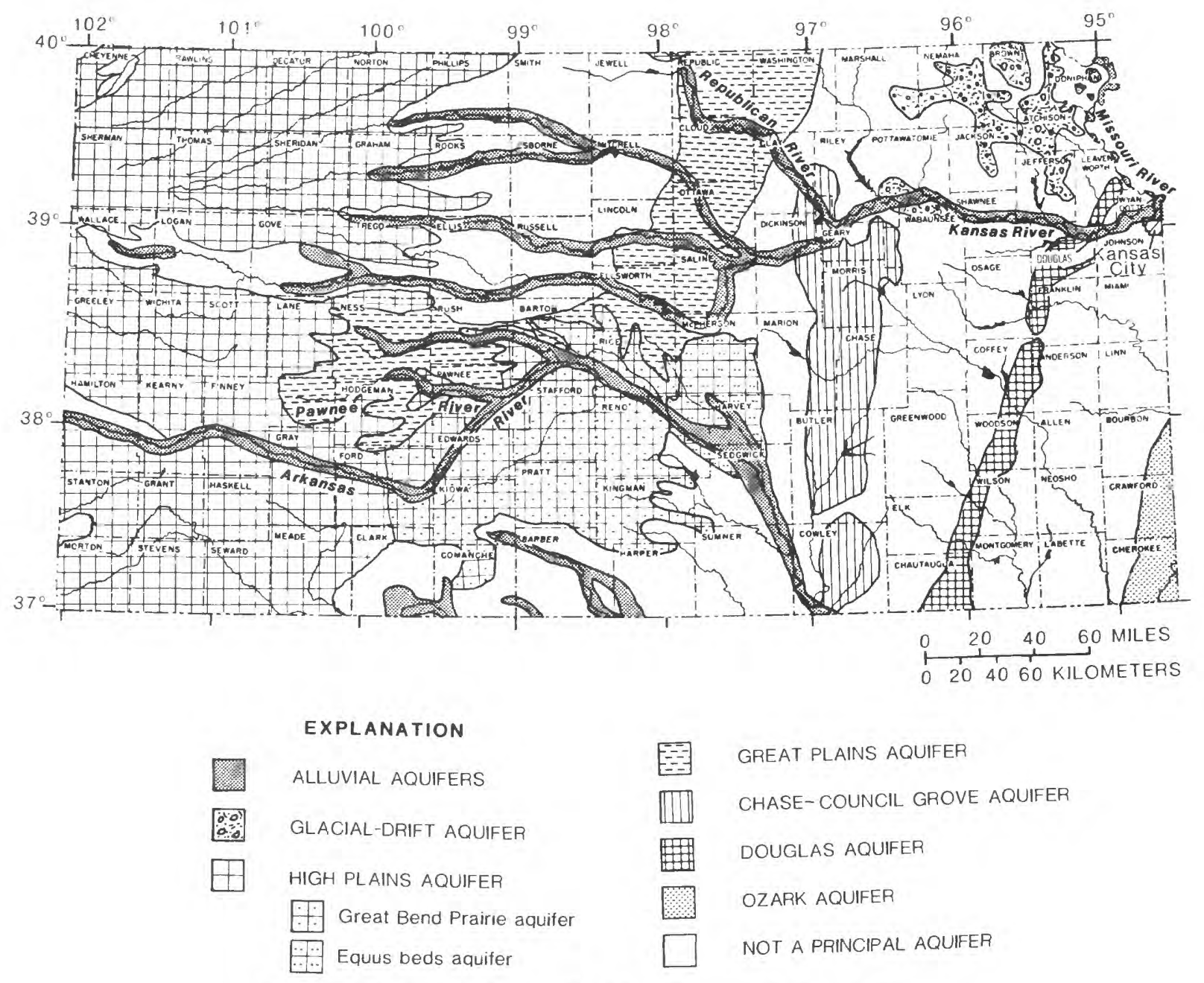

Figure 2. Principal aquifers (modified from Bevans and others, 1985).

southeastern Kansas. This aquifer consists of dolomite of the Arbuckle Group of Cambrian and Ordovician age, which yields 30 to 150 gallons per minute. Depth to the aquifer is greater than 300 feet, and because it is confined, the probability of it being contaminated by agricultural activity is slight.

Many small-yielding domestic wells throughout the State either are dug or drilled into saturated clay, shale, and limestone at locations where there are no major aquifers. These shallow wells are very susceptible to contamination by nitrate and other agricultural chemicals, especially in the eastern part of the State where precipitation is greater.
The climate of Kansas becomes drier going from east to west across the State, as indicated by the map showing average annual precipitation, 1951-80 (fig. 3). The extreme southeastern part of the State receives an average of more than 40 inches of precipitation annually and in many years can be classified as having a humid climate. The western tier of counties averages less than 20 inches of annual precipitation, and in some years can be classified as having an arid climate. Precipitation reports for Kansas are provided by the National Oceanic and Atmospheric Administration for the nine reporting districts indicated in figure 3 . Average annual

\section{Climate}




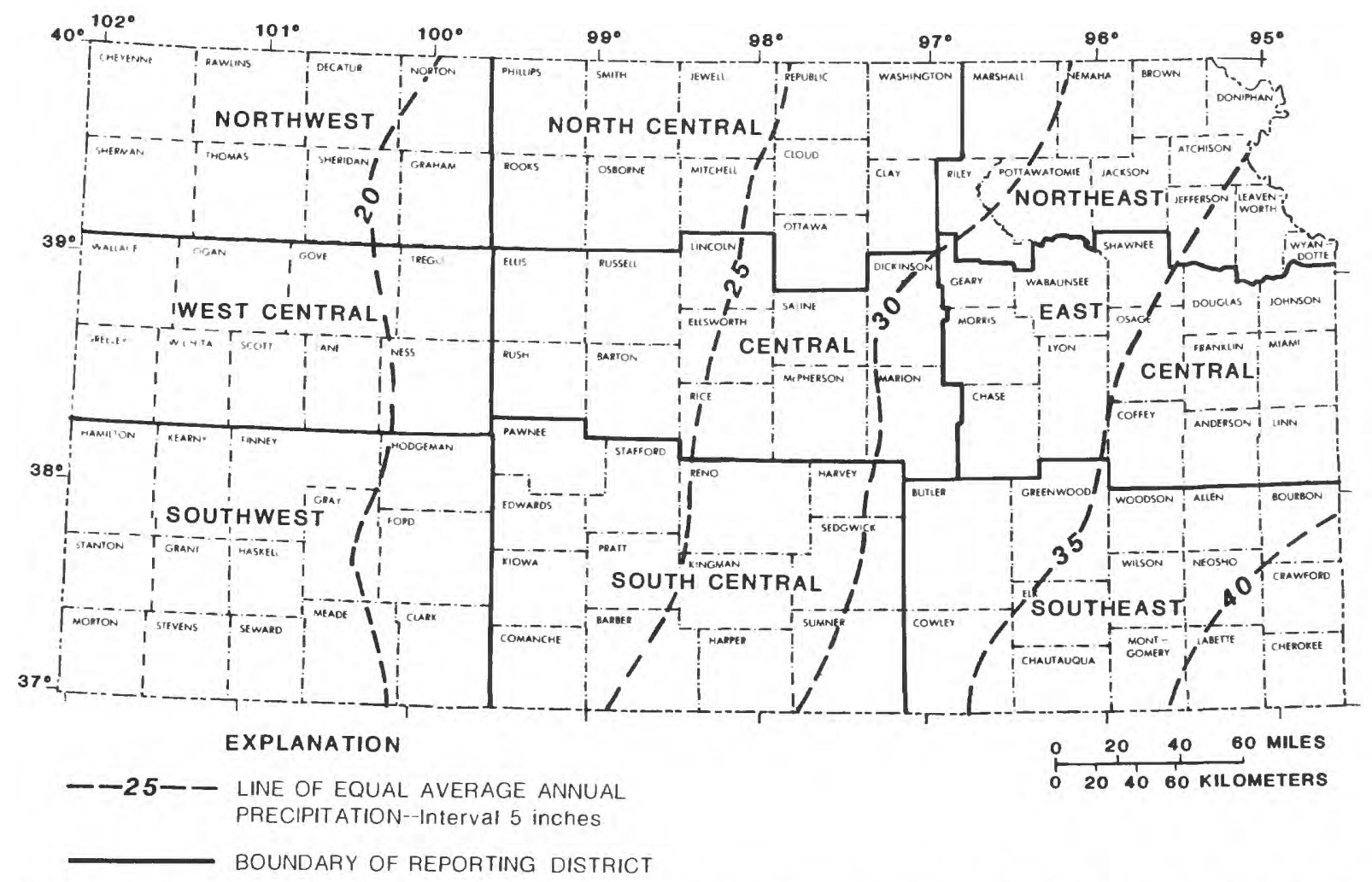

Figure 3. Average annual precipitation, 1951-80, and precipitation reporting districts of the National Oceanic and Atmospheric Adninistration.

Table 1. Average annual precipitation, 1951-80, for nine reporting districts [1)ata from National Oceanic and Atmospheric Administration, 1983]

\begin{tabular}{lc}
\hline \multicolumn{1}{c}{ District } \\
(fig. 3) & $\begin{array}{c}\text { Average annual } \\
\text { precipitation } \\
\text { (inches) }\end{array}$ \\
\hline Northwest & 19.88 \\
North-central & 26.30 \\
Northeast & 34.33 \\
West-central & 19.58 \\
Central & 27.66 \\
East-central & 35.38 \\
Southwest & 18.56 \\
South-central & 26.28 \\
Southeast & 36.50 \\
\hline
\end{tabular}




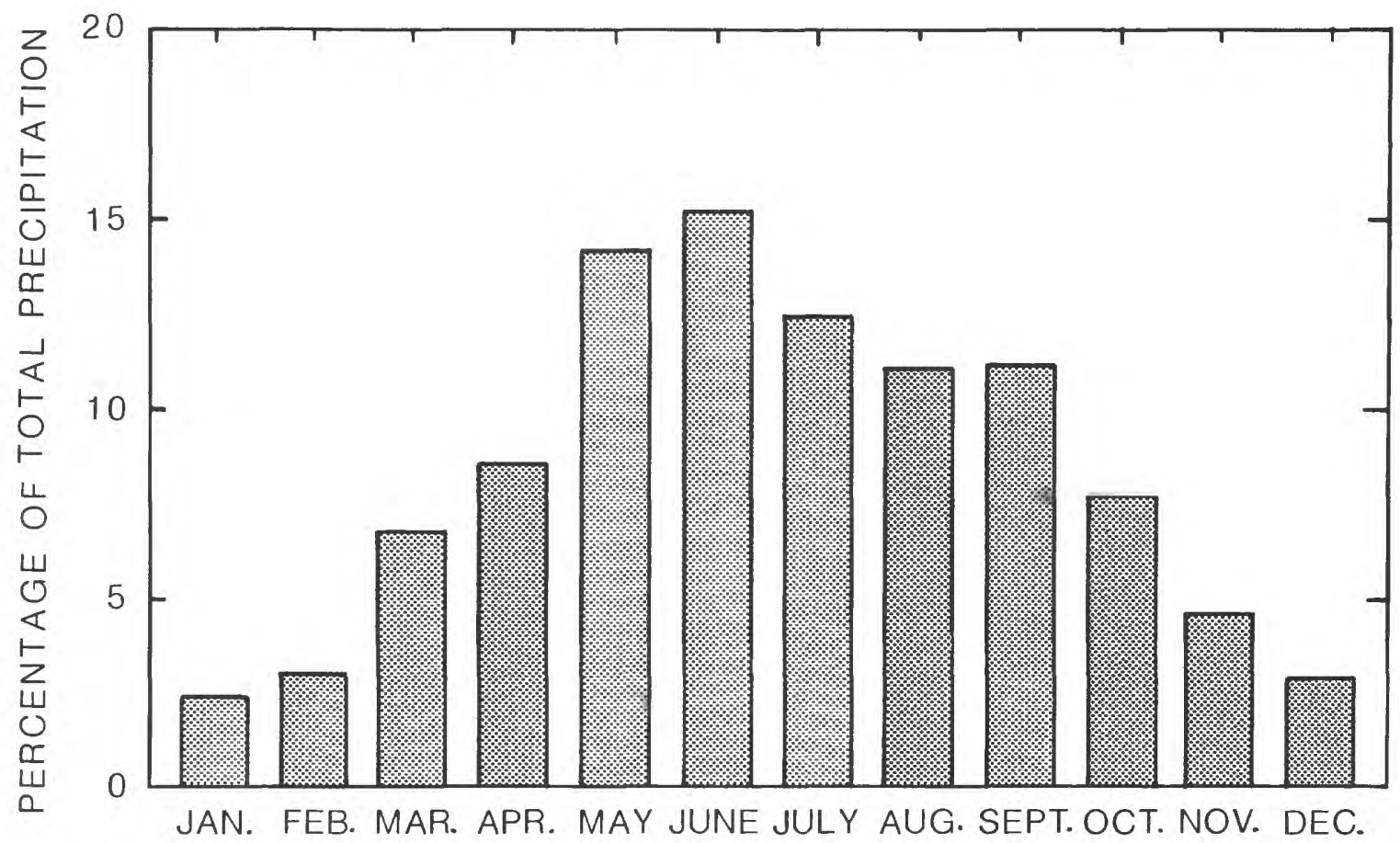

Figure 4. Average monthly precipitation in Kansas as a percentage of total average annual precipitation, 1951-80.

precipitation for these reporting districts is given in table 1 , and figure 4 shows the average monthly precipitation as a percentage of each district's annual average. More than 70 percent of the average annual precipitation occurs during the growing season (April through September). Summers are hot with temperatures in the 90 's and occasionally over $100^{\circ} \mathrm{F}$. Winters usually have extended periods of subfreezing temperatures. Loss of water to the atmosphere (evapotranspiration) is dependent upon temperature, humidity, solar radiation, and the availability and type of live vegetation.

If adequate precipitation is not available, irrigation may be used to supply water for plant growth. The number of irrigated acres for 1984 for the nine reporting districts is shown in table 2. During those periods when rainfall or irrigation rates are greater than the rate of evapotranspiration, a surplus of water occurs, and the soil-moisture reservoir is recharged. If the soil becomes saturated, deep percolation to the ground-water reservoir and (or) runoff occurs. Most generally, deep percolation occurs during the nongrowing season when evapotranspiration is at a minimum, or during excessive application of irrigation water.
The soil of Kansas has developed from various rocks and minerals with different origins. Many of the soil types in the State have developed from underlying geologic formations, which are mainly limestone, shale, and sandstone. Various soil types in northeast Kansas were derived from parent material that was carried into the State by the pre-Illinoian glaciation. Other soil types developed from alluvial deposits along rivers, and some extensive areas are mantled with eolian soil that was imported by the wind.

Soil contains solid mineral particles that are a result of many years of weathering of the parent materials and is mixed with varying amounts of organic material. Soil also contains varying amounts of water and gases. The total volume of the soil is about one-half soil material and one-half pore space (Foth, 1978). This pore space is the channel for movement or storage of soil moisture.

Soil material is divided into three major groups--sand, silt, and clay. These groups or textural classes are based on particle size, as shown in table 3 . A textural classification system developed by the U.S. Department of Agriculture Soil Survey Staff (1951) is shown in figure 5. 
Table 2. Number of irrigated acres in 1984 for nine reporting districts

[Kansas State Board of Agriculture, 1985]

\begin{tabular}{lr}
\hline $\begin{array}{l}\text { District } \\
\text { (fig. 3) }\end{array}$ & $\begin{array}{c}\text { Irrigated land } \\
\text { (acres) }\end{array}$ \\
\hline Northwest & 422,000 \\
North-central & 165,000 \\
Northeast & 25,000 \\
West-central & 350,000 \\
Central & 137,000 \\
East-central & 51,000 \\
Southwest & $1,800,000$ \\
South-central & 479,000 \\
Southeast & 38,000 \\
\hline
\end{tabular}

Soil-moisture characteristics are described as follows. Field capacity is the soil-moisture content after free water has been drained by gravity. Most soil is at field capacity within a few hours to a few days after a rain or irrigation. Soil moisture that is less than field capacity is removed by evaporation or by plant transpiration. As additional water is removed, the force required to remove the water increases until plant roots can no longer withdraw water from the soil. The plant leaves then become permanently wilted. At this point (the permanent wilting point), some water remains in the soil, but it can not be recovered by the plants. The difference in the quantity of water at field capacity and at the permanent wilting point is called available water--soil moisture that is usable for plant growth. The influence of soil texture on field capacity, permanent wilting point, and available soil moisture is shown for three typical soil types in table 4 .

As soil moisture decreases, more force is required to remove water from the soil. The amount of force it takes to remove the water (moisture stress) is also a function of soil

Table 3. Soil-texture classification

[U.S. Department of Agriculture Soil Survey Staff, 1951]

\begin{tabular}{lc}
\hline $\begin{array}{c}\text { Texture } \\
\text { classification }\end{array}$ & $\begin{array}{c}\text { Particle size } \\
\text { (millimeters) }\end{array}$ \\
\hline Stone or gravel & Greater than 2.0 \\
Very coarse sand & $1.0-2.0$ \\
Coarse sand & $0.5-1.0$ \\
Fine sand & $0.10-0.25$ \\
Very fine sand & $0.05-0.10$ \\
Silt & $0.002-0.05$ \\
Clay & Less than 0.002 \\
\hline
\end{tabular}




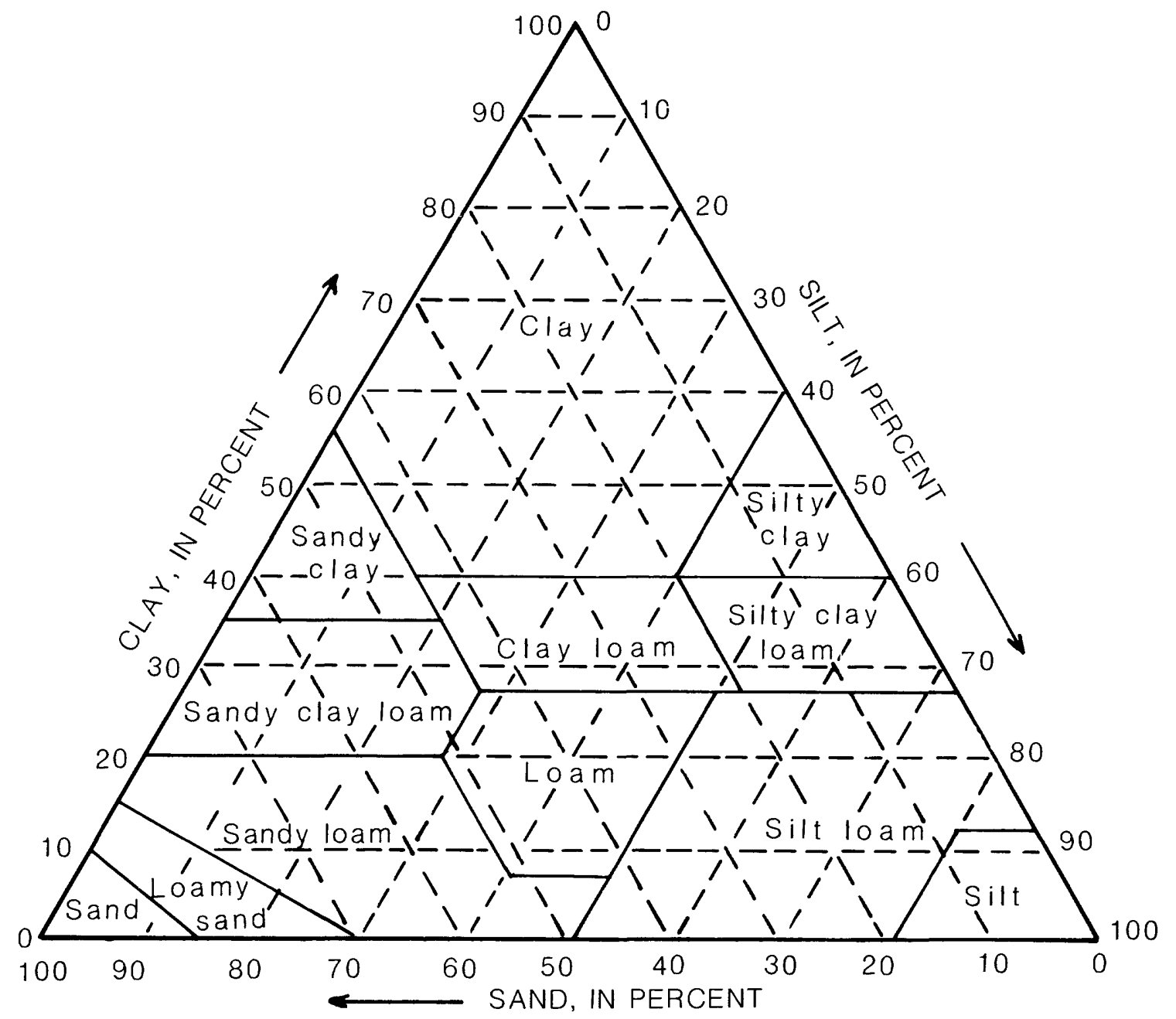

Figure 5. Classification of soil textures (U.S. Department of Agriculture Soil Survey Staff, 1951 ).

Table 4. Typical soil-moisture levels for three soil textures

$\begin{array}{ccc}\text { Texture } & \begin{array}{c}\text { Field capacity } \\ \text { (inches per foot) }\end{array} & \begin{array}{c}\text { Permanent wilting point } \\ \text { (inches per foot) }\end{array} \\ \text { (inches per foot) }\end{array}$

$\begin{array}{lrrr}\text { Sandy } & 1.2 & 0.2 & 1.0 \\ \text { Loamy } & 2.2 & .5 & 1.7 \\ \text { Clay } & 3.6 & 1.2 & 2.4\end{array}$


texture. A set of typical soil-moisture-release curves is shown in figure 6 . Available soil moisture is released more easily from sand than from clay. Although finer textured soil holds more water, it also holds it more tightly than coarser soil. Thus, coarser soil can transmit a much larger quantity of water and chemicals than finer soil. Coarser soil often overlies shallow aquifers, such as those in south-central and southwestern Kansas and in the alluvial river valleys.

Excessive leaching occurs most frequently in coarse-textured soil. If water from rainfall or irrigation is applied to this soil in amounts greater than its field capacity, this water can drain rapidly through the soil and leach any soluble chemicals into the ground water.
Annual moisture used by crops grown in Kansas is shown in table 5.

Coarse-textured soil that is very susceptible to leaching also is most often irrigated. This soil type usually occurs in conjunction with a coarsetextured unsaturated zone and a shallow water table. Water drains easily through sandy soil, thus frequent irrigation is required to maintain the moisture content necessary for crop growth. Excessive irrigation can produce significant chemical leaching losses. Intense rainfall during May through July can cause nitrogenleaching losses from spring-seeded crops. However, intense rainfall does occur at other times of the year and can have an impact on winter-wheat production as well, particularly on coarse-textured soil.

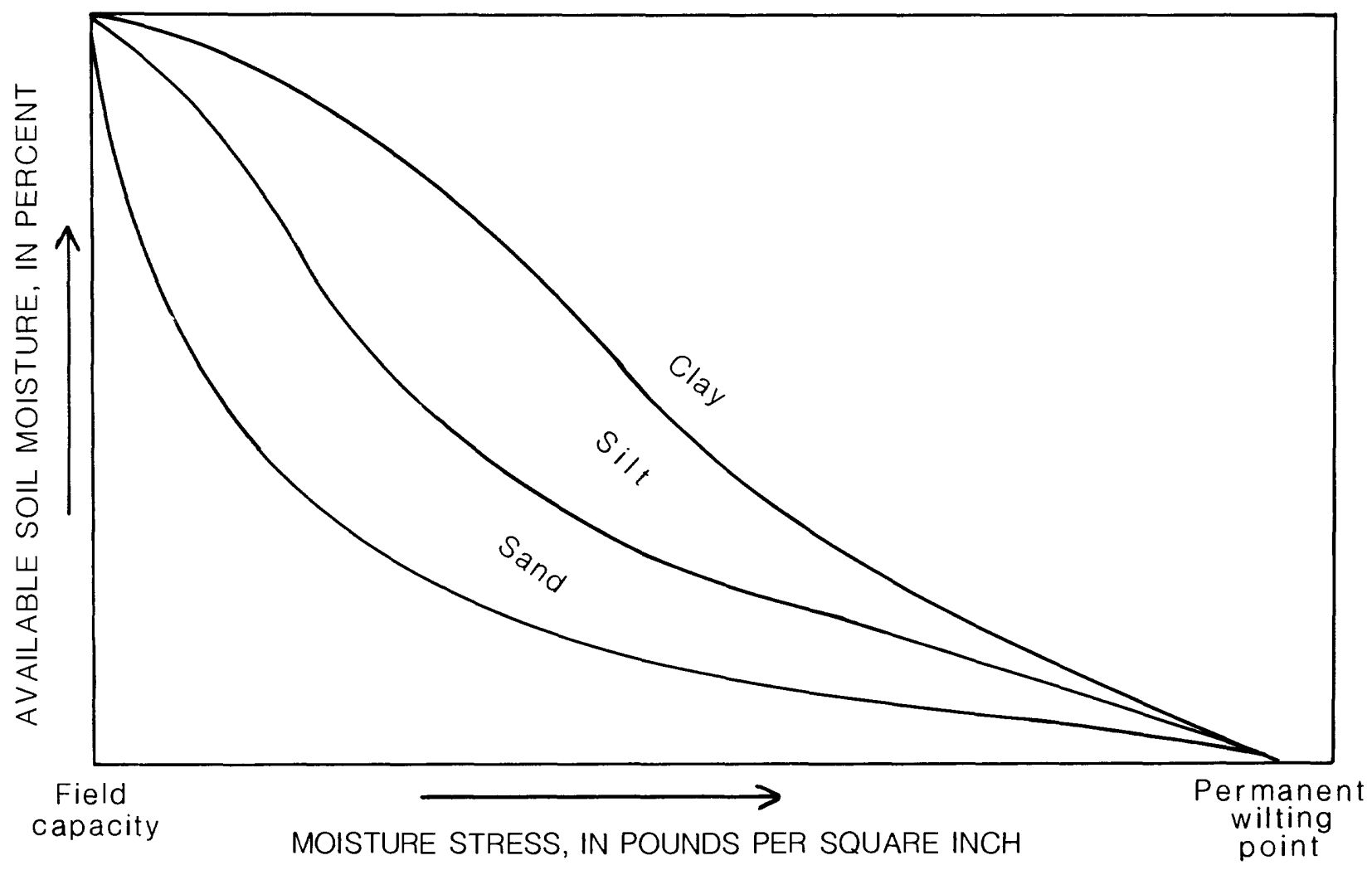

Figure 6. Typical soil-moisture-release curves for three common soil types (Foth, 1978). 
Table 5. Annual crop-moisture use for typical Kansas crops

[Kansas State University, 1982]

\begin{tabular}{lc}
\hline Crop & $\begin{array}{c}\text { Moisture use } \\
\text { (inches) }\end{array}$ \\
\hline Corn & $24-26$ \\
Soybeans & $20-22$ \\
Grain sorghum & $18-20$ \\
Wheat & $15-18$ \\
\hline
\end{tabular}

In general, the greater the percentage of sand in the soil the more susceptible it will be to leaching. Soil is grouped into four classes of leachability (Kissel and others, 1982):

Class 1 - Sand, fine sand, coarse sand, and loamy coarse sand, with permeability ranging from 6 to 20 inches per hour.

Class 2 - Loamy fine sand, coarse sandy loam, and sandy loam, with permeability ranging from 2 to 6 inches per hour.

Class 3 - Loam, very fine sandy loam, silt loam, and fine sandy loam, with permeability ranging from 0.6 to 2 inches per hour.

Class 4 - Clay loam, silty clay loam, silty clay, sandy clay, and clay, with permeability less than 0.6 inch per hour.

As soil types differ across the State, leachability classes vary accordingly. A map showing leachability classes of Kansas soil is shown in figure 7 . The entire soil profile was considered in selection of the leachability class for a particular soil type. The finest textured horizon or the most-limiting layer (smallest permeability) becomes the deciding factor in class selection (Kissel and others, 1982). The leachability map shows that the majority of classes 1 and 2 are in south-central or southwestern Kansas. However, important agricultural areas that have class 1 or 2 soil types are located also in the many river valleys throughout the State. Because of the scale of figure 7, this detail could not be shown. The number of acres in each leachability class in Kansas is listed in table 6.

AGRICULTURAL AND CHEMICAL FACTORS AFFECTING GROUNDWATER QUALITY

\section{Agricultural Land Use}

Farmers in Kansas use a variety of agricultural practices that may be important factors affecting the leaching of agricultural chemicals. These practices are related to climate, in general, and specifically to the depth of soil moisture available for plant growth. The eastern one-third of the State has adequate precipitation to grow most crops, whereas the western two-thirds of the State commonly uses supplemental irrigation. In areas where irrigation water is not available, crops must be grown under dryland conditions, completely dependent upon moisture stored in the soil.

The most common crop grown under dryland conditions in Kansas is winter wheat. Fall preparation for planting wheat involves tillage to reduce plant residues on the soil surface and preparation of the soil seedbed. Fertilizers, herbicides, and insecticides typically are applied before planting. Farmers often increase soilfertility levels by surface or near-surface applications of fertilizer early in the spring. If 


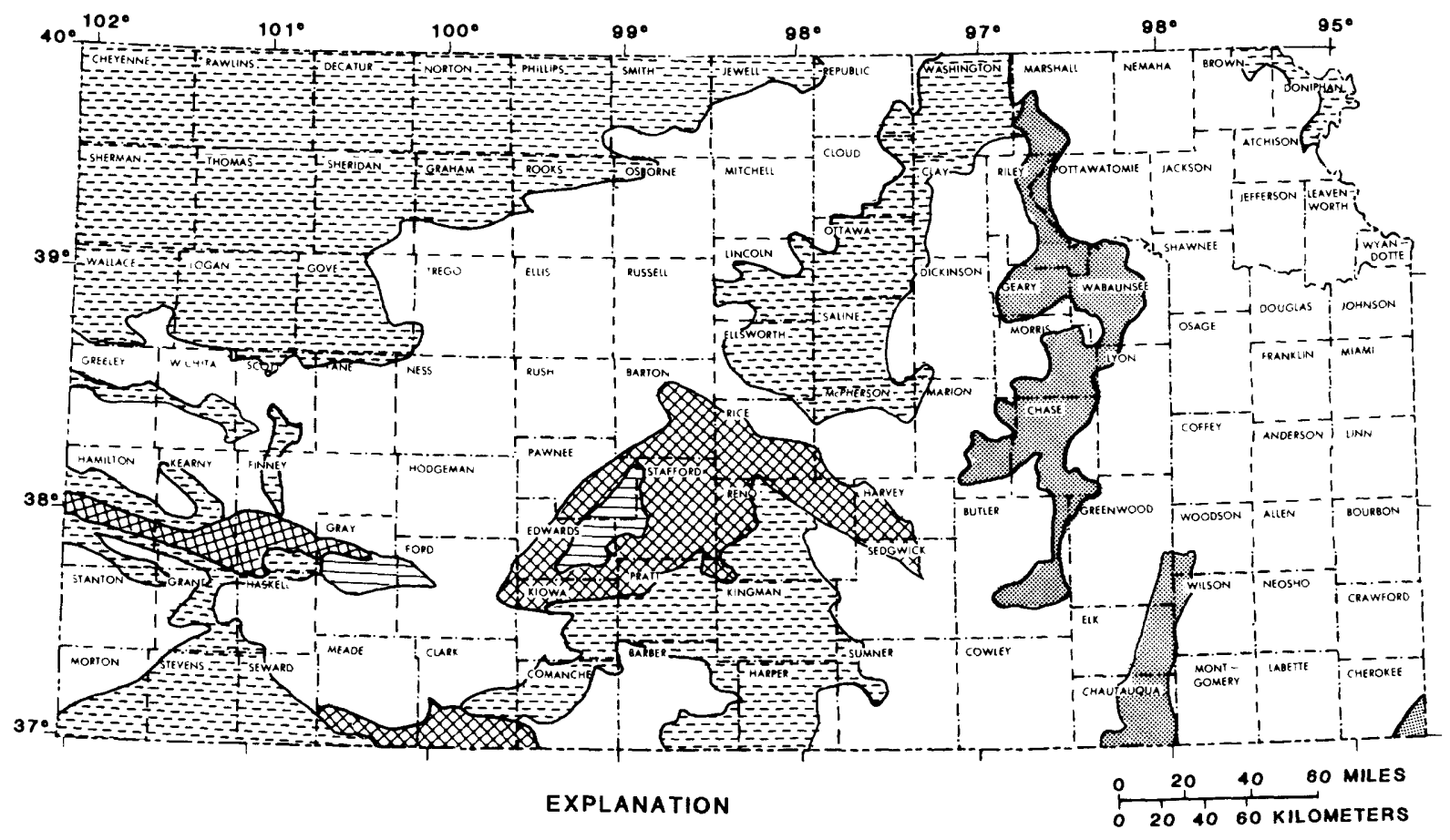

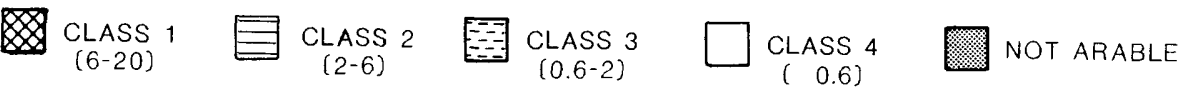

Figure 7. Distribution of leachability classes of Kansas soil (modified from Kissel and others, 1982).

Table 6. Number of acres in each leachability class in Kansas [Kissel and others, 1982]

Class 1

Class 2

Class 3

Class 4
$1,210,000$

$1,770,000$

$12,500,000$

$15,500,000$ 
weed or insect problems occur during the early spring months, additional herbicide or insecticide applications may be necessary. Wheat is harvested during the early summer months, and the soil is allowed to lie idle until preparation for planting is started in the fall.

For areas of the State with adequate precipitation or irrigation, intensive agricultural practices are used to grow row crops, such as corn, grain sorghum, and soybeans. Typically, the preparation of fields is started after the soil has thawed in the spring. Fields are tilled by disking to loosen the soil, and large quantities of nitrogen-containing fertilizers are applied. A short time before planting, herbicides and insecticides are applied and tilled into the soil surface. Further weed growth may require cultivation or application of a postemergent herbicide to the crop. Harvesting of row crops occurs during the late summer and fall. After harvest, crop residues left in the field are disked into the soil. Crop residues are incorporated into the soil by a chisel or plow in the fall, and the soil-residue mixture is allowed to accumulate winter moisture until the next spring. The freezing and thawing process breaks up soil particles and crop residue so that by planting time in the spring a fairly homogeneous mixture of soil and organic material exists.

\section{Agricultural Chemical Use}

\section{Fertilizers}

For centuries crop production has been improved by the addition of natural substances, such as manures, lime, marl, ashes, and bone, to the soil. Certain plants, called legumes, that utilize nitrogen-fixing bacteria were grown periodically to add nitrogen to the soil. With the advent of mechanized farming, much more land was placed in production, and natural fertilizers could not keep pace with crop production. As a result, nutrient depletion and soil erosion occurred. Crop production increased significantly with the commercial production of synthetic fertilizers because growth was limited only by the ability of the plant to absorb the fertilizers and by available moisture. Nutrients from abundant crop residues, combined with excessively applied fertilizers, can accumulate in ponds, rivers, lakes, and ground water. H. D.
Foth (1978) estimated that industrially fixed nitrogen equals natural worldwide terrestrial fixation and that the biosphere is gaining about 9 million metric tons more nitrogen than it is losing. Large concentrations of nitrogen in ground water can be a result of intensive agricultural activity.

Any organic or inorganic substance of natural or synthetic origin that supplies one or more of the nutrient elements essential for the growth and reproduction of plants can be considered a fertilizer. Generally, these substances contain nitrogen, phosphorus, or potassium. The common commercial fertilizers containing nitrogen, phosphot us, or potassium are listed in table 7. Other nutrient elements and chemical radicals combined within a fertilizer also can affect water quality, depending on the soil's chemical characteristics.

Nitrogen--Of the three major fertilizer compounds (nitrogen, phosphorus, or potassium), nitrogen compounds are by far the most extensively used chemicals. Because nitrogen compounds form nitrates that are water soluble, any excess that is not utilized by the growing plants is available for leaching. Leached nitrogen is an economic loss for the farmer, and a potential contaminant to the ground-water system. The farmer must solve the problem of maintaining maximum yields while minimizing nitrogen loss by leaching. The amount of nitrogen leached is a function of soil properties (including chemical and biological factors), amount of water available for leaching, the amount of nitrogen available in the soil, and of course, the composition and properties of the fertilizer. Excessive rates of nitrogen application lead to dissolved nitrogen in the nitrate form $\left(\mathrm{NO}_{3}{ }^{-}\right)$, which is the form of nitrogen most readily used by plants and is one of the most common contaminants indentified in ground water (Freeze and Cherry, 1979).

Several methods of reducing nitrogen leaching are available. These include time and method of fertilizer application, application rates, management of irrigation, and application of nitrogen-release inhibitors; however, all methods are affected by unpredictable weather fluctuations. 
Table 7. Common fertilizers and their chemical formulas

[Love, 1979]

\begin{tabular}{lll}
\hline Fertilizer & \multicolumn{1}{c}{ Material } & Chemical formula \\
\hline Nitrogen & Anhydrous ammonia & NH3 \\
Do. & Urea & CO(NH2)2 \\
Do. & Ammonium nitrate & NH4NO3 \\
Do. & Ammonium sulfate & (NH4)2SO4 \\
Do. & Diammonium phosphate & (NH4)2HPO4 \\
Do. & Sodium nitrate & NaNO3 \\
Do. & Potassium nitrate & KNO3 \\
Phosphorus & Rock phosphate & Ca10F2(PO4)6 \\
Do. & Concentrated superphosphate & Ca(H2PO4)2 \\
Do. & Phosphoric acid & H3PO4 \\
Do. & Diammonium phosphate & (NH4)2HPO4 \\
Potassium & Muriate of potash & KCl \\
Do. & Sulfate of potash & K2SO4 \\
Do. & Potassium nitrate & KNO3 \\
Do. & Potassium metaphosphate & KPO3 \\
\hline
\end{tabular}

Research conducted at Kansas State University, Manhattan, Kans. (Kissel and Virgil, 1985), has shown that varying the timing and method of nitrogen application has consistently given good results (table 8 ). The application of nitrogen fertilizer closer to the time that it is actually needed by the crop can reduce nitrogen losses. Two or three smaller surface applications (postemergence) of nitrogen that can be used by the crop within 3 weeks is preferable to a large single application. The additional costs of extra trips across the field can be offset by savings on nitrogen. However, field compaction by equipment used for the extra trips can retard plant growth. This method reduces the amount of fertilizer available to leach through the soil profile with excess precipitation. Incorporation of fertilizer broadcast on the surface into the top layer of soil by disking is recommended where feasible. This method reduces the chance for movement by surface runoff or volatilization loss.

Nitrogen application rates vary across the State, depending on crop, soil, and precipitation. Rates of nitrogen application recommended by the Kansas Cooperative Extension Service are listed in table 9 (Whitney, 1976).

Irrigation water can be applied at a rate that will minimize deep percolation. This can be done by irrigating more often at a slower rate with a sprinkler system or by surge flooding. Surge flooding utilizes pulses of water in a furrow instead of continuous flow. The objective of the surge-flooding method is to keep the moisture content of the wetted soil profile just below field capacity, slow the downward percolation of water, and keep the nitrogen where the plants can utilize it.

The use of nitrification inhibitors as a nitrogen management tool has increased in recent years. Inhibitors are used to slow the conversion of ammonium $\left(\mathrm{NH}_{4}{ }^{+}\right)$to the nitrate $\left(\mathrm{NO}_{3}{ }^{-}\right)$form of nitrogen that can be utilized by plants. Nitrification inhibitors that have been tested in Kansas are as follows:

1. Carbon disulfide,

2. Sodium trithiocarbonate, 
Table 8. Nitrogen application rates for alternative timing of application

[Modified from Kissel and Virgil (1985). Values are in percent of total nitrogen applied]

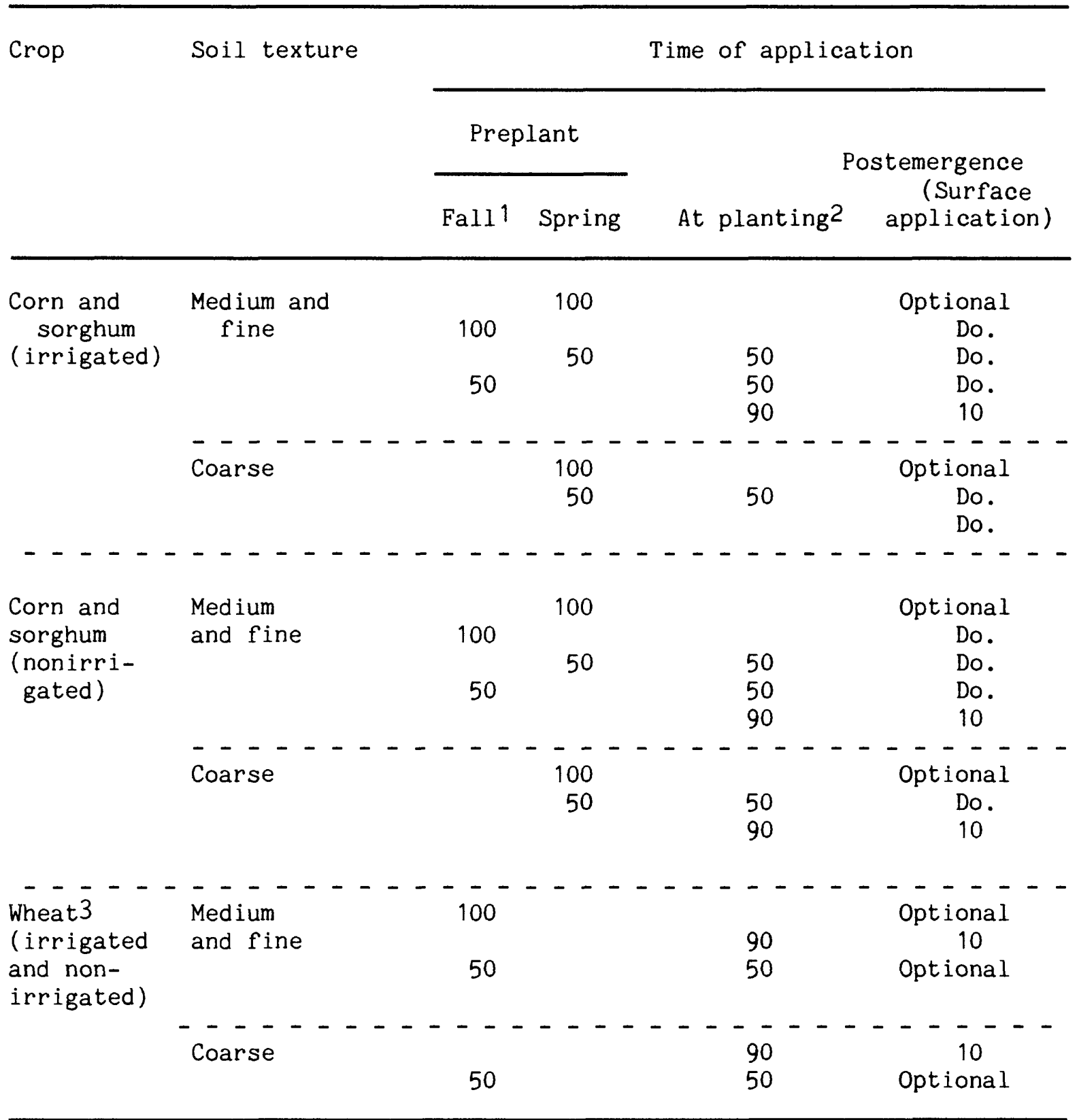

1 Fall preplant applications should not be made on soils subject to flooding or soils that are poorly drained and stay extremely wet most springs.

2 Base the use on the need for phosphorus as a starter.

3 Preplant applications on wheat may result in excessive fall growth unless wheat is pastured or seeding delayed. Surface applications should be made before March 15. 
Table 9. Nitrogen application rates recommended by Kansas Cooperative Extension Service for different locations and crops

[Data from Whitney, 1976. Values in pounds per acre]

\begin{tabular}{|c|c|c|c|c|c|}
\hline \multirow[b]{2}{*}{ Crop } & \multirow[b]{2}{*}{$\begin{array}{l}\text { Area of } \\
\text { State }\end{array}$} & \multicolumn{2}{|c|}{$\begin{array}{l}\text { Medium- and fine- } \\
\text { textured soils }\end{array}$} & \multicolumn{2}{|c|}{$\begin{array}{l}\text { Sandy-textured } \\
\text { soil }\end{array}$} \\
\hline & & Fallowed & $\begin{array}{l}\text { Continuous } \\
\text { cropped }\end{array}$ & Dryland & Irrigated \\
\hline Corn 1 & Entire & & $100-200$ & $100-200$ & $160-220$ \\
\hline Sorghum & $\begin{array}{l}\text { Eastern } \\
\text { Central } \\
\text { Western2 }\end{array}$ & $\begin{array}{r}30-60 \\
0-40\end{array}$ & $\begin{array}{l}80-160 \\
40-80\end{array}$ & $\begin{array}{l}80-160 \\
40-80 \\
30-40\end{array}$ & $\begin{array}{l}120-180 \\
120-180 \\
120-180\end{array}$ \\
\hline Wheat3 & $\begin{array}{l}\text { Eastern } \\
\text { Central } \\
\text { Western2 }\end{array}$ & $\begin{array}{r}20-40 \\
0-40\end{array}$ & $\begin{array}{l}40-70 \\
30-60\end{array}$ & $\begin{array}{l}40-70 \\
40-60 \\
25-50\end{array}$ & $\begin{array}{l}50-80 \\
50-80 \\
50-80\end{array}$ \\
\hline Soybeans & Entire & None & None & None & None \\
\hline
\end{tabular}

1 These recommendations are for both grain and silage production. Dryland corn is not recommended in central and western Kansas.

2 Recommendations are based on sufficient subsoil moisture at planting time. If subsoil moisture is insufficient at planting time, then nitrogen application rates shown for western Kansas under dryland conditions should be reduced.

3 If wheat is pastured extensively, then add 2 to 30 pounds per acre to nitrogen recommendations.

3. Ammonium dithiocarbamate,

4. Potassium ethyl xanthate, and

5. 2-chloro-6-(trichloromethyl)-pyridine (nitrapyrin).

Of these products, the first four were not effective in inhibiting nitrification under the conditions that existed at the locations where they were applied. Nitrapyrin was effective in inhibiting nitrification in all studies (Maddux and others, 1985). Nitrapyrin was best at inhibiting nitrification on coarse-textured soil where leaching can be significant. Tests have shown inhibition of nitrification for periods of 4 to 6 weeks (Barnes and others, 1982; 1983). Nitrapyrin retards the growth of bacteria that produce nitrate, allows a more efficient use of nitrogen fertilizer for plant growth, and effectively reduces nitrate concentrations available for leaching into ground water. Nitrapyrin can be used as a deterrent to leaching from unexpected excess precipitation and to extend the interval between fractional fertilizer applications.

Phosphorus and Potassium--Phosphorus and potassium have very limited movement in the soil and virtually remain in the area of application. For row crops 
and small grains, phosphorus and potassium generally are incorporated into the seedbed prior to planting or applied at planting. With reduced-tillage practices being used on many farms, the application of phosphorus and potassium can create problems. For these nutrients to be effectively utilized by row crops and small grains, they must be incorporated into the root zone. With no-till practices, the phosphorus and potassium may be supplied at planting or incorporated in large quantities every 2 to 3 years.

Phosphorus and potassium application rates usually are based on soil tests that determine the background concentrations for these constituents. For soils that are deficient in phosphorus, application rates vary from 20 pounds per acre for western dryland wheat to 80 pounds per acre for irrigated corn and grain sorghum used for silage. Potassium application rates range from 20 to 140 pounds per acre for soil that is deficient in potassium.

Lime--Lime (primarily calcium carbonate, but may contain magnesium carbonate) is used to treat soil that is acidic. The type of lime to use, whether calcic $\left(\mathrm{CaCO}_{3}\right)$ or dolomitic $\left(\mathrm{MgCO}_{3}\right)$, is determined by the calcium-magnesium balance in the soil when the initial $\mathrm{pH}$ determinations are made. Soil $\mathrm{pH}$ is a measure of soil acidity (less than $\mathrm{pH}$ 7) or alkalinity (greater than $\mathrm{pH}$ 7) and is used to determine the need for the application of lime, which helps to neutralize acidic soil and increase crop production. The amount of lime needed is determined by the use of a buffer solution applied to a soil sample. The a mount of lime required depends on factors, such as amount and type of clay, organic matter, and soluble aluminum content in the soil. Effective neutralization of soil acidity depends on thorough mixing of the lime with the soil. An application of the recommended rate of lime may be sufficient to maintain a satisfactory soil $\mathrm{pH}$ for several years. Additional lime needs should be determined by regular testing of the soil every 3 years.

lncreased crop production on irrigated sandy soil in south-central and western Kansas frequently has resulted in soil $\mathrm{pH}$ values of less than 7 . These small $\mathrm{pH}$ values may be the result of excessive nitrogen applications; 1 pound of ammonium nitrate may require as much as 6 pounds of lime to prevent an increase in acidity and to maintain optimum conditions for nitrification. Small pII values also may be the result of increased organic content from crop residues and soil leaching. Solubility and leaching of many chemicals in the soil vary according to the $\mathrm{pH}$ of the soil water.

\section{Pesticides}

A major survey of pesticide usage in Kansas was conducted in 1978 by the Cooperative Extension Service at Kansas State University and the Kansas Crop and Livestock Reporting Service (Nilson and Johnson, 1980). Information was collected in two separate surveys, one for crops and another for pasture and rangeland. Farmers were asked to report acreage and specific pesticide treatments for each crop and land use. Approximately 12,000 farmers, farming a total of nearly 2 million acres, responded to the survey. The reported data were extrapolated using the estimated crop acreage in the nine reporting districts (fig. 3) to determine area and statewide application of specific pesticides. The extrapolated area treated with each pesticide then was multiplied by the label-recommended rate of application to determine the estimated quantity of active ingredient applied. The 1978 pesticide-usage values are summarized in table 10 . Table 18 in the "Supplemental Information" section at the end of this report lists pesticide usage by reporting district.

During 1978, Kansas farmers applied approximately 28.1 million pounds of active pesticide ingredients. Herbicides accounted for 85 percent of the total ( 23.8 million pounds) and insecticides for 15 percent $(4.3$ million pounds). Approximately 10 million acres were treated with herbicide at an average rate of 2.4 pounds per acre, and 4 million acres were treated with insecticides at a rate of 1 pound per acre. More than 30 percent of the 20 million acres in crops received herbicides, with a total of 18.3 million pounds applied. The remaining 5.5 million pounds of herbicides were applied to 2.6 million acres (12 percent) of pasture and rangeland. All the insecticides were applied to cropland, with 
Table 10.--Pesticide usage on crops and pasture or rangeland in Kansas, 1978

[Data from Nilson and Johnson, 1980]

\begin{tabular}{|c|c|c|c|c|c|}
\hline $\begin{array}{l}\text { Pesticide } \\
\text { class }\end{array}$ & Common name & Trade name & $\begin{array}{c}\text { Area applied } 1 \\
\text { (acre) }\end{array}$ & $\begin{array}{l}\text { Percent- } \\
\text { age } \\
\text { of crop }\end{array}$ & $\begin{array}{ll}\text { Mean } & \text { Total } \\
\text { rate } & \text { applied } \\
\text { (pounds } & \text { (pounds) } \\
\text { per acre) } & \end{array}$ \\
\hline
\end{tabular}

\section{Corn}

\section{Herbicides}

\begin{tabular}{ll} 
Atrazine & \multicolumn{1}{c}{--} \\
EPTC & AAtrex \\
Butylate & Eradicane \\
Alachlor & Sutan+ \\
Cyanazine & Lasso \\
& Bladex
\end{tabular}

Propachlor

$2,4-D^{2}$

Metolachlor

Dicamba

Pend imethal in

Glyphosate

Insecticides

Carbofuran
Terbufos
Fonofos
Phorate
Carbaryl

Heptachlor

Propargite

Parathion3

Toxaphene

Oxydemetonmethyl Metasystox-R

Disulfoton
Di-Syston

$1,559,900$
$1,392,600$
349,000
290,300
300,800
143,300
48,700
69,400
12,800
29,800
4,600
1,600

Roundup

Furadan

Counter

Dyfonate

Thimet

Sevin

$1,479,800$

387,100

330,800

323,500

294,800

130,100

103,300

110,900

168,800

32,500

146,600

69,000

$\begin{array}{cc}86 & 3.97 \\ 77 & 1.63 \\ 19 & 4.25 \\ 16 & 4.50 \\ 17 & 2.02 \\ 7.8 & 1.91\end{array}$

$6,185,800$

$2,266,000$

$1,482,000$

$1,305,000$

606,400

273,100

\section{$2.7 \quad 3.55$}

$3.8 \quad .45$

$.70 \quad 2.16$

1.6

.34

$.25 \quad 1.30$

$.09 \quad 3.50$

81

1.53

172,900

31,200

27,600

10,000

6,000

5,600

21

18

1.00

1.00

1.00

18

1.07

$\begin{array}{ll}7.1 & 2.34\end{array}$

$2,268,300$

$\begin{array}{ll}5.7 & 2.00 \\ 6.1 & 1.67\end{array}$

--

$1.8 \quad 2.91$

$8.1 \quad .57$

$3.8 \quad 1.00$

390,300

330,800

323,500

314,300

304,700

206,600

185,200

94,700

83,600

69,000

\section{Grain sorghum}

Herbicides

Ramrod
AAtrex
Milogard
Igran
Bladex

$3,249,600$

$1,074,000$

$2,079,400$

651,500

381,300

611,100

94,300
69

23

44

14

8.1

13

2.0
2.76

3.36

1.66

1.32

1.75

.44

1.24
$8,983,400$

$3,607,600$

$3,448,000$

857,600

666,000

268,700

117,300 
Table 10. Pesticide usage on crops and pasture or rangeland in Kansas, 1978--Continued

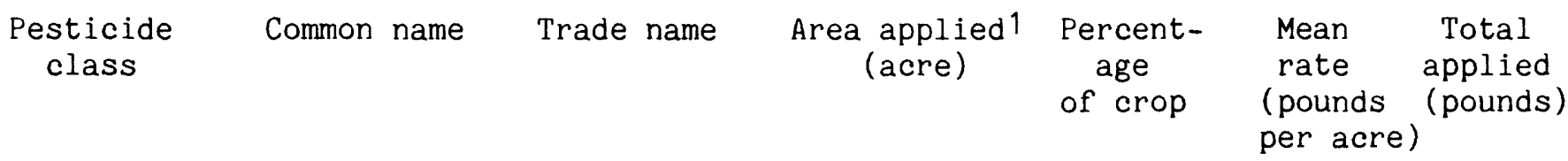

Herbicides

\section{Grain sorghum--Continued}

$$
\begin{aligned}
& \text { Glyphosate } \\
& \text { Dicamba }
\end{aligned}
$$

Insecticides

Disulfoton

Carbary 1

Phorate

Parathion3

Carbofuran

Malathion

Heptachlor

Dimethoate

Lindane

Oxydemetonmethy 1 Metasystox- $R$

Demeton
Roundup
Banvel

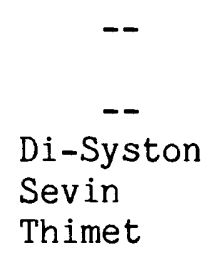

Furadan

Cygon

--
Toxaphene

$$
\begin{array}{r}
2,700 \\
34,700 \\
1,862,600 \\
112,000 \\
380,400 \\
126,600 \\
188,800 \\
270,800 \\
129,800 \\
35,200 \\
731,000 \\
16,500 \\
64,000 \\
7,300 \\
4,100
\end{array}
$$

Wheat

Herbicides

$$
\begin{aligned}
& 2,4-\mathrm{D}^{2} \\
& \text { Dicamba } \\
& \text { Bromoxynil }
\end{aligned}
$$

\section{Banvel}

Brominal

Insecticides

Toxaphene

Heptachlor

Parathion3

Malathion

Lindane

Endosulfan

Carbary 1

Endrin

Dimethoate

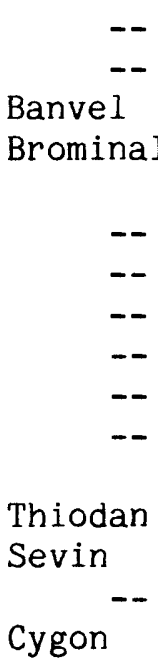

$1,085,700$
$1,024,200$
124,000
23,000

516,000

74,900

239,800

17,900

7,300

78,600

6,700

2,000

1,400

1,000

$\begin{array}{rr}0.05 & 3.50 \\ .74 & .25\end{array}$

9,500

8,700

40

.81

$1,515,500$

2.4

3.35

375,400

8.1

.96

2.7

2.03

4.0

1.00

5.8

.51

364,200

257,500

188,800

138,500

$\begin{array}{cc}2.8 & .82 \\ 16 & 1.19 \\ .35 & .04 \\ 1.4 & .33 \\ & .04\end{array}$

106,900

42,000

30,700

5,500

2,700

$.16 \quad .33$

2,400

.09

1,000

$\begin{array}{rrr}10 & .61 & 665,900 \\ 9.1 & .63 & 641,700 \\ 1.1 & .13 & 15,500 \\ .21 & .38 & 8,700\end{array}$

$\begin{array}{lll}5.0 & .72 & 372,700\end{array}$

$\begin{array}{lll}.66 & 4.40 & 330,200\end{array}$

$\begin{array}{lll}2.1 & .06 & 14,400\end{array}$

$\begin{array}{lll}.16 & .50 & 8,950\end{array}$

$\begin{array}{lll}.06 & 1.00 & 7,300\end{array}$

$\begin{array}{lll}.70 & .06 & 4,700\end{array}$

$\begin{array}{rrr}.06 & .50 & 3,350 \\ .02 & 1.50 & 3,000 \\ .01 & .25 & 350 \\ .01 & .42 & 400\end{array}$ 
Table 10. Pesticide usage on crops and pasture or rangeland in Kansas, 1978--Continued

\begin{tabular}{|c|c|c|c|c|c|c|}
\hline $\begin{array}{c}\text { Pesticide } \\
\text { class }\end{array}$ & Common name & Trade name & $\begin{array}{c}\text { Area applied } 1 \\
\text { (acre) }\end{array}$ & $\begin{array}{l}\text { Percent- } \\
\text { age } \\
\text { of crop }\end{array}$ & $\begin{array}{l}\text { Mean } \\
\text { rate } \\
\text { (pounds } \\
\text { per acre }\end{array}$ & $\begin{array}{l}\text { Total } \\
\text { applied } \\
\text { (pounds) }\end{array}$ \\
\hline
\end{tabular}

\section{Soybeans}

Herbicides

Insecticides

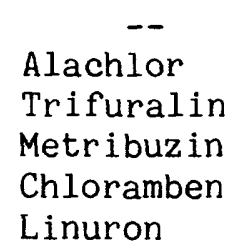

$\begin{array}{ll}\text { Bentazon } & \text { Basagran } \\ \text { Pendimethalin } & \text { Prowl } \\ \text { Profluralin } & \text { Tolban } \\ \text { Oryzalin } & \text { Surflan } \\ \text { Bifenox } & \text { Modown }\end{array}$

Naptalam

Dinoseb

Glyphosate

Fluchloral in

Dinitroamine

\section{Alanap \\ -- \\ Roundup \\ Basal in \\ Cobex}

\section{Toxaphene}

Carbaryl

Parathion3

Malathion

Dimethoate

$\begin{array}{rr}1,161,400 & 78 \\ 404,900 & 27 \\ 551,200 & 37 \\ 449,600 & 30 \\ 53,300 & 3 \\ 92,900 & 6.3\end{array}$

, 900

67,600

38,500

43,700

50,800

22,600

9,800

1,200

1,800

1,600

30,800

15,300

2,800

6,600

2,200

1,200

$\begin{array}{ccc}78 & 1.94 & 2,255,600 \\ 27 & 2.29 & 925,200 \\ 37 & 1.25 & 691,000 \\ 30 & .43 & 193,300 \\ 3.6 & 2.00 & 106,600 \\ 6.3 & 1.00 & 92,900\end{array}$

4.6

2.6

3.0

3.4

1.5

1.00

1.11

.87

.72

1.45

.66

2.25

$--$

.08

.12

.11

2.0

1.0

.19

.45

.15

.08
$--$

3.50

1.00

.50

1.45

2.05

2.24

.50

1.13

1.00
67,600

42,900

37,900

36,600

32,800

22, 000

$--$

4,200

1,800

800

44,700

31,400

6,300

3,300

2,500

1,200

\section{Alfalfa}

Herbicides

\begin{tabular}{ll}
\multicolumn{1}{c}{$\quad$} & \multicolumn{1}{c}{--} \\
Simazin & Princep \\
Propham & Chem-Hoe \\
EPTC & Eptam \\
Profluralin & Tolban \\
Benefin & Balan \\
Diuron & Karmex \\
Terbacil & Sinbar \\
2,4-DB & Butyrac
\end{tabular}

59,100

6.0

1.52

90,000

38,400

7,600

3.7

.72

1.20

46,100

1,900

3.50

.11

.80

26,600

4,700

1.00

960

.45

1.13

4,700

3,000

.29

3,400

1,800

.17

1.60

.80

2, 900

600

1.00

.11

960

600 
Table 10. Pesticide usage on crops and pasture or rangeland in Kansas, 1978--Continued

\begin{tabular}{|c|c|c|c|c|c|}
\hline $\begin{array}{c}\text { Pesticide } \\
\text { class }\end{array}$ & Common name & Trade name & $\begin{array}{c}\text { Area applied } 1 \\
\text { (acre) }\end{array}$ & $\begin{array}{l}\text { Percent- } \\
\text { age } \\
\text { of crop }\end{array}$ & $\begin{array}{ll}\text { Mean } & \text { Total } \\
\text { rate } & \text { applied } \\
\text { (pounds } & \text { (pounds) } \\
\text { per acre) } & \end{array}$ \\
\hline
\end{tabular}

\section{Alfalfa--Continued}

Insecticides

Carbofuran

Malathion

Parathion3

Methoxychlor

Methidation

Azinophosmethyl Guthion

Dimethoate

Diazinon

Phosmet

Trichlorfon

Furadan
--
--
Supracide
Guthion
Cygon
Imidan
Dylox

139,500

57,800

16,500

34,500

4,900

7,900

4,200

4, 900

3,200

1,900

800
13

5.5

1.6

3.3

.5

.8

.4

.5

.3

.2

.08
0.71

.49

1.38

.51

1.17

.50

.75

.53

.70

1.0

1.0
99,000

28,200

22,800

17,500

5,700

3,950

3,150

2,600

2, 200

1,900

800

Pasture and rangeland

Herbicides

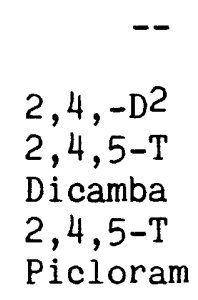

$2,581,900$

12

$2.135,505,800$

$2,4,-D^{2}$

$2,4,5-T$

Dicamba

Picloram

Banvel
Silvex
Tordon

$2,306,700$
719,800

11

29,800

24,200

600

1.69

$3,906,700$

3.4

2.07

$1,488,700$

.14

2.00

59,600

.11

2.00

48,500

4.00

2,400

\section{Fallow}

Herbicides

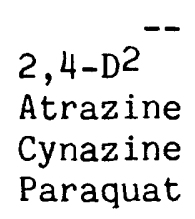

3.00

1.9

1.00

.07

.04
.79

.64

1.00

2.40

.25
167,300

86,400

67,700

12,500

1 The "area applied" includes acres where a pesticide is used alone or in combination. A given area may receive multiple pesticides; therefore, the sum of individual chemicals does not equal the total area of application for the category.

2 Includes ester and amine formulations.

3 Includes both ethyl and methyl parathion and encapsulated forms. 
20 percent of the planted acreage receiving treatment.

In terms of total quantity, atrazine was the most extensively used pesticide, with 5.8 million pounds applied. However, in areal extent, 2,4-D was used most extensively, being applied to more than 4 million acres. The most popular herbicide for application to pasture and rangeland was 2,4-D, while atrazine was used extensively on corn and grain sorghum. No insecticide approached the level of usage of the major herbicides in either areal extent or quantity. During 1978, seven herbicides were applied in quantities exceeding 1 million pounds, but no insecticide application exceeded 1 million pounds.

A few selected herbicides and insecticides accounted for the vast majority of usage. Thirtyfive different herbicides were used, but the top 10 in usage accounted for 94 percent of the total quantity applied. Twenty-three insecticides were used, but the 10 most used accounted for more than 99 percent of the total quantity applied.

Knowledge of crops grown in a given area can give a good indication of the pesticides used and the approximate quantities used. Pesticides were used to the greatest extent on corn. Eightysix percent of all corn acreage received herbicides, and 81 percent received insecticides. Each acre of corn treated for weed control received an average application of nearly 4 pounds of herbicides compared to the average of all crops of 2.4 pounds per acre. However, the largest total quantity of pesticides was applied to grain sorghum. Pesticides were utilized least on wheat, with only 10 percent of the planted acreage treated for weed control and 5 percent for insect control. For each crop, typically four or five herbicides and insecticides accounted for the majority of treated acreage. In the case of wheat, fallow, and pasture and rangeland, 2,4-D was applied to 89 percent of the acreage treated for weed control.

The 1978 survey of pesticide usage (Nilson and Johnson, 1980) also provided herbicide data compiled by reporting districts (fig. 3 ). Comparable data on insecticide usage were not compiled. Usage of major herbicides is presented for each of the nine reporting districts in table 18 in the section on "Supplemental Information." Only 8 to 10 herbicides are tabulated for each district, but in each case those tabulated represented more than 90 percent of total herbicide usage in the district.

In the three western reporting districts, atrazine dominated herbicide usage in terms of both acreage and total quantity applied. Across western Kansas, herbicides for corn production were in greatest use during 1978. Atrazine was applied to about 80 percent of all corn acreage in western Kansas, with the largest percentage in northwest Kansas (89 percent). Atrazine also was applied to approximately 30 percent of western Kansas grain-sorghum acreage. EP'TC was used on about 25 percent of the corn acreage in western Kansas, and propazine was applied to about 25 percent of the grain sorghum. Alachlor was applied to 25 percent of all corn acreage in northwest Kansas, but is was not used extensively in the remainder of western Kansas.

A significant difference between the western and the central reporting districts was the predominance of 2,4-D use in the central reporting districts. Corn was not a major crop in central Kansas, and the considerable use of 2,4$\mathrm{D}$ on grain sorghum, wheat, and especially pastureland, made it surpass atrazine in both acreage and total quantity applied throughout central Kansas. Atrazine was the primary herbicide used on corn and grain sorghum in central Kansas, but propachlor also was used extensively on grain sorghum. Alachlor was used more extensively in central Kansas than in western Kansas. Herbicides were utilized to a much greater extent in north-central Kansas than in the remainder of central Kansas. In fact, total herbicide usage in north-central reporting districts nearly equaled the combined totals of the central and south-central districts.

The character of herbicide usage in eastern Kansas differs somewhat from the rest of the State, due primarily to cropping patterns. Soybeans were a major crop in eastern Kansas, and herbicide usage included trifluralin, metribuzin, and alachlor, which are used primarily or exclusively on soybeans. Atrazine and 2,4-D were the most extensively used herbicides in eastern Kansas, with usage of these two chemicals nearly equal in each of the three eastern reporting districts. Atrazine was 
applied to approximately three-fourths of the acreage planted to both corn and grain sorghum; whereas 2,4-D was used primarily on grassland and to some extent on corn, grain sorghum, and wheat. Throughout eastern Kansas, propachlor was the third most-used herbicide, and alachlor was fourth. Propachlor was applied to approximately 40 percent of grain-sorghum acreage, and alachlor was used on 25 to 30 percent of both corn and grain-sorghum acreage. It is important to note that in eastern Kansas, as in central Kansas, the northernmost reporting district relied the most on herbicides. Northeast Kansas was the only reporting district in which any single herbicide was applied in excess of 1 million pounds. In northeast Kansas, 2,4-D, atrazine, and propachlor were all used in quantities exceeding 1 million pounds.

Overall, the three eastern reporting districts, plus north-central Kansas, had the greatest reliance on herbicides during 1978. Herbicide usage in these four areas, which encompass approximately 40 percent of the agricultural land in Kansas, was at least 60 percent of the statewide total. This greater dependence on herbicides is due primarily to differences in cropping patterns and climate. It is important to note that the districts reporting significant herbicide usage also have shallow and very vulnerable ground-water supplies.

Total pesticide usage in the State increased only slightly since 1978 , based on a comparison of major crop acreages for 1978 and 1984, the latest year of published crop-production statistics (Kansas State Board of Agriculture, 1985). Major crop acreages, total and irrigated for 1978 and 1984, are listed in table 11. The total acreage planted to the four major crops (corn, grain sorghum, wheat, and soybeans) increased by 8 percent, slightly over 1.5 million acres. Much of this added acreage came from placing marginal land into production, which could require additional herbicides. The greatest increase was the additional 2 million acres for wheat, an 18-percent increase. The mean rate of herbicide application to wheat was 0.61 pound per acre for insecticides, 0.72 pound per acre. Both rates were the smallest application rates for any of the major crops. Soybean acreage increased 14 percent, up
210,000 acres, and grain sorghum increased slightly. The largest change was the total acreage planted to corn, which decreased by 40 percent, 770,000 acres, with more than one-half of that total decrease in irrigated acreage. This decrease was largely an effect of the conservation of irrigation water in the western two-thirds of the State. Corn had the largest rate of pesticide application of the major crops. However, the increased wheat and soybean acreages (2.2 million acres) offset the decreased corn acreage ( 0.77 million acres) in relation to total weight of pesticides used. A slight decrease in the use of atrazine statewide could be inferred from this analysis. Irrigated wheat acreage increased 125 percent $(522,000$ acres $)$, and irrigated grain-sorghum acreage increased 30 percent $(94,000$ acres). Total irrigated acreage was up 12 percent, an increase of 264,000 acres.

Chemical Properties of Pesticides--The leaching of pesticides in the soil is dependent on the sorptive characteristics of the compound and soil. Sorptive characteristics significantly affect the physical leaching of pesticides within a soilwater matrix. The sorptive properties of pesticides generally correlate well with the organic carbon content of soil, which usually decreases with depth. Sorption of organic solutes from water to soil is related to the aqueous solubility of the solute, with the leastsoluble organic compounds being the most sorbed onto the soil. The adsorption partition coefficient (Kd) can be computed from the organic content of the soil and either the solubility or the octanol-water distribution coefficient by the equations (Carsel and others, 1984):

or

$\log \mathrm{Koc}=3.64-(0.557 \times \log \mathrm{Sol})$,

$\log \mathrm{Koc}=1.00(\log \mathrm{Kow})-0.21$,

and

$\mathrm{Kd}=\mathrm{Koc}$ (percent organic carbon),

where $\mathrm{Koc}=$ organic-carbon distribution coefficient;

Sol = solubility, in milligrams per liter;

and

Kow $=$ octanol-water distribution coefficient. 
Table 11. Total and irrigated crop acreages during 1978 and 1984

\begin{tabular}{|c|c|c|c|c|c|}
\hline \multirow{2}{*}{$\begin{array}{l}\text { Reporting } \\
\text { district } \\
(\mathrm{fig} \cdot 3)\end{array}$} & \multirow[t]{2}{*}{ Crop } & \multicolumn{2}{|c|}{$\begin{array}{c}\text { Total acreage } \\
\text { (thousands of acres) }\end{array}$} & \multicolumn{2}{|c|}{$\begin{array}{c}\text { Irrigated acreage } \\
\text { (thousands of acres) }\end{array}$} \\
\hline & & 19781 & 19842 & 19781 & 19842 \\
\hline \multirow[t]{4}{*}{ Northwest } & Corn & 240 & 133 & 198 & 107 \\
\hline & Sorghum & 107 & 451 & 43 & 82 \\
\hline & Wheat & 1,257 & 1,373 & 21 & 84 \\
\hline & Soybeans & 1 & 47 & $<1$ & $<1$ \\
\hline \multirow[t]{4}{*}{ West-central } & Corn & 190 & 62 & 136 & 46 \\
\hline & Sorghum & 218 & 436 & 58 & 82 \\
\hline & Wheat & 1,348 & 1,456 & 57 & 106 \\
\hline & Soybeans & & 15 & $<1$ & $<1$ \\
\hline \multirow[t]{4}{*}{ Southwest } & Corn & 555 & 313 & 493 & 266 \\
\hline & Sorghum & 783 & 934 & 356 & 415 \\
\hline & Wheat & 2,039 & 2,354 & 297 & 611 \\
\hline & Soybeans & 18 & 70 & $<1$ & $<1$ \\
\hline \multirow[t]{4}{*}{ North-central } & Corn & 111 & 88 & 80 & 71 \\
\hline & Sorghum & 704 & 605 & 18 & 33 \\
\hline & Wheat & 1,334 & 1,543 & 2 & 10 \\
\hline & Soybeans & 34 & 103 & $<1$ & $<1$ \\
\hline \multirow[t]{4}{*}{ Central } & Corn & 62 & 42 & 33 & 23 \\
\hline & Sorghum & 607 & 530 & 42 & 44 \\
\hline & Wheat & 1,727 & 1,793 & 6 & 16 \\
\hline & Soybeans & 37 & 52 & $<1$ & $<1$ \\
\hline \multirow[t]{4}{*}{ South-central } & Corn & 124 & 84 & 102 & 71 \\
\hline & Sorghum & 608 & 634 & 100 & 147 \\
\hline & Wheat & 2,633 & 2,848 & 34 & 112 \\
\hline & Soybeans & 66 & 116 & $<1$ & $<1$ \\
\hline \multirow[t]{4}{*}{ Northeast } & Corn & 268 & 183 & 10 & 10 \\
\hline & Sorghum & 573 & 408 & 3 & 3 \\
\hline & Wheat & 244 & 508 & $<1$ & $<1$ \\
\hline & Soybeans & 295 & 342 & $<1$ & $<1$ \\
\hline \multirow[t]{4}{*}{ East-central } & Corn & 190 & 112 & 17 & 20 \\
\hline & Sorghum & 498 & 440 & 3 & 9 \\
\hline & Wheat & 235 & 533 & $<1$ & $<1$ \\
\hline & Soybeans & 513 & 434 & $<1$ & $<1$ \\
\hline \multirow[t]{4}{*}{ Southeast } & Corn & 80 & 33 & 2 & 5 \\
\hline & Sorghum & 502 & 362 & 5 & 7 \\
\hline & Wheat & 483 & 892 & $<1$ & $<1$ \\
\hline & Soybeans & 552 & 551 & $<1$ & $<1$ \\
\hline
\end{tabular}


Table 11. Total and irrigated crop acreages during 1978 and 1984--Continued

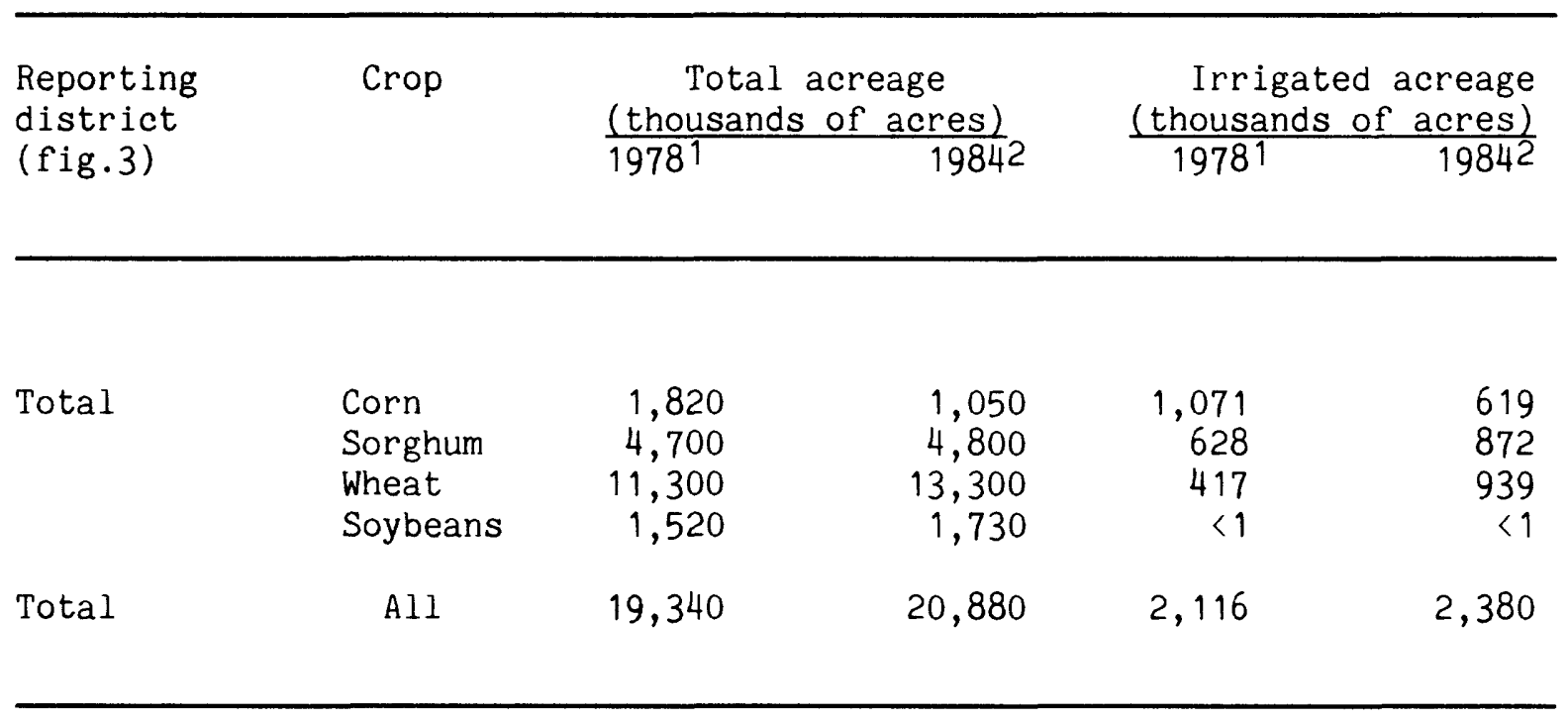

1 Kansas State Board of Agriculture, 1980.

2 Kansas State Board of Agriculture, 1985.

Table 12 is a compilation of available data on solubility, octanol-water distribution coefficient, half-life, and acute oral toxicity $\left(\mathrm{LD}_{50}\right)$ for selected pesticides. Pesticides detected in Kansas ground water are labeled with footnote 3 . Half-life of a pesticide is the time that expires until the mass becomes onehalf of the mass of the initial parent compound by chemical degradation. The parent compound may decompose into other organic compounds, which have different chemical properties. Halflife is quite variable and is dependent on soil $\mathrm{pH}$, soil moisture, temperature, microbial activity, and sunlight. Toxicity can be expressed as the $\mathrm{LD}_{50}$, which is a statistical estimate of the acute oral dosage necessary to kill 50 percent of a large population of laboratory animals under stated conditions. The smaller the $\mathrm{LD}_{50}$, the more toxic the chemical.

Pesticide-Soil Interactions--Pesticides have complex interactions with soil and other environmental factors. Atrazine, the most commonly used pesticide in Kansas, has been chosen to exemplify the variety of possible pathways for leaching and degradation. Atrazine is a selective herbicide for use on a variety of crops, orchards, and ornamental and terrestrial noncrop and forestry sites. Atrazine is applied by using ground-spray equipment, aircraft, or center-pivot irrigation systems. Many studies involving atrazine have been conducted to investigate degradation rates in various soil types under different conditions, the metabolites generated by degradation, and the leaching and mobility of the parent substance. These various degradation factors for atrazine vary according to soil type, $\mathrm{pH}$, temperature, moisture levels, light conditions, microbial activity, and whether the soil/water system is aerobic or anaerobic.

Under aerobic conditions, 38 percent of the applied atrazine degraded to hydroxy-atrazine in sandy load, 40 percent in silty clay loam, and 47 percent in silty loam after 8 weeks at $30^{\circ} \mathrm{C}$ (Harris, 1967). Atrazine labeled with carbon-14 is moderately to significantly mobine in soil ranging in texture from gravelly sand to clay, as 


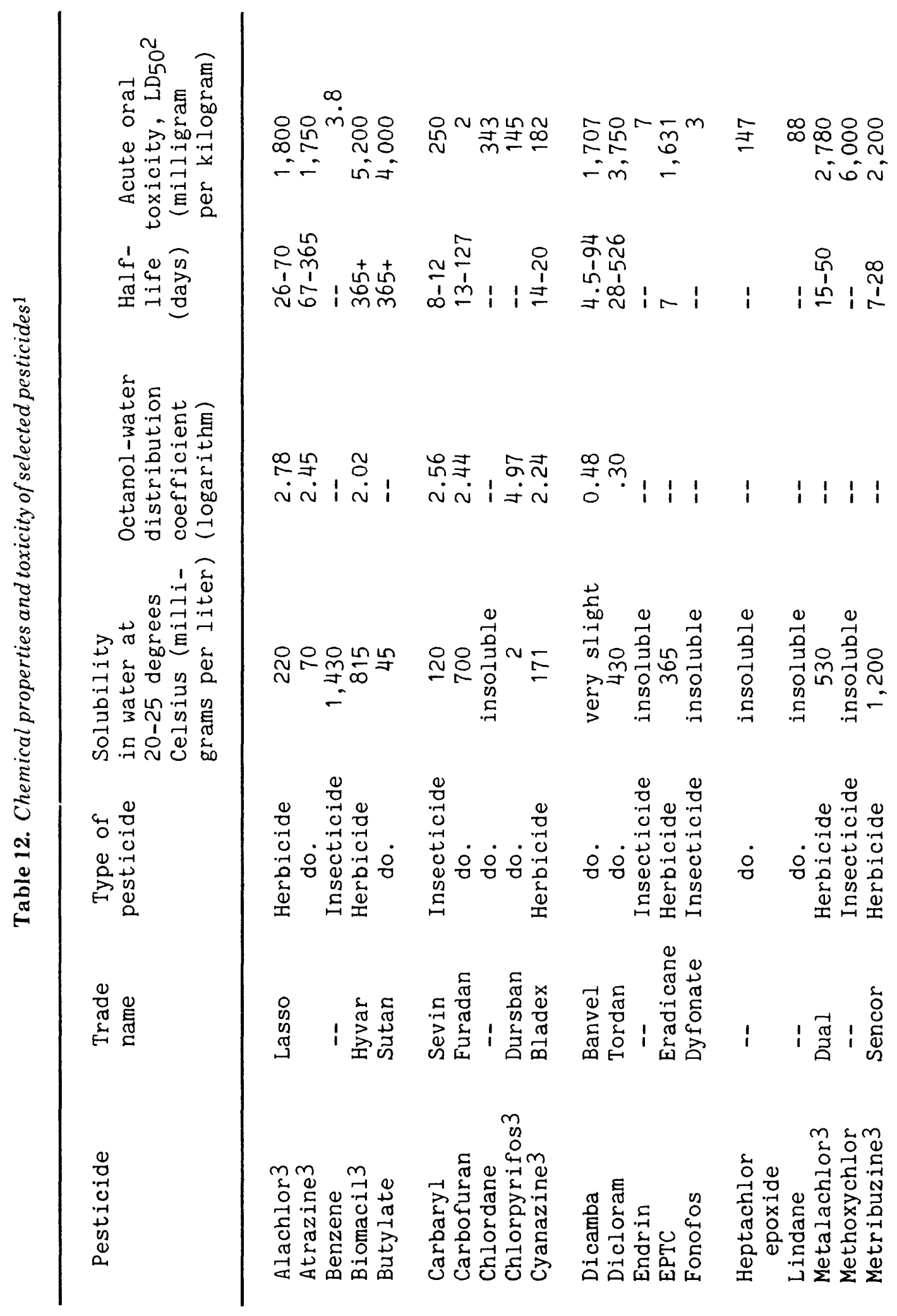




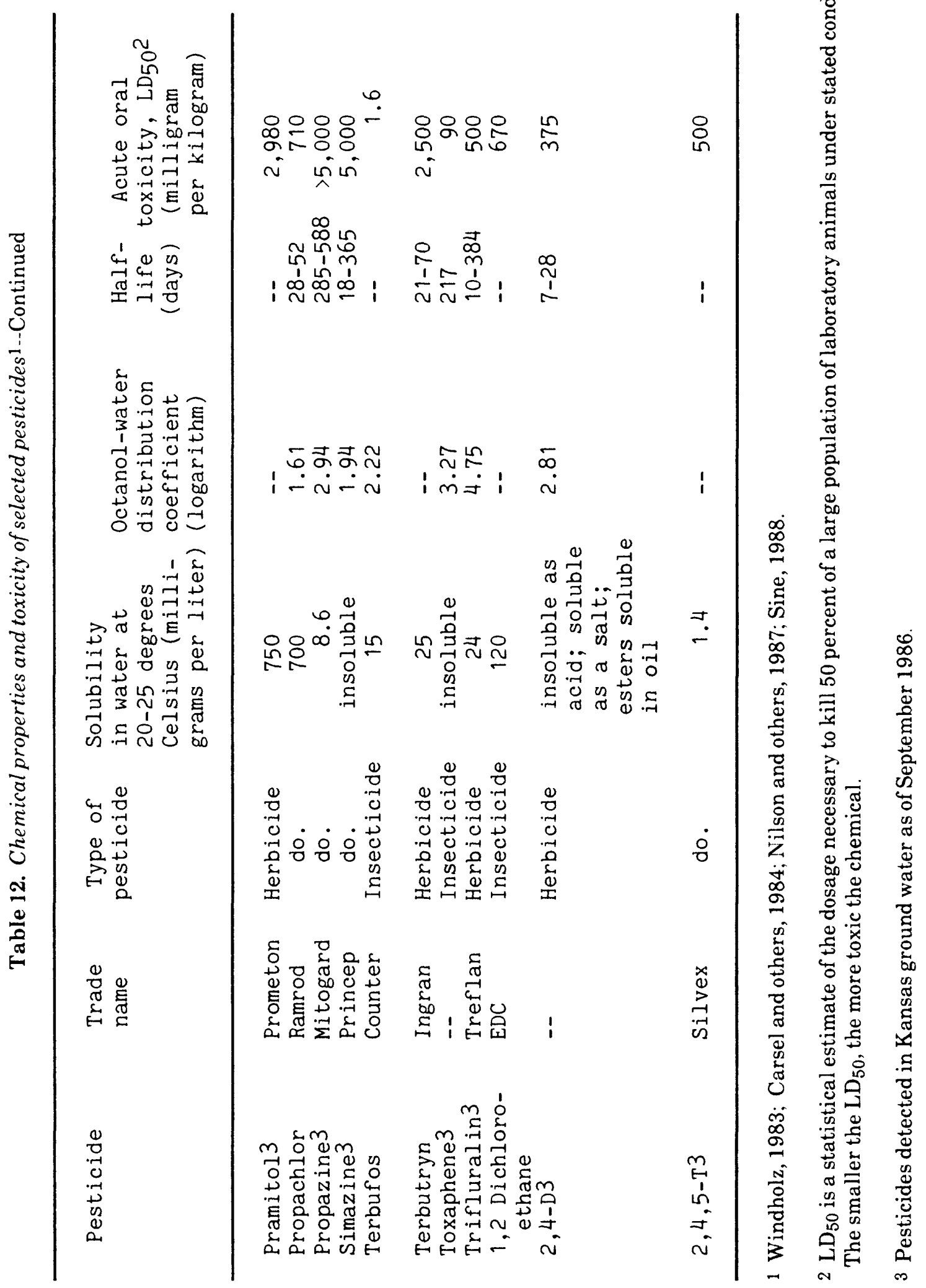


determined by soil thin-layer chromatography, column leaching, and adsorption/desorption batch equilibrium tests. Based on soil thin-layer chromatography tests, atrazine was intermediately mobine in loam, sandy-clay loam, silty loam, silty-clay loam, and silty-clay soils, and mobile in sandy-loam soil; while the degradation hydroxy-atrazine had little mobility in sandy loam and silty-clay-loam soil (Helling, 1971). Rapid adsorption and desorption of atrazine in a clay-loam soil were determined to be affected markedly by soil $\mathrm{pH}$ within the range of 3.9 to 8.0 but were not affected appreciably by temperature changes within the range of 10 to $40{ }^{\circ} \mathrm{C}$ (McCormick and Hilbold, 1966). Atrazine degraded in sandy soil at $23^{\circ} \mathrm{C}$, with a half-life of more than 125 days at 4 -percent water-holding capacity, 37 days at 35 percent water-holding capacity, and 36 days at 70 percent waterholding capacity (Hurl and Kibler, 1976). Atrazine undergoes rapid photodegradation in water with a half-life of approximately 25 hours (Burkhard and Guth, 1976). Atrazine was stable in aerobic ground-water samples incubated for 15 months at 10 or $25^{\circ} \mathrm{C}$ in the dark (Weidner, 1974). Phytotoxic residues of atrazine persisted for more than 24 weeks at $10^{\circ} \mathrm{C}$ and for less than 12 weeks at $35^{\circ} \mathrm{C}$ (Lavy, 1974).

The combination of degradation factors can make the prediction of the leaching and fate of atrazine quite complex. The half-life increases as the sand content increases and as soil temperature decreases. Sunlight enhances the degradation of atrazine. Therefore, atrazine applied to minimal or no-tillage agricultural plots may be slower to degrade than plots that are tilleci. Greater moisture content in the soil aids in degradation of the chemical, but once atrazine reaches the water table, it appears to be more stable.

The increased stability of atrazine in a saturated environment may be related to decreased oxygen concentration, decreased organic carbon concent, low stable temperature, and decreased microbial activity. The leaching of atrazine in the soil is related to soil type and $\mathrm{pH}$. Soil type includes particle size, cationexchange characteristics of the clay portion, and organic carbon content. Development of humic acids or lime application can alter soil $\mathrm{pH}$ substantially from year to year.
Because it is a polar molecule, the metabolite hydroxy-atrazine has chemical properties that are quite different from atrazine. This is true for most of the other pesticides and their metabolites. Each chemical has unique properties that affect leaching and fate.

\section{DRINKING-WATER STANDARDS}

The quality of public drinking water in Kansas is regulated by the Kansas Department of Health and Environment (1986) and the U.S. Environmental Protection Agency (1986a,b). These agencies have set standards for publicwater supplies that can be used also to evaluate "private" drinking-water supplies, which frequently come from shallow domestic wells. These water-quality standards are divided into primary and secondary standards. Primary standards apply to those constituents that have health implications. Secondary standards apply to constituents that affect the aesthetic properties and desirability of water for drinking and domestic uses but are not believed to have health effects. However, some constituents or contaminants of ground water are not included in either primary or secondary standards because adequate knowledge is not available on the effect on humans for all substances that could contaminate ground water. For these reasons, desirable concentrations in drinking water have been suggested by various health organizations or have been derived from available toxicological data. The data are presented in tables 13 to 15 .

\section{Inorganic Constituents}

Inorganic constituents are defined in the following paragraphs, and a summary of standards for these constituents is given in table 13.

Total hardness--Calcium and magnesium are the principal minerals contributing to total hardness. Water with less than $50 \mathrm{mg} / \mathrm{L}$ (milligrams per liter) total hardness (as $\left.\mathrm{CaCO}_{3}\right)$ is considered soft water. Hard water requires more soap or detergent for laundering and has a tendency to develop scale deposits, especially when heated above $140{ }^{\circ} \mathrm{F}$. A total hardness greater than $400 \mathrm{mg} / \mathrm{L}$ is considered excessive (U.S. Environmental Protection Agency, 1986b). 
Table 13. Summary of drinking-water standards and recommended limits for inorganic constituents

Constituent

Unit of

Drinking-water standard

measurement $\quad$ Primary ${ }^{1} \quad$ Secondary 2

Suggested 1 imit3

\begin{tabular}{|c|c|c|c|c|}
\hline Total hardness ( $\mathrm{CaCO} 3)$ & milligrams per liter & -- & 400 & -- \\
\hline Calcium ( $\mathrm{Ca}$ ) & do. & -- & -- & $75-200$ \\
\hline Magnesium ( $\mathrm{Mg})$ & do. & -- & -- & $50-150$ \\
\hline Sodium $(\mathrm{Na})$ & do. & -- & -- & 100 \\
\hline Potassium $(\mathrm{K})$ & do. & -- & -- & 100 \\
\hline Total alkalinity ( $\mathrm{CaCO} 3)$ & do. & -- & -- & $60-300$ \\
\hline Chloride (Cl) & do. & -- & 250 & -- \\
\hline Sulfate $\left(\mathrm{SO}_{4}\right)$ & do. & -- & 250 & - \\
\hline Nitrate (as $\mathrm{N})$ & do. & 10 & -- & -- \\
\hline Fluoride (F) & do. & 4.0 & 2.0 & -- \\
\hline $\mathrm{pH}$ & standard units & -- & $6.5-8.5$ & -- \\
\hline Turbidity & $\begin{array}{l}\text { nephelometric } \\
\text { turbidity units, } \\
\text { NTU }\end{array}$ & 14 & - & -- \\
\hline Specific conductance & $\begin{array}{l}\text { microsiemens per } \\
\text { centimeter at } 25 \\
\text { degrees Celsius }\end{array}$ & -- & -- & 1,500 \\
\hline Dissolved solids & milligrams per liter & -- & 500 & -- \\
\hline Total phosphorus & do. & -- & -- & 5.0 \\
\hline Silica $\left(\mathrm{SiO}_{2}\right)$ & do. & -- & -- & 50 \\
\hline Ammonia (as N) & do. & -- & -- & 0.1 \\
\hline Iron $(\mathrm{Fe})$ & do. & -- & .3 & - \\
\hline Manganese (Mn) & do. & -- & .05 & - \\
\hline
\end{tabular}

1 U.S. Environmental Protection Agency, 1986a.

2 U.S. Environmental Protection Agency, 1986b.

3 Kansas Department of Health and Environment, 1986.

4 Treated surface water.

Sodium--Sodium is an essential nutrient. The dietary requirement for sodium is less than 1,000 milligrams per day for adults. However, adults in the United States typically have a total sodium intake of 3,000 to 4,000 milligrams per day. There is a great deal of evidence that excessive sodium intake contributes to an agerelated increase in blood pressure in genetically susceptible people. Therefore, the suggested limit for sodium in drinking water has been set at $100 \mathrm{mg} / \mathrm{L}$ (Kansas Department of Health and Environment, 1986). Persons on a sodiumrestricted diet may require water with a sodium concentration less than this guideline, but persons not susceptible to high blood pressure can tolerate sodium well in excess of the suggested limit. Ion-exchange water softeners add quantities of sodium to softened water.

Potassium--The concentration of potassium normally detected in drinking water has no health or aesthetic effects on drinking-water users.

Alkalinity--The alkalinity of water is a measure of its capacity to neutralize acids. Bicarbonate and carbonate are the major contributors to alkalinity, but borates, silicates, hydroxide, and phosphates also contribute. The relationship of $\mathrm{pH}$, calcium, and alkalinity determine whether a water is corrosive or whether it will deposit calcium carbonate. 
The Kansas Department of Health and Environment (1986) suggests the alkalinity of treated water be at least $60 \mathrm{mg} / \mathrm{L}$ to prevent corrosiveness.

Chloride--The secondary drinking-water standard for chloride is $250 \mathrm{mg} / \mathrm{L}$ because some people can detect a salty taste at that concentration. Chloride has no serious health effect at this concentration. Corrosion of metal is accelerated as chloride concentration increases.

Sulfate--The secondary drinking-water standard for sulfate is $250 \mathrm{mg} / \mathrm{L}$ because of the bitter taste and laxative effects of excessive sulfate. Sulfate also accelerates corrosion of metal.

Nitrate--The primary drinking-water standard for nitrate, reported as nitrogen, is 10 $\mathrm{mg} / \mathrm{L}$. Excessive nitrate consumption by infants; less than 1 year in age may result in infant cyanosis, also called methemoglobinemia or "blue baby syndrome." A nitrate concentration of $10 \mathrm{mg} / \mathrm{L}$ is considered safe for infants however, adults can tolerate much larger concentrations without ill effects. Since 1940, 20 cases of methemoglobinemia reported in Kansas have been associated with water supplies containing 30 to $180 \mathrm{mg} / \mathrm{L}$ nitrate as nitrogen. Young animals may be at greater risk than humans, as their dietary intake of nitrate is generally greater. Ruminants (cattle, sheep, and so forth) are most sensitive to nitrate.

Fluoride--The primary drinking-water standard for fluoride is $4.0 \mathrm{mg} / \mathrm{L}$; the secondary standard is $2.0 \mathrm{mg} / \mathrm{L}$. A fluoride concentration of approximately $1.0 \mathrm{mg} / \mathrm{L}$ helps prevent dental cavities. At concentrations less than $0.7 \mathrm{mg} / \mathrm{L}$, fluoride will not be of any benefit. At concentrations greater than $2.0 \mathrm{mg} / \mathrm{L}$, fluoride may cause mottling of the teeth. Bone changes can occur if drinking water contains 8 to $20 \mathrm{mg} / \mathrm{L}$ of fluoride, and if fluoride exceeds $20 \mathrm{mg} / \mathrm{L}$, crippling fluorosis can occur after long-term consumption.

$p H$--Standard units of $\mathrm{pH}$, which is the negative log of the hydrogen-ion concentration, extend from zero (very acidic) to 14 (very alkaline), with 7 being neutral. The desirable $\mathrm{pH}$ range for drinking water is from 6.5 to 8.5.
A pH of less than 6.0 or more than 10.0 could indicate the presence of a contamination source.

Turbidity--Turbidity in water is the suspended material that causes a beam of light to scatter. Turbidity can be aesthetically and physiologically significant because it can provide a medium for bacterial growth. The drinking-water standard for treated surface water is a maximum 2-day average of 5 nephlometric turbidity units (NTU) and a maximum average of 1 NTU over a 30-day period. No standards have been established for ground water.

Specific conductance--Conductance is a numerical expression of the ability of water to conduct an electric current. Because the number, which is expressed as microsiemens per centimeter at $25^{\circ} \mathrm{C}$ (microsiemens), depends on the concentration of the dissolved minerals, conductance indicates the degree of mineralization in the water. Specific conductance greater than 1,500 microsiemens is considered excessive.

Dissolved solids--Dissolved solids is a measure of the dissolved material in water. Concentrations of dissolved solids greater than $500 \mathrm{mg} / \mathrm{L}$ are objectionable because of a mineral taste and possible health effects. Water containing more than $1,000 \mathrm{mg} / \mathrm{L}$ dissolved solids can be expected to accelerate corrosion.

Total phosphorus--Phosphate is a nutrient that in concentrations normally detected in water has no physiological significance. The recommended State limit is based on the fact that concentrations greater than $5.0 \mathrm{mg} / \mathrm{L}$ may indicate contamination from human or animal wastes.

Ammonia--Ammonia is the biologically reduced form of nitrogen and can occur naturally in surface and ground water. At concentrations normally found, it has no health effects. It may cause unpleasant odors at concentrations greater than $0.03 \mathrm{mg} / \mathrm{L}$. Concentrations greater than $0.1 \mathrm{mg} / \mathrm{L}$ may indicate contamination from surface pollutants, such as septic-tank leaching fields.

Silica--Silica is the oxidized form of the element silicon and occurs in small 
concentrations in most natural waters. Silica has no physiological significance to humans but can cause crusting deposits on well screens or pumps, piping, or water heaters. Concentrations greater than $50 \mathrm{mg} / \mathrm{L}$ may cause an undesirable cloudy appearance.

Iron--Iron is objectionable because of taste, red staining of porcelain fixtures and laundry, and deposition in plumbing. The secondary drinking-water standard for iron is $0.3 \mathrm{mg} / \mathrm{L}$.

Manganese--The secondary drinking-water standard for manganese is $0.05 \mathrm{mg} / \mathrm{L}$. Manganese in concentrations greater than 0.05 $\mathrm{mg} / \mathrm{L}$ is objectionable because of unpleasant taste, black staining of porcelain fixtures and laundry, and deposition in plumbing. Manganese produces no significant health effects

\section{Trace Elements}

Trace elements are also inorganic constituents of ground water, but they have added significance in that most are toxic to humans and animals in large concentrations. Trace elements are present in the soil and geologic formations of Kansas, but due to their small solubility in water, only trace concentrations normally are found. The solubility of trace elements in synthetic-organic compounds can be greater than in water and are, therefore, of concern when agricultural chemicals are applied. Table 14 lists the primary and secondary drinking-water standards for trace elements.

\section{Pesticides}

Drinking-water standards have been established for only a few pesticides even though toxicity information is available for most formulations. The long-term human-health effects of many pesticides are unknown. Health advisory levels in drinking water and any known long-term effects are given in table 15. Chronic health effects may occur after longterm consumption of water containing a pesticide at 10 to 100 times the health advisory level.

\section{PRELIMINARY GROUND-WATER- QUALITY ASSESSMENT}

Many ground-water samples from wells throughout the State were examined for agricultural chemical contamination. Data included an extensive study of selected chemical constituents in water from 766 wells representing all Kansas counties from 1976-81 (Spruill, 1983). A random farmstead well survey (Koelliker and others, 1987) examined 103 wells in several counties for selected chemical constituents during 1985-86. Also included in the preliminary ground-waterquality assessment were selected pesticide analyses of ground-water samples collected from wells determined to be located in areas that may be susceptible to rapid rates of leaching. These additional samples were collected from 56 wells during 1985-86.

\section{Kansas Ground-Water-Quality Monitoring Network, 1976-81}

Information from the 766 wells sampled from 1976-81 (Spruill, 1983) revealed widespread contamination of ground water by nitrate-nitrogen. Fourteen percent of the samples had nitrate-nitrogen concentrations exceeding the drinking-water standard or maximum contaminant level (MCL) of $10 \mathrm{mg} / \mathrm{L}$ (U.S. Environmental Protection Agency, 1986a). In Spruill's report (1983), the State was divided into 14 regions on the basis of geohydrologic factors to show regional variance. The geohydrologic regions and the percentage of sampled wells in which nitrate-nitrogen concentrations exceeded the MCL are shown in figure 8. Table 16 lists the statistical distributions within each region.

As a result of years of nitrogen application to the soil, nitrate contamination has occurred in ground water in each of the 14 geohydrologic regions in the State (fig. 8). The $10-\mathrm{mg} / \mathrm{L}$ drinking-water standard $r, r$ nitrate-nitrogen was exceeded occasionally in 13 of the 14 regions. Median nitrate-nitrogen concentrations exceeded $3 \mathrm{mg} / \mathrm{L}$ in seven of the regions; concentrations greater than $50 \mathrm{mg} / \mathrm{L}$ occurred in four of the regions. Regions 2, 5, and 9 had the largest percentages of wells with ground water containing nitrate-nitrogen concentrations exceeding the MCL $(30,22$, and 20 percent, respectively). Ground water exceeding the MCL occurred in 9 to 20 percent of 
Table 14. Summary of drinking-water standards and chronic health effects for trace elements

\begin{tabular}{|c|c|c|c|}
\hline $\begin{array}{l}\text { Trace } \\
\text { element }\end{array}$ & $\begin{array}{l}\text { Drinking-wat } \\
\text { Primary } 1 \\
\text { (milligrams } \\
\text { per liter) }\end{array}$ & $\begin{array}{l}\text { er standard } \\
\text { Secondary } \\
\text { (milligrams } \\
\text { per liter) }\end{array}$ & Chronic health effects 3 \\
\hline Arsenic (As) & 0.05 & -- & $\begin{array}{l}\text { Suspected carcinogen; blackfoot } \\
\text { disease; pigmentation changes; } \\
\text { fatigue, energy loss; } \\
\text { accumulates in skin, bone, and } \\
\text { muscle. }\end{array}$ \\
\hline Barium ( $\mathrm{Ba}$ ) & 1.0 & -- & $\begin{array}{l}\text { Accumulates in liver, lungs, and } \\
\text { spleen. }\end{array}$ \\
\hline Cadmium (Cd) & .01 & -- & $\begin{array}{l}\text { Bronchitis, emphysema, anemia; } \\
\text { accumulates in liver and } \\
\text { kidneys. }\end{array}$ \\
\hline Chromium $(\mathrm{Cr})$ & .05 & -- & $\begin{array}{l}\text { Dermatitis; skin and nasal } \\
\text { ulcers; accumulates in spleen, } \\
\text { bones, kidney, and liver. }\end{array}$ \\
\hline Copper (Cu) & -- & 1.0 & $\begin{array}{l}\text { Copper in drinking water has no } \\
\text { health significance because } \\
\text { the concentrations required to } \\
\text { produce health effects exceed } \\
\text { the maximum possible } \\
\text { concentrations. }\end{array}$ \\
\hline Lead $(\mathrm{Pb})$ & .05 & -- & $\begin{array}{l}\text { Nervous system, kidney, and } \\
\text { blood disorders. }\end{array}$ \\
\hline Mercury (Hg) & .002 & -- & $\begin{array}{l}\text { Headaches; giddiness; kidney } \\
\text { damage (ulceration). }\end{array}$ \\
\hline Selenium ( $\mathrm{Se}$ ) & .01 & -- & $\begin{array}{l}\text { Depression, nervousness, giddi- } \\
\text { ness, dermatitis, gastrointes- } \\
\text { tinal disturbance, dental } \\
\text { decay, garlic-breath odor; } \\
\text { accumulates in hair and nails. }\end{array}$ \\
\hline Silver $(\mathrm{Ag})$ & .05 & -- & $\begin{array}{l}\text { Blue-gray discoloration of the } \\
\text { skin, mucous membranes, and } \\
\text { eyes; cosmetic effects only. }\end{array}$ \\
\hline
\end{tabular}


Table 14. Summary of drinking-water standards and chronic health effects for trace elements-Continued

\begin{tabular}{lcc}
\hline $\begin{array}{l}\text { Trace } \\
\text { element }\end{array}$ & $\begin{array}{c}\text { Drinking-water standard } \\
\text { Primary } \\
\text { (miligrams } \\
\text { per liter) }\end{array}$ & $\begin{array}{c}\text { Secondary } \\
\text { (milligrams } \\
\text { per liter) }\end{array}$ \\
\hline Zinc $(2 n)$ & 5.0 & $\begin{array}{c}\text { Irritability, muscular } \\
\text { stiffness, loss of appetite, } \\
\text { nausea; essential trace } \\
\text { element; protects against lead } \\
\text { and cadmium toxicity. }\end{array}$ \\
\hline
\end{tabular}

1 U.S. Environmental Protection Agency, 1986a.

2 U.S. Environmental Protection Agency, 1986b.

3 Kansas Department of Health and Environment, 1986. Chronic health effects may appear in sensitive individuals after long-term consumption at concentrations 10 to 100 times the established standards.

the wells in regions $1,4,6,7,8,11$, and 13 . The median nitrate concentration $(5.6 \mathrm{mg} / \mathrm{L})$ was largest in region 8 . This region also had the most favorable hydrologic agricultural factors for the leaching of chemicals to ground water (permeable soil, sandy unconsolidated lithology, shallow water table, and intensive agricultural activity). However, every region except region 3 had wells in which sample concentrations exceeded the MCL for nitratenitrogen.

Ground-water samples from the 766 wells were analyzed for the six pesticides for which a MCL exists. These chemicals were endrin, lindane, methoxychlor, and toxaphene, which are insoluble insecticides, and 2,4-D and silvex, which are herbicides and, as acids, are also insoluble. The insolubility of the six pesticides in water is the primary reason that only one compound, silvex, was detected in only one well of the 766 tested. That one sample indicated a concentration of $0.2 \mu \mathrm{g} / \mathrm{L}$ (microgram per liter), which is the detection limit for silvex. There were no analyses for the more soluble pesticides.
A random scheme to draw a sample of 103 wells from a population of over 40,000 farmstead wells was designed and carried out during 1985 and 1986 (Koelliker and others, 1987). Samples were analyzed for 20 pesticides, 29 volatile organic compounds (VOC), and 21 inorganic compounds, including nitratenitrogen. Of the wells sampled, 9 percent had detectable pesticides, 2 percent had detectable VOC, and 37 percent had inorganic chemicals exceeding the MCL.

Nitrate-nitrogen concentrations greater than $10 \mathrm{mg} / \mathrm{L}$ were found in 28 percent of the wells sampled. Farmstead wells in the northeast, north-central, and south-central reporting districts of the State (fig. 3) had a higher probability of nitrate-nitrogen contamination, with mean concentrations of $14.98,11.61$, and $9.06 \mathrm{mg} / \mathrm{L}$, respectively. Atrazine was found in four wells; 2,4-D and $2,4,5-T$ were found together in one well; alachlor and 1,2-dichloroethane in one well; and tordon and benzene in one well each. Regional analysis of pesticide distribution was not possible.

\section{Kansas Farmstead-Well Survey, $1985-86$}




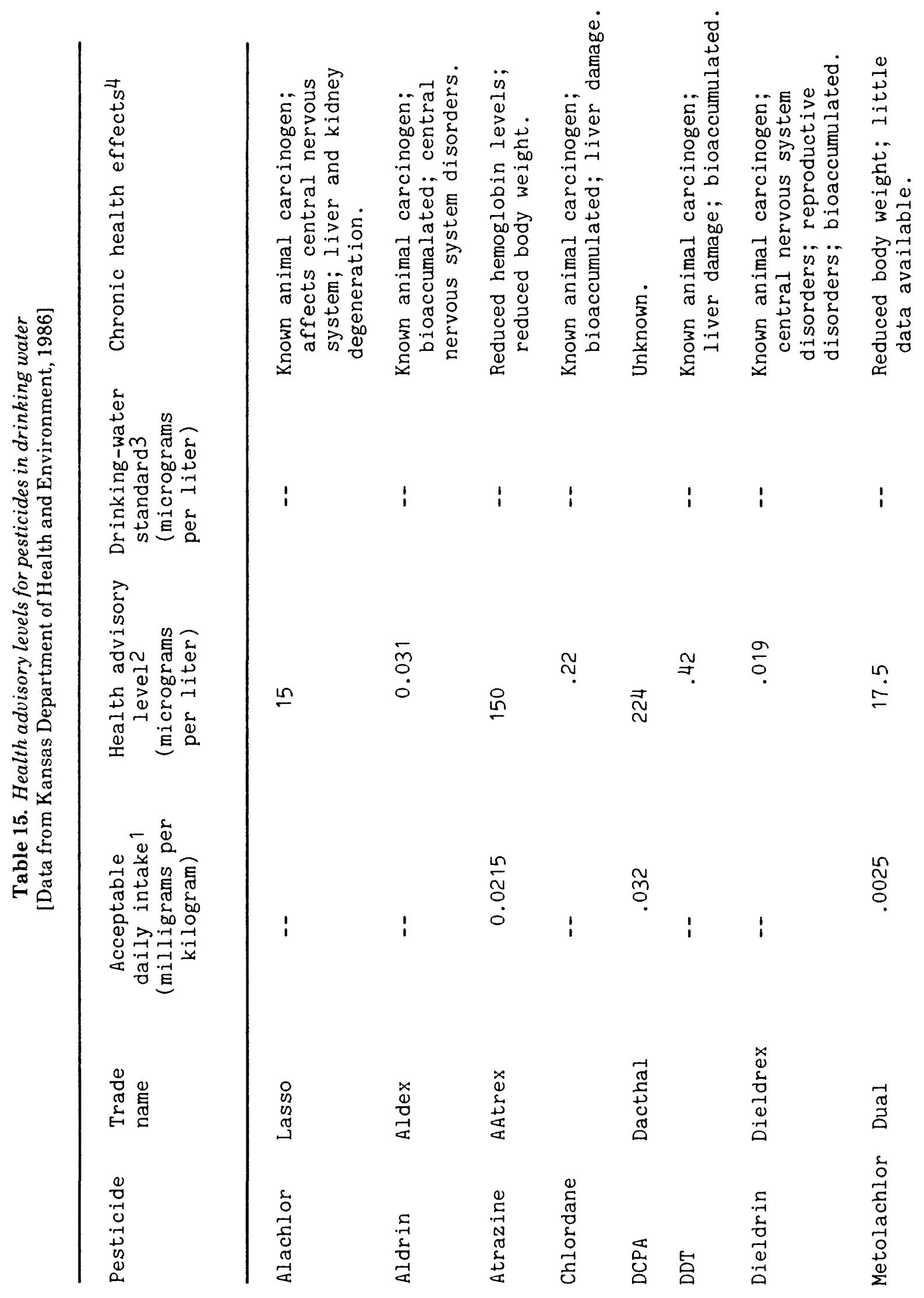




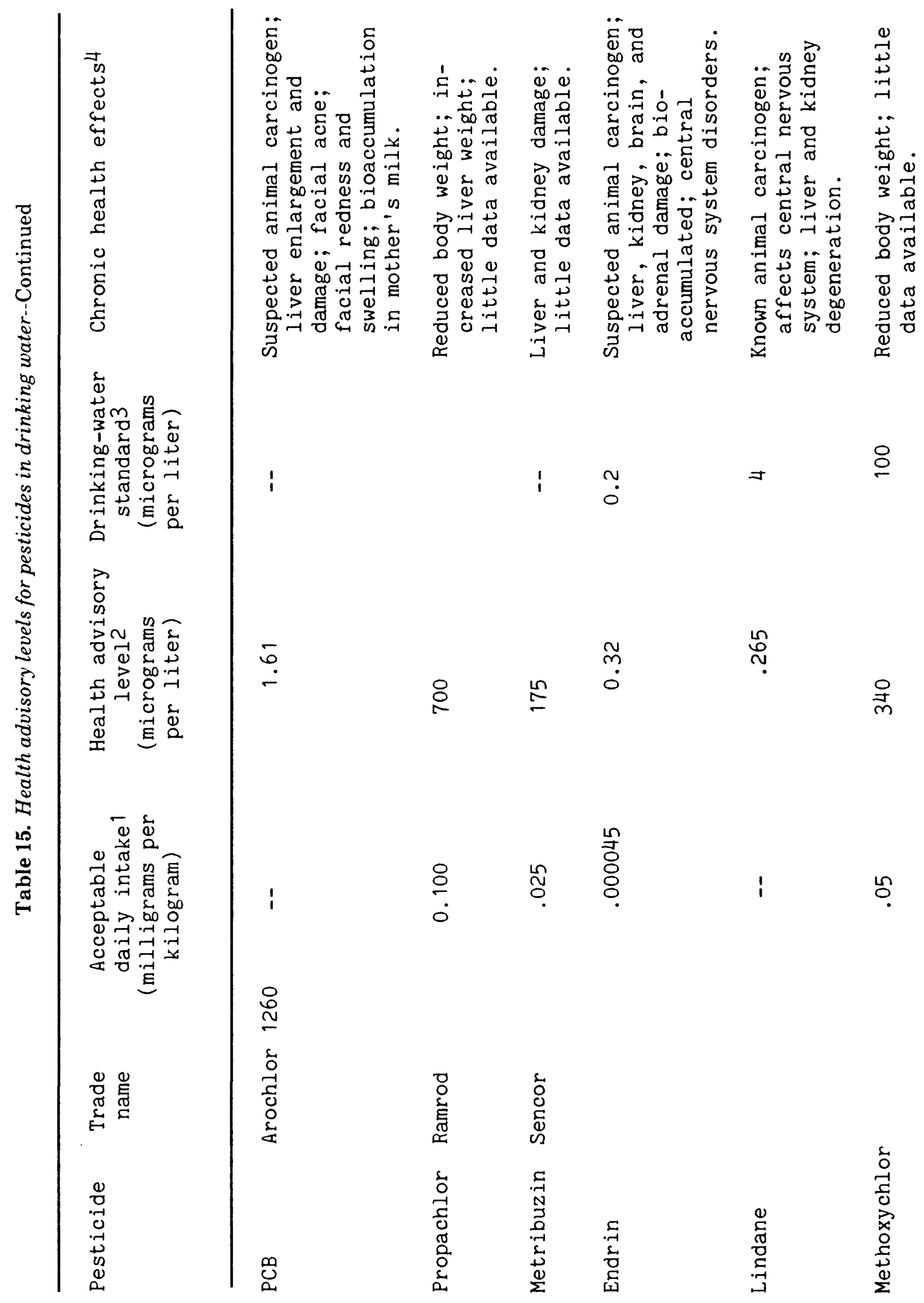




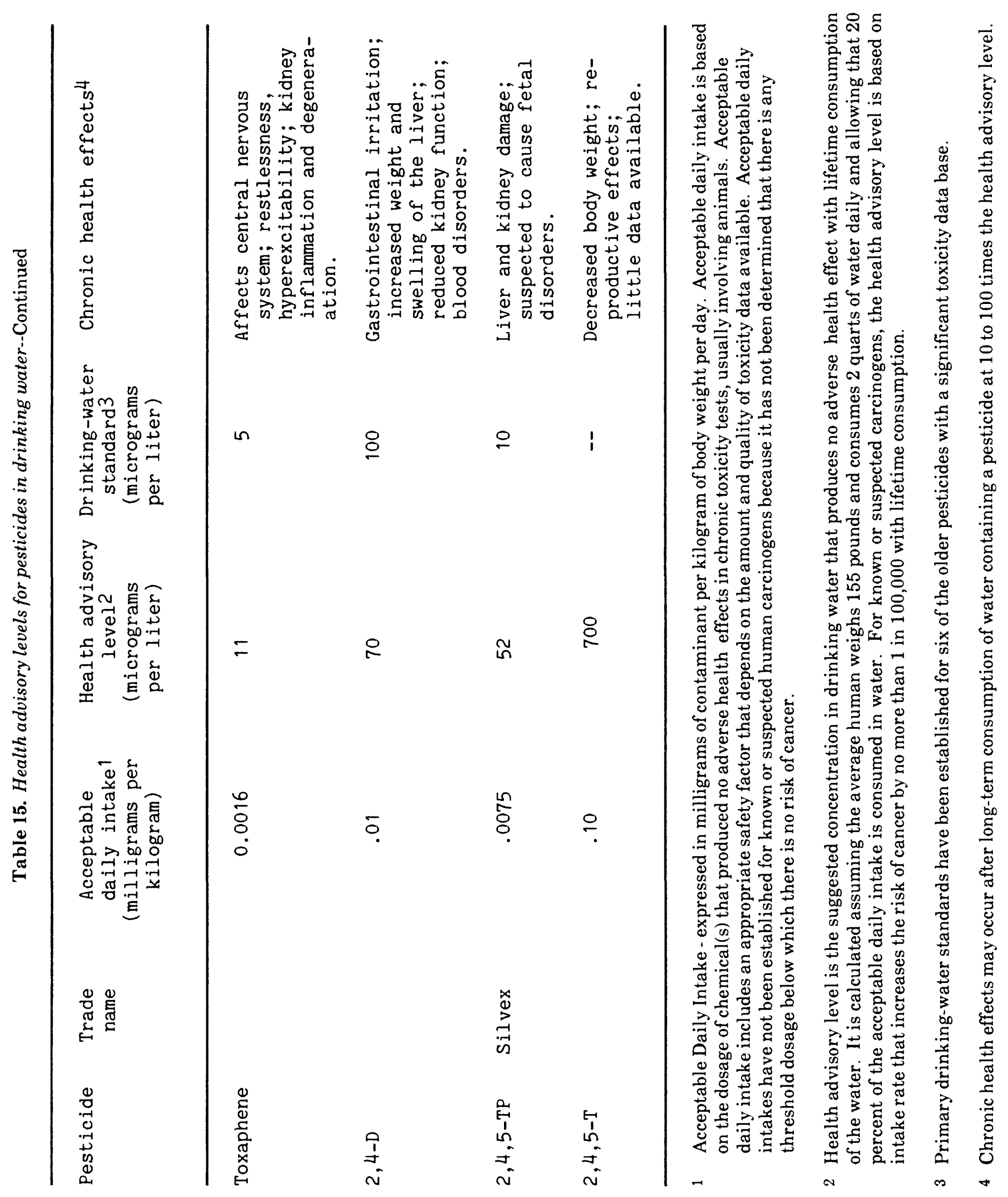




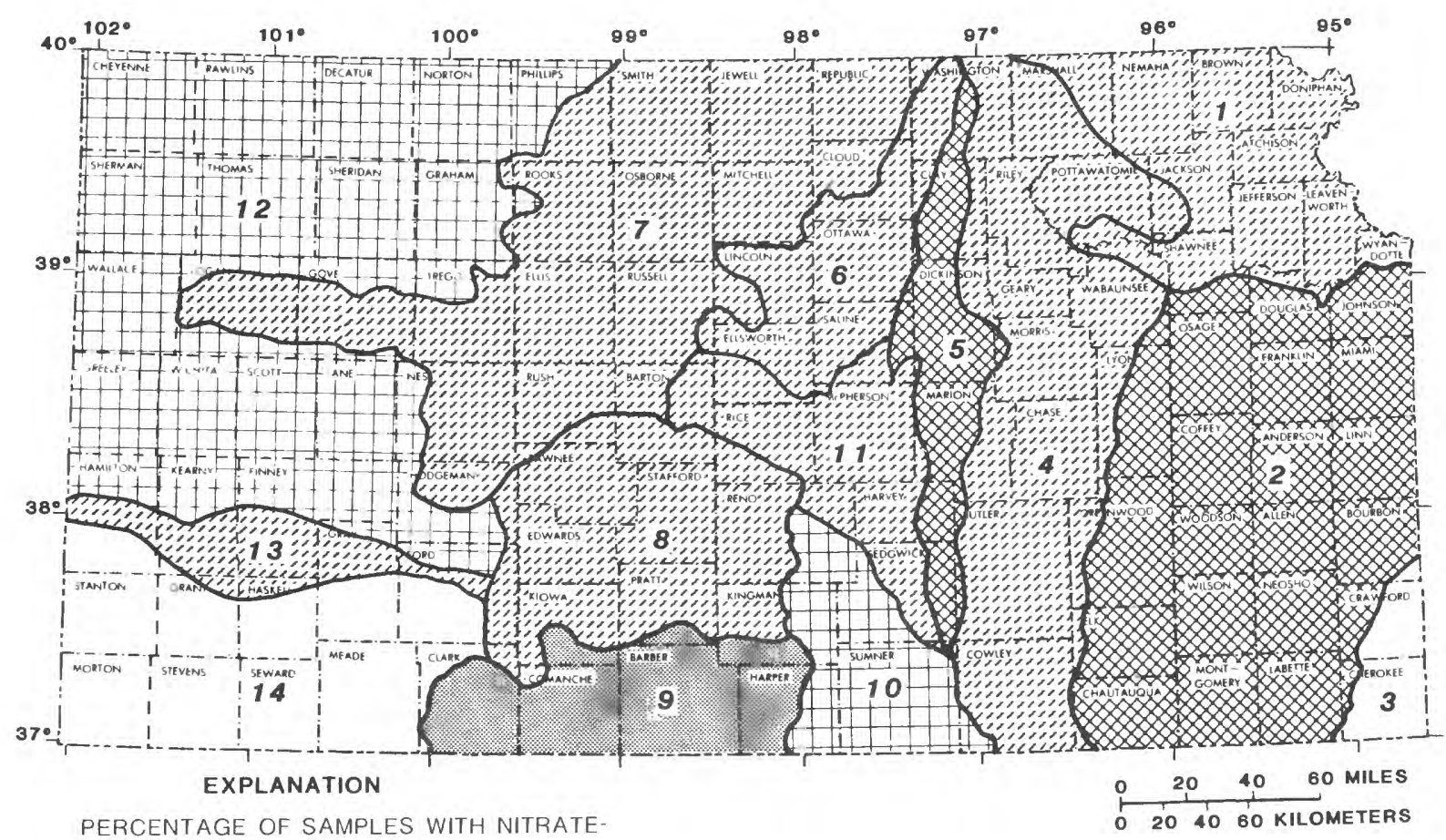

NITROGEN CONCENTRATIONS GREATER

THAN 10 MILLIGRAMS PER LITER
$\square$ Less than 3
$16-20$
ए $3-8$
Grealer than 20
9-15
9 GROUND-WATER REGION AND NUMBER

Figure 8. Ground-water regions and percentage of ground-water samples with dissolved nitrate-nitrogen concentrations exceeding drinking-water standard of 10 milligrams per liter.

Table 16. Dissolved nitrate-nitrogen concentrations in Kansas ground-water supplies, 1976-81 [Data from Spruill, 1983|

\begin{tabular}{|c|c|c|c|c|c|c|}
\hline \multirow{2}{*}{$\begin{array}{l}\text { Ground- } \\
\text { water } \\
\text { region } \\
\text { (fig. } 8 \text { ) }\end{array}$} & \multirow[b]{2}{*}{$\begin{array}{l}\text { Number } \\
\text { of } \\
\text { samples }\end{array}$} & \multicolumn{4}{|c|}{$\begin{array}{c}\text { Quartile values of nitrate-nitrogen } \\
\text { concentrations } \\
\text { (milligrams per liter) }\end{array}$} & \multirow{2}{*}{$\begin{array}{c}\text { Percentage } \\
\text { greater } \\
\text { than } \\
\text { drinking- } \\
\text { water } \\
\text { standard } 1\end{array}$} \\
\hline & & $1 \mathrm{st}$ & $\begin{array}{c}\text { 2nd } \\
\text { (median) }\end{array}$ & $3 r d$ & $\begin{array}{c}4 \text { th } \\
\text { (maximum) }\end{array}$ & \\
\hline 1 & 71 & 0.1 & 1.5 & 7.0 & 89 & 13 \\
\hline 2 & 82 & .7 & 4.0 & 13 & 120 & 30 \\
\hline 3 & 10 & 0 & 0 & 0 & .6 & 0 \\
\hline 4 & 60 & 1.2 & 3.9 & 7.8 & 15 & 11 \\
\hline 5 & 18 & .2 & 2.7 & 10 & 28 & 22 \\
\hline 6 & 62 & .3 & 2.8 & 6.1 & 87 & 14 \\
\hline 7 & 112 & .4 & 2.8 & 6.6 & 56 & 14 \\
\hline 8 & 62 & 3.7 & 5.6 & 8.7 & 29 & 11 \\
\hline 9 & 25 & .6 & 2.7 & 8.0 & 41 & 20 \\
\hline 10 & 24 & .9 & 3.2 & 7.4 & 13 & 8 \\
\hline 11 & 53 & .6 & 3.4 & 5.8 & 26 & 10 \\
\hline 12 & 95 & 3.1 & 4.5 & 6.0 & 32. & 6 \\
\hline 13 & 28 & .3 & 2.7 & 6.7 & 21 & 11 \\
\hline 14 & 48 & .1 & 3.2 & 3.9 & 13 & 2 \\
\hline
\end{tabular}

1 U.S. Environmental Protection Agency (1986a) 


\section{Additional Sampling, 1985-86}

The presence of nitrate-nitrogen contamination in Kansas ground water has been proven by the fact that nearly 16 percent (137 of 869) of the wells tested by the groundwater-quality monitoring network and the Kansas farmstead well survey had nitratenitrogen concentrations exceeding the MCL. However, only 1 percent (10 of 869 ) had detectable levels of pesticides. One explanation of the small number of positive pesticide detections was that the samples were tested for a limited number and type of pesticides. The ground-water testing from 1976-81 (Spruill, 1983) included only four insecticides and two herbicides, all of which were insoluble in water. Only 5 of the 20 pesticides examined by Koelliker and others (1987) were soluble in water. The economics of sample analysis helped dictate the compounds that were chosen. An additional sampling scheme was needed to economize analysis costs while maintaining the number of samples.

The additional sampling scheme consisted of sampling ground water from wells located in areas susceptible to leaching and having that sample analyzed for only the pesticides that were used nearby. This technique was used to sample 56 wells during $1985-86$ in areas that had permeable soil (class 1 or 2) and shallow water tables (less than 30 feet below land surface). These areas were the Kansas River basin alluvium and parts of south-central Kansas. The samples were analyzed for the triazine group of herbicides (atrazine, cyanazine, simazine, propazine, and trifluralin), alachlor, metolachlor, and metribuzin.

Of the 56 wells sampled, 11 wells (20 percent) had pesticide concentrations exceeding detection limits. The wells with positive detections are listed in table 17. Eleven samples of ground water from nine wells contained atrazine, with concentrations ranging from less than 0.1 to $46 \mu \mathrm{g} / \mathrm{L}$. Four samples from three wells contained cyanazine in concentrations ranging from 0.7 to $3.7 \mu \mathrm{g} / \mathrm{L}$. Propazine $(0.2$ $\mu \mathrm{g} / \mathrm{L})$ and simazine $(0.1 \mu \mathrm{g} / \mathrm{L})$ were detected in only one sample (Sedgwick County, southcentral Kansas). Three other herbicides were also detected: alachlor $(1.9 \mathrm{\mu g} / \mathrm{L})$; metolachlor $(6.0 \mu \mathrm{g} / \mathrm{L}$ in water from one well, 43 and $55 \mu \mathrm{g} / \mathrm{L}$ in two water samples from another well); and metribuzin $(14 \mu \mathrm{g} / \mathrm{L})$ in one sample.

Because the largest concentrations of atrazine $(46 \mu \mathrm{g} / \mathrm{L})$, cyanazine $(3.7 \mu \mathrm{g} / \mathrm{L})$, metolachlor $(55 \mu \mathrm{g} / \mathrm{L})$, and the only detectable concentrations of metribuzin $(14 \mu \mathrm{g} / \mathrm{L})$ and alachlor $(1.9 \mu \mathrm{g} / \mathrm{L})$ were from water at only one site--the Hesston agronomy farm, approximately in the center of the State--it is uncertain how serious the problem of large concentrations of these herbicides is throughout the State.

Table 17. Pesticides detected in Kansas ground water, 1985-86

Location of well Date Pesticide $\begin{gathered}\text { Concentration } \\ \text { (latitude- }\end{gathered}$
longitude)

Hesston agronomy farm

$\begin{array}{llc}\text { (38007'59"-97026'24") } 11 / 05 / 85 & \text { Atrazine } & 34 \\ & \begin{array}{l}\text { Metolachlor } \\ \text { Cyanazine }\end{array} & 55 \\ & \text { Atrazine } & 3.0 \\ & \text { Metolachlor } & 46 \\ & \text { Metribuzin } & 43 \\ & \text { Cyanazine } & 14 \\ & \text { Alachlor } & 3.7 \\ & & 1.9\end{array}$


Table 17. Pesticides detected in Kansas ground water, 1985-86--Continued

\begin{tabular}{l}
$\begin{array}{l}\text { Location of well Date } \\
\text { (latitude- } \\
\text { longitude) }\end{array}$ \\
\hline
\end{tabular}

\section{Topeka agronomy farm}

$\begin{array}{rrrr}\left(39005^{\prime} 00^{\prime \prime}-95046^{\prime} 07^{\prime \prime}\right) & 10 / 03 / 85 & \text { Atrazine } & 0.7 \\ & 05 / 23 / 86 & \text { Atrazine } & \text { Trace }\end{array}$

\section{Wakarusa River}

valley

$$
\begin{array}{lll}
\text { (38056'05"-95008'56") } 11 / 01 / 85 & \text { Atrazine } & 1.9 \\
\text { Republican River } & & \\
\quad \text { valley, } & & \\
\text { Junction City } & & \\
\text { (39005'57"-96049'06") } 11 / 27 / 85 & \text { Cyanazine } & 1.1
\end{array}
$$

Kansas River

valley, Manhattan

$$
\text { (39008'17"-96034'14") 12/18/85 Atrazine .3 }
$$

\section{Smoky Hill River, \\ Enterprise}

$$
\text { (38054'44"-97007'02") 11/26/85 Cyanazine }
$$

\section{Sedgwick County}

\begin{tabular}{llll}
$\left(38029^{\prime} 32^{\prime \prime}-97021^{\prime} 46^{\prime \prime}\right)$ & $08 / 15 / 85$ & Atrazine & .1 \\
$\left(38043^{\prime} 56^{\prime \prime}-97024^{\prime} 29^{\prime \prime}\right)$ & $08 / 12 / 85$ & $\begin{array}{l}\text { Atrazine } \\
\text { Propazine }\end{array}$ & .2 \\
& $\begin{array}{l}\text { Simazine } \\
.1\end{array}$ \\
$\left(38051^{\prime} 11^{\prime \prime}-97028^{\prime} 11^{\prime \prime}\right)$ & $08 / 13 / 85$ & Atrazine & .2 \\
$\left(38052^{\prime} 10^{\prime \prime}-97031^{\prime} 03^{\prime \prime}\right)$ & $08 / 12 / 85$ & Atrazine & .4 \\
$\left(38053^{\prime} 48 "-97028 \cdot 19^{\prime \prime}\right)$ & $08 / 14 / 85$ & $\begin{array}{l}\text { Atrazine } \\
\text { Metolachlor }\end{array}$ & .3 \\
\hline
\end{tabular}




\section{NEED FOR FUTURE STUDY}

\section{Problem}

Because of the complexities associated with pesticide leaching through the soil, its transformation and degradation, and the multitude of combinations of soil, water, and chemicals, the scope of the potential contamination problem in Kansas has remained poorly defined. There are many different individual soil types in Kansas that range from impermeable clay to very porous sand. Water available for infiltration also varies greatly, with the southeastern part of the State receiving more than 40 inches of rainfall annually to less than 20 inches along the western border. Crops vary from short-grass pastures to row crops. Application rates of the more common pesticides are such that degradation of aquifers in the future may be much more severe than the degradation that already has been detected as indicated by the preliminary assessment of ground-water samples from potential problem areas.

The hypothesis that pesticide residuals and degradation products are being concentrated in the unsaturated zone needs to be tested. The extent of the present contamination of ground water could be much worse than the data indicate. The research effort would include intensive onsite and laboratory studies at an optimum network of experimental sites that are representative of major agricultural areas in Kansas and much of the Nation.

\section{Major Objectives}

The research effort would better define the characteristics of pesticide leaching and persistence from the land surface through the unsaturated zone into the saturated zone. The dynamics of the physical and chemical processes are complex and are difficult to evaluate. However, these processes can be grouped into six major categories that have become the objectives of the future study:

1. Determine field values of decay rates for selected pesticides.

2. Determine the spacial and temporal distribution of pesticide residues and their degradation products in the surface soils, unsaturated zone, and ground water.

3. Determine infiltration and groundwater-recharge rates.

4. Determine the extent of short-term (monthly) and long-term (yearly) pesticide leaching for various soil types, and the effects of precipitation timing and(or) application of irrigation water on leaching rates.

5. Determine the effect of chemigation (addition of fertilizers and pesticides to irrigation waters) on the leaching of pesticides to the ground water.

6. Compare measured results of pesticide decay and leaching with estimates produced by the numerical Pesticide Root Zone Model (Carsel and others, 1984) and the LEACH handbook (Dean and others, 1984) for validation of these tools for use at other locations.

The study would include a sufficient number of experimental sites representing a range of soil types, from sandy loam to clay, and climate, from subhumid to semiarid. Pesticides studied would include the most commonly used herbicides--atrazine, metolachlor, alachlor, 2,4$\mathrm{D}$, and trifluralin.

Determination of pesticide decay rates would be limited by the environmental and soil conditions present at the experimental sites. This limitation also applies in determining the distribution of pesticides from the surface to the water table. Onsite data acquired during at least two growing seasons would be used in the testing of the Pesticide Root Zone Model and the LEACH handbook estimates. An investigation of chemigation, which is the injection of agricultural chemicals into irrigation water, would focus on center-pivot systems and a single herbicide, such as atrazine.

\section{Approach}

The objectives of this study would be accomplished by a detailed study of pesticide leaching and persistence on agricultural lands 
in Kansas. A network of experimental sites currently exists in the form of the Kansas State University agronomy farms and experimental stations (fig. 9). These farms and stations are at locations that represent large agricultural regions of Kansas. Research at these farms and stations is conducted on agricultural practices that are characteristic of each area, such as crop patterns, pesticide application, and irrigation techniques. Detailed soil analyses have been conducted for most fields, and meticulous pesticide records have been maintained for more than two decades at some sites. Pesticides are applied accurately with special sprayers so that initial concentrations can be determined. Each farm or station has a soil scientist with equipment to aid in soil sampling and soilproperty interpretations. Another very important aspect of using the farms and stations is that most have complete weather stations permanently installed, and data are available for evapotranspiration calculations. Also, the sites have the capability for soil-moisture monitoring.

Sites would be selected in fields at agronomy farms planted to corn, grain sorghum, soybeans, or wheat that had received applications of the herbicides atrazine, metolachlor, alachlor, 2,4$\mathrm{D}$, or trifluralin. In the fields selected for study, soil profiles would be sampled at various depths and at various times during the year. These soil samples would be analyzed for pesticide concentration, soil $\mathrm{pH}$, organic carbon content, particle-size distribution, and moisture content. Water in the unsaturated zone would be sampled by suction lysimeters and analyzed for pesticide and chloride concentrations, $\mathrm{pH}$, and specific conductance.

The infiltration of precipitation or irrigation water would be estimated from infiltrometer and evaporation data. Recharge to the groundwater system would be estimated from data collected by tensiometers, soil-moisture blocks, neutron-moisture meters, and observation wells. From measurements of the amount of water infiltrating the soil surface and the amount reaching the water table as recharge, and with the aid of conservative tracers, the adsorption/desorption phenomena of pesticides in the unsaturated part of the soil profile would be determined.

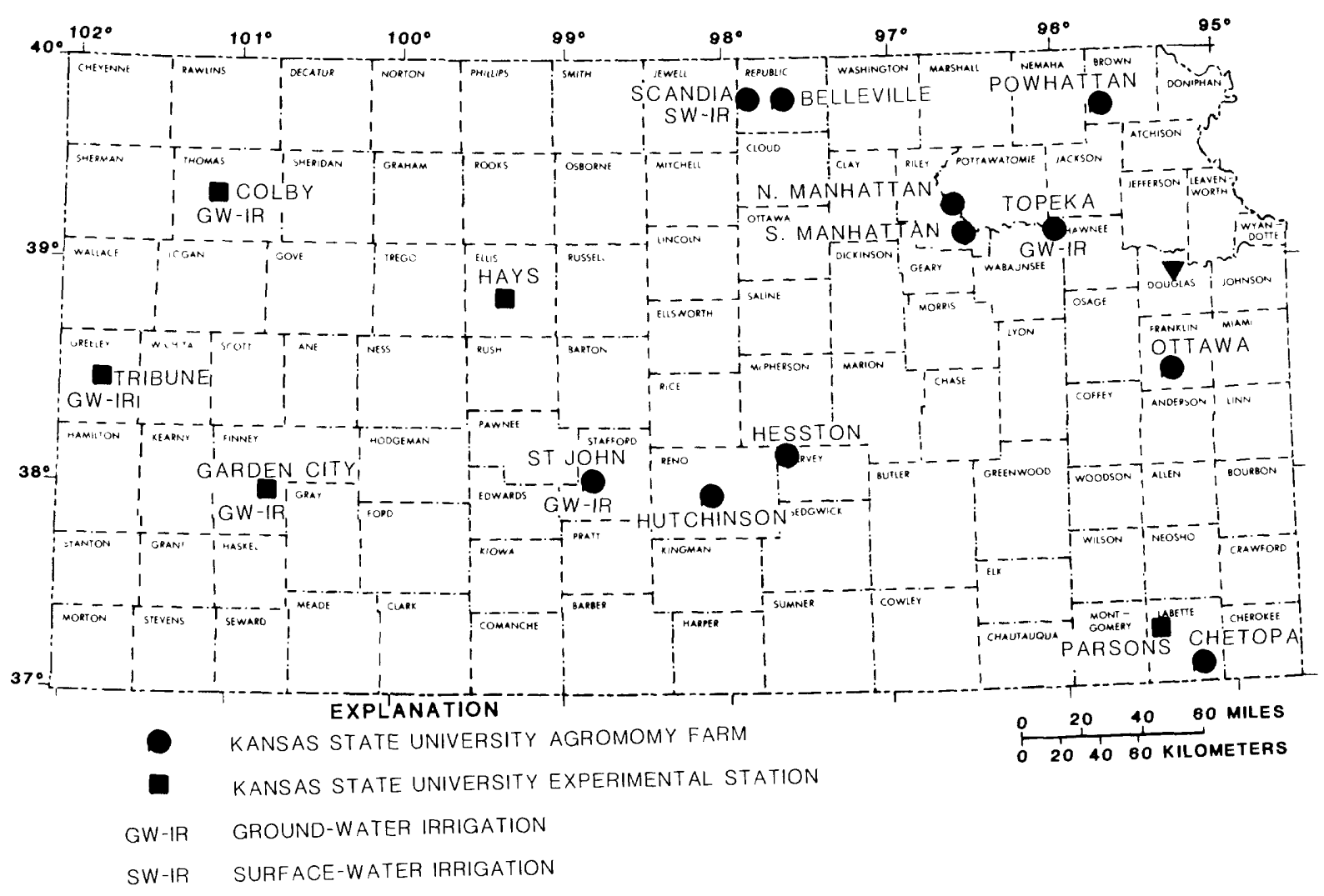

Figure 9. Location of Kansas State University agronomy farms and experimental stations. 
Ground-water samples would be collected and analyzed for several inorganic constituents, including major ions, nitrate, ammonia, and organic constituents (including several classes of pesticides). Onsite water-quality measurements would include $\mathrm{pH}$, water temperature, and specific conductance. Soil samples would be analyzed for particle-size distribution and hydraulic properties. The data would be used to relate constituent concentrations to particle-size distribution. The half-life of selected pesticides would be estimated from residual pesticideconcentration data from the soil, soil-water, and ground-water samples.

Soil and ground water in fields where chemigation is practiced would be sampled before the irrigation season and then immediately after cessation of irrigation in the late summer. Amounts of chemicals applied, approximate amounts of applied water, precipitation data collected at nearby rain gages, and type of irrigation equipment would be noted.

Results of the analyses of the pesticide residues in soil samples and water samples obtained at the test sites would be compared to results obtained from generalized data and the numerical Pesticide Root Zone Model and the LEACH handbook. If the data determined onsite do not agree with the model and LEACH estimates, detailed site data would be used to calibrate the Pesticide Root Zone Model for each site. As necessary, the model would be modified to better represent conditions in Kansas. The model then would be used to define the contamination potential for given locations throughout the State.

\section{CONCLUSIONS}

An assessment of the hydrologic factors, agricultural factors, and chemical factors that may affect the leaching of agricultural chemicals to ground water was conducted to evaluate the extent and severity of agricultural chemical contamination of ground-water resources in Kansas. The climate of a particular area determines the length of the growing season and the availability of water, at the surface and in the ground, for the growth of plants. Climate, together with surficial geology, soil type, and principal aquifers, determines the types of crops to be planted, types of tillage, conservation and irrigation practices, and affects the quantity and method of application of agricultural chemicals.

In general, the greater the percentage of sand in the soil the more susceptible it will be to leaching and to contamination by agricultural chemicals. Soil in Kansas has been grouped into four classes of leachability--from class 1 , with the largest permeability, to class 4 , with the smallest.

Of the three major fertilizer compounds (nitrogen, phosphorus, and potassium), nitrogen is the most extensively used. As a result of years of nitrogen application to the soil, nitratenitrogen contamination has occurred in the ground water of each of 14 geohydrologic regions in the State. The $10-\mathrm{mg} / \mathrm{L}$ drinking-water standard for nitrate-nitrogen was exceeded occasionally in 13 of the 14 regions, based on water samples collected from $1976-81$ at 766 wells. Median nitrate-nitrogen concentrations exceeded $3 \mathrm{mg} / \mathrm{L}$ in seven of the regions; concentrations greater than $50 \mathrm{mg} / \mathrm{L}$ occurred in four of the regions. Phosphorus and potassium have very limited movement in the soil and virtually remain in the area of application.

Lime is used to treat soil that is acidic. Increased crop production on irrigated sandy soil in south-central and western Kansas frequently has resulted in soil $\mathrm{pH}$ values of less than 7. These small $\mathrm{pH}$ values may be the result of excessive nitrogen applications. One pound of ammonium nitrate may require as much as 6 pounds of lime to prevent an increase in acidity and to maintain optimum conditions for nitrification.

During 1978, about 23.8 million pounds of herbicides and 4.3 million pounds of insecticides were used in the State. Atrazine was the most extensively used herbicide, with 5.7 million pounds applied. However, in areal extent, 2,4-D was the most extensively used, being applied to more than 4 million acres. Atrazine was used extensively on corn and grain sorghum; 2,4-D, on pasture and rangeland. Use of each of seven herbicides exceeded 1 million pounds, but use of no single insecticide exceeded 1 million pounds. 
One or more pesticides were detected in about 20 percent (11) of the 56 wells from which samples were collected during 1985-86 in areas susceptible to agricultural chemical leaching. The most common group of pesticides detected was the triazine herbicides--atrazine, cyanazine, propazine, and simazine. Eleven samples of ground water from nine wells contained atrazine, with concentrations ranging from less than 0.1 to $46 \mu \mathrm{g} / \mathrm{L}$. Only two atrazine concentrations exceeded $2 \mu \mathrm{g} / \mathrm{L}$ ( 34 and $46 \mu \mathrm{g} / \mathrm{L})$. Four samples contained cyanazine in concentrations ranging from 0.7 to $3.7 \mu \mathrm{g} / \mathrm{L}$. Propazine $(0.2 \mu \mathrm{g} / \mathrm{L})$ and simazine $(0.1 \mu \mathrm{g} / \mathrm{L})$ were detected in only one sample (Sedgwick County, in south-central Kansas). Three other herbicides were also detected: alachlor (1.9 $\mu \mathrm{g} / \mathrm{L})$; metolachlor $(6.0 \mu \mathrm{g} / \mathrm{L}$ in water from one well, 43 and $55 \mu \mathrm{g} / \mathrm{L}$ in two water samples from another well); and metribuzin $(14 \mu \mathrm{g} / \mathrm{L})$ in one sample.

Because the largest concentrations of atrazine $(46 \mu \mathrm{g} / \mathrm{L})$, cyanazine $(3.7 \mu \mathrm{g} / \mathrm{L})$, metolachlor $(55$ $\mu \mathrm{g} / \mathrm{L})$, and the only detectable concentrations of metribuzin $(14 \mu \mathrm{g} / \mathrm{L})$ and alachlor $(1.9 \mu \mathrm{g} / \mathrm{L})$ were from water at only one site--the Hesston agronomy farm, approximately in the center of the State--it is uncertain how widespread the problem of large concentrations of these herbicides is throughout the State. It is noteworthy that the herbicides 2,4-D, 2,4,5-T, picloram, and alachlor and the insecticides chlordane and heptachlor epoxide have been detected by other researchers in ground water from domestic-supply wells in the State.

A plan of a proposed study of the leaching and fate of pesticides in the saturated and unsaturated zones in Kansas includes a comprehensive investigation of pesticides in soil and ground water, data collection, process interpretation, and numerical modeling.

\section{REFERENCES}

American Geological Institute, 1977, Bibliography and index of Kansas geology through 1974: Kansas Geological Survey Bulletin $213,183 \mathrm{p}$.

Barnes, P.L., Maddux, P.L., and Kissel, D.E., 1982, Management of nitrate leaching under irrigated agriculture: Dow Chemical Company, Research Report of Progress,
Manhattan, Kans., Kansas State University, 79

p.

1983, Management of nitrate leaching

under irrigated agriculture: Dow Chemical Company, Research Report of Progress, Manhattan, Kans., Kansas State University, $68 \mathrm{p}$.

Bayne, C.K., 1975, General availability of ground water and normal precipitation in Kansas: Kansas Geological Survey Map M$4 \mathrm{~A}$, scale $1: 500,000,1$ sheet.

Bevans, H.E., Spruill, T.B., and Kenny, J.F., 1985, Kansas ground-water resources, in National water summary 1984--Hydrologic events, selected water-quality trends and ground-water resources: U.S. Geological Survey Water-Supply Paper 2275, p. 217 222.

Burkhead, N., and Guth, J.A., 1976, Photodegradation of atrazine, atraton, and ametryne in aqueous solution with acetone as a photosensitizer: Pesticide Science, v. 7, no. 1, p. 65-71.

Carsel, R.F., Smith, C.N., Mulkey, L.A., Dean, J.D., and Jowise, Peter, 1984, Users manual for the pesticide root-zone model (PRZM): Athens, Georgia, U.S. Environmental Protection Agency, Environmental Research Laboratory, Release 1, EPA-600/3-84-109, $216 \mathrm{p}$.

Cohen, S.Z., Creeger, S.M., Carsel, R.F., and Enfield, C.G., 1984, Potential for pesticide contamination of ground water resulting from agricultural uses, preprint, treatment and disposal of pesticide wastes: American Chemical Society Symposium, $28 \mathrm{p}$.

Dean, J.D., Jowise, P.P., and Donigian, A.S., Jr., 1984, Leaching evaluation of agricultural chemicals (LEACH) handbook: Atlanta, Georgia, U.S. Environmental Protection Agency, Environmental Research Laboratory, EPA-600/3-84-068, 300 p.

Fenneman, N.M., 1946, Physical divisions of the United States: U.S. Geological Survey special map, scale 1: 7,000,000, 1 sheet.

Foth, H.D., 1978, Fundamentals of soil science, 6th ed.: New York, John Wiley \& Sons, 436 p.

Freeze, R.A., and Cherry, J.A., 1979, Groundwater: Englewood Cliffs, N.J., Prentice-Hall, Inc., $604 \mathrm{p}$.

Harris, C.I., 1967, Fate of 2 chloro-s-triazine herbicides in soil: Journal Agricultural Food Chemicals, v. 15, no. 1, p. 157-162. 
Helling, C.S., 1971, Pesticide mobility in soils-II. Applications of soil thin-layer chromotography: Soil Science Society American Proceedings, v. 35, p. 737-748.

Hurl, K., and Kibler, E., 1976, The effect of changing moisture conditions on the degradation of atrazine in soil: Proceedings of the British Crop Protection Conference-Weeds, v. 2, p. 627-633.

Kansas Department of Health and

Environment, 1986, Explanation of your drinking water analysis: Topeka, Kans., October 28, 1986, pamphlet.

Kansas State Board of Agriculture, 1980, 63rd annual report and farm facts: Topeka, Kans., 274 p.

1985,67 th annual report and farm facts:

Topeka, Kans., 265 p.

Kansas State University, 1982, Kansas irrigation survey, 1982: Manhattan, Cooperative Extension Service, 156 p.

Kissel, D.E., Bidwell, O.W., and Kientz, J.F., 1982, Leaching classes of Kansas soils: Manhattan, Kansas State University, Kansas Agricultural Experiment Station Bulletin 641, $10 \mathrm{p}$.

Kissel, D.E., and Virgil, Merle, 1985, Kansas fertilizer research: Manhattan, Kansas State University, Agricultural Experiment Station, $10 \mathrm{p}$.

Koelliker, J.K., Steiken, J.M., Yearout, R.D., Heiman, A.T., and Grosh, D.L., 1987, Indentification of factors affecting farmstead well water quality: Manhattan, Kans., Kansas Water Resources Research Institute, Report No. G1226-02, 50 p.

Lavy, T.L., 1974, Mobility and deactivation of herbicides in soil-water systems: National Technical Information Service, Springfield, Virginia: PB-238 632.

Love, J.R., 1979, General soil science workbook: Madison, Wis., University of Wisconsin at Madison, $196 \mathrm{p}$.

Maddux, L.D., Kissel, D.E., Ball, J.D., and Raney, R.J., 1985, Nitrification inhibition by nitrapyrin on irrigated corn: Journal of Fertilizer Issues, v. 2, no. 4, p. 124-129.

Maddux, L.D., Kissel, D.E., and Barnes, P.L., 1984, Effects of nitrogen source, placement, and application time on irrigated corn: Journal of Fertilizer Issues, v. 1, no. 3, p. 8690.
McCormick, L.L., and Hilbold, A.E., 1966, Miocrobiological decomposition of atrazine and diuron in soil: Weeds, v. 14, no. 1, p. 7782.

National Oceanic and Atmospheric Administration, 1983, Climatological data annual summary, Kansas: U.S. Department of Commerce, v. 97, no. 13, 34 p.

Nilson, E.B., and Johnson, M.E., 1980, Kansas 1978 pesticide usage: Manhattan, Kansas State Board of Agriculture, Cooperative Extension Service, Kansas State University, Manhattan, $8 \mathrm{p}$.

Nilson, E.B., Russ, O.G., Brotemarkle, J.K., Fick, W.H., Marishita, D.W., Stahlman, P.W., Kuhlman, D.K., and Ohlenbusch, P.D., 1987, Chemical weed control for field crops, pastures, rangeland, and noncropland, 1987: Manhattan, Agricultural Experiment Station, Kansas State University, 48 p.

Sine, Charlotte, 1988, Farm chemicals handbook 88: Willoughby, Ohio, Meister Publishing Company, $523 \mathrm{p}$.

Spruill, T.B., 1983, Statistical summaries of selected chemical constituents in Kansas ground-water supplies, 1976-81: U.S. Geological Survey Open-File Report 83-263, $29 \mathrm{p}$.

Steichen, James, Roelliker, James, and Grosh, Doris, 1986, Kansas farmstead well survey for contamination by pesticides and volatile organics: National Water Well Association, Proceedings of the Agricultural Impacts on Ground Water, August 11-13, 1986, p. 530541.

Thomas, J.G., 1982, Kansas irrigation survey: Manhattan, Kansas State University, Cooperative Extension Service, $5 \mathrm{p}$.

U.S. Department of Agriculture Soil Survey Staff, 1951, Soil survey manual: U.S. Department of Agriculture Handbook 18, U.S. Government Printing Office, Washington, D.C.

U.S. Environmental Protection Agency, 1986a, Maximum contaminant levels (subpart B of part 141, National interim primary drinking-water regulations): U.S. Code of Federal Regulations, Title 40, Parts 100 to 149 , revised as of July 1, 1986, p. 524-528. 
1986b, Secondary maximum contaminant levels (section 143.3 of part 143, national secondary drinking-water regulations): U.S. Code of Federal Regulations, Title 40, Parts 100 to 149 , revised as of July 1,1986 , p. 587590.

Weidner, C.W., 1974, Degradation in groundwater and mobility of herbicides: Springfield, Va., National Technical Information Service, PB-239 242, 69 p.

Whitney, D.A., 1976, Soil test interpretations and fertilizer recommendations: Manhattan, Kansas State University, Cooperative Extension Service, Report No. C-509, 11 p.

Windholz, Martha, 1983, The Merck Index, 10th ed.: New Jersey, Merck and Company, Inc., $1463 \mathrm{p}$. 
SUPPLEMENTAL INFORMATION 
Table 18. Major herbicide usage during 1978, by reporting district [Data from Nilson and Johnson, 1980]

\begin{tabular}{|c|c|c|c|c|c|}
\hline Common & Trade & Crop & Area $1 /$ & Percentage & Total2/ \\
\hline \multirow[t]{2}{*}{ name } & name & & applied & of crop & applied \\
\hline & & & (acre) & acreage & (pounds) \\
\hline
\end{tabular}

\section{Northwest Kansas}

\begin{tabular}{|c|c|c|c|c|c|}
\hline Atrazine & AAtrex & $\begin{array}{l}\text { Corn } \\
\text { Sorghum } \\
\text { Al1 }\end{array}$ & $\begin{array}{r}216,300 \\
65,500 \\
281,800\end{array}$ & $\begin{array}{l}89 \\
34\end{array}$ & $\begin{array}{l}352,600 \\
108,700 \\
461,300\end{array}$ \\
\hline EPTC & Eradicane & Corn & 78,000 & 32 & 330,700 \\
\hline Alach1or & Lasso & Corn & 61,500 & 25 & 124,200 \\
\hline $2,4-D$ & -- & $\begin{array}{l}\text { Corn } \\
\text { Sorghum } \\
\text { Wheat } \\
\text { Pasture } \\
\text { Al1 }\end{array}$ & $\begin{array}{r}9,600 \\
11,000 \\
113,600 \\
9,800 \\
144,000\end{array}$ & $\begin{array}{l}4 \\
6 \\
9 \\
1\end{array}$ & $\begin{array}{r}4,300 \\
4,800 \\
71,600 \\
16,600 \\
97,300\end{array}$ \\
\hline Propachlor & Ramrod & $\begin{array}{l}\text { Corn } \\
\text { Sorghum } \\
\text { Al1 }\end{array}$ & $\begin{array}{r}4,500 \\
15,300 \\
19,800\end{array}$ & $\begin{array}{l}2 \\
8\end{array}$ & $\begin{array}{l}16,000 \\
51,400 \\
67,400\end{array}$ \\
\hline Cyanazine & Bladex & $\begin{array}{l}\text { Corn } \\
\text { Sorghum } \\
\text { A11 }\end{array}$ & $\begin{array}{l}23,900 \\
11,200 \\
35,100\end{array}$ & $\begin{array}{r}10 \\
6\end{array}$ & $\begin{array}{l}45,600 \\
13,900 \\
59,500\end{array}$ \\
\hline Propazine & Milogard & Sorghum & 40,300 & 21 & 53,200 \\
\hline Terbutryn & Igran & Sorghum & 18,200 & 10 & 31,900 \\
\hline Dicamba & Benvel & $\begin{array}{l}\text { Corn } \\
\text { Sorghum } \\
\text { A11 }\end{array}$ & $\begin{array}{r}23,500 \\
6,200 \\
29,800\end{array}$ & $\begin{array}{r}10 \\
3 \\
3\end{array}$ & $\begin{array}{l}8,000 \\
1,600 \\
9,600\end{array}$ \\
\hline
\end{tabular}


Table 18. Major herbicide usage during 1978 , by reporting district

[Data from Nilson and Johnson, 1980]--Continued

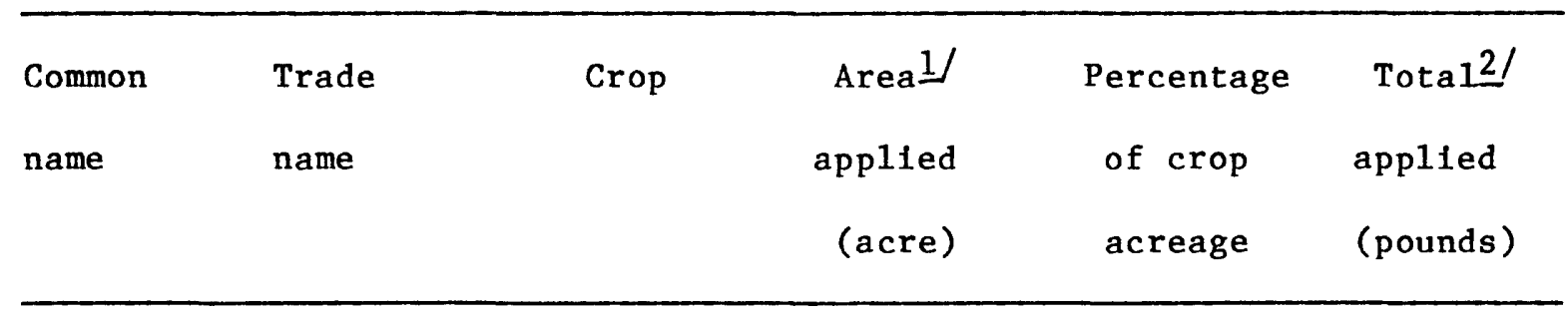

North-Centra1 Kansas

\begin{tabular}{|c|c|c|c|c|c|}
\hline $2,4-D$ & -- & $\begin{array}{l}\text { Corn } \\
\text { Sorghum } \\
\text { Wheat } \\
\text { Pasture } \\
\text { A11 }\end{array}$ & $\begin{array}{r}4,000 \\
104,200 \\
201,600 \\
452,500 \\
762,400\end{array}$ & $\begin{array}{r}4 \\
15 \\
15 \\
19\end{array}$ & $\begin{array}{r}1,800 \\
45,800 \\
127,000 \\
764,700 \\
939,300\end{array}$ \\
\hline Propach1or & Ramrod & $\begin{array}{l}\text { Corn } \\
\text { Sorghum } \\
\text { A11 }\end{array}$ & $\begin{array}{r}9,400 \\
225,200 \\
234,600\end{array}$ & $\begin{array}{r}9 \\
33\end{array}$ & $\begin{array}{r}33,400 \\
756,700 \\
790,100\end{array}$ \\
\hline Atrazine & AAtrex & $\begin{array}{l}\text { Corn } \\
\text { Sorghum } \\
\text { A11 }\end{array}$ & $\begin{array}{r}73,300 \\
367,200 \\
440,500\end{array}$ & $\begin{array}{l}67 \\
54\end{array}$ & $\begin{array}{l}119,500 \\
609,500 \\
729,000\end{array}$ \\
\hline EPTC & Eradicane & Corn & 30,000 & 27 & 127,500 \\
\hline Propazine & Milogard & Sorghum & 78,400 & 12 & 103,500 \\
\hline Cyanazine & Bladex & $\begin{array}{l}\text { Corn } \\
\text { Sorghum } \\
\text { A11 }\end{array}$ & $\begin{array}{r}13,800 \\
9,900 \\
23,700\end{array}$ & $\begin{array}{r}13 \\
1\end{array}$ & $\begin{array}{l}26,400 \\
12,300 \\
38,700\end{array}$ \\
\hline Alachlor & Lasso & $\begin{array}{l}\text { Corn } \\
\text { Soybeans } \\
\text { A11 }\end{array}$ & $\begin{array}{r}5,300 \\
12,200 \\
17,500\end{array}$ & $\begin{array}{l}5 \\
2\end{array}$ & $\begin{array}{l}10,700 \\
27,900 \\
38,600\end{array}$ \\
\hline Terbutryn & Igran & Sorghum & 21,500 & 3 & 37,600 \\
\hline Dicamba & Banvel & $\begin{array}{l}\text { Sorghum } \\
\text { Wheat } \\
\text { A11 }\end{array}$ & $\begin{array}{r}6,600 \\
22,400 \\
29,000\end{array}$ & $\begin{array}{l}1 \\
2\end{array}$ & $\begin{array}{l}1,700 \\
2,900 \\
4,600\end{array}$ \\
\hline
\end{tabular}


Table 18. Major herbicide usage during 1978 , by reporting district

[Data from Nilson and Johnson, 1980]--Continued

\begin{tabular}{|c|c|c|c|c|c|}
\hline $\begin{array}{l}\text { Common } \\
\text { name }\end{array}$ & $\begin{array}{l}\text { Trade } \\
\text { name }\end{array}$ & Crop & $\begin{array}{l}\text { Area } 1 / \\
\text { applied } \\
\text { (acre) }\end{array}$ & $\begin{array}{l}\text { Percentage } \\
\text { of crop } \\
\text { acreage }\end{array}$ & $\begin{array}{l}\text { Tota12/ } \\
\text { applied } \\
\text { (pounds) }\end{array}$ \\
\hline \multicolumn{6}{|c|}{ Northeast Kansas } \\
\hline $2,4-D$ & -- & $\begin{array}{l}\text { Corn } \\
\text { Sorghum } \\
\text { Wheat } \\
\text { Pasture } \\
\text { Al1 }\end{array}$ & $\begin{array}{r}17,500 \\
65,600 \\
12,900 \\
630,400 \\
726,400\end{array}$ & $\begin{array}{r}7 \\
11 \\
5 \\
37\end{array}$ & $\begin{array}{r}7,900 \\
28,900 \\
8,100 \\
1,065,400 \\
1,110,300\end{array}$ \\
\hline Atrazine & AAtrex & $\begin{array}{l}\text { Corn } \\
\text { Sorghum } \\
\text { A1I }\end{array}$ & $\begin{array}{l}202,000 \\
450,300 \\
652,200\end{array}$ & $\begin{array}{l}77 \\
77\end{array}$ & $\begin{array}{r}329,300 \\
747,500 \\
1,076,800\end{array}$ \\
\hline Propachlor & Ramrod & $\begin{array}{l}\text { Corn } \\
\text { Sorghum } \\
\text { A11 }\end{array}$ & $\begin{array}{r}12,200 \\
295,200 \\
307,400\end{array}$ & $\begin{array}{r}5 \\
50\end{array}$ & $\begin{array}{r}43,300 \\
991,900 \\
1,035,200\end{array}$ \\
\hline Alachlor & Lasso & $\begin{array}{l}\text { Corn } \\
\text { Soybeans } \\
\text { A11 }\end{array}$ & $\begin{array}{r}75,600 \\
105,400 \\
181,000\end{array}$ & $\begin{array}{l}29 \\
38\end{array}$ & $\begin{array}{l}152,700 \\
241,400 \\
394,100\end{array}$ \\
\hline Butylate & Sutant & Corn & 52,900 & 20 & 238,100 \\
\hline EPTC & Eradicane & Corn & 46,500 & 18 & 197,600 \\
\hline Trifluralin & Treflan & Soybeans & 109,300 & 40 & 136,600 \\
\hline Metribuzin & Sencor & Soybeans & 150,200 & 54 & 64,600 \\
\hline Cyanazine & Bladex & $\begin{array}{l}\text { Corn } \\
\text { Sorghum } \\
\text { A11 }\end{array}$ & $\begin{array}{r}23,700 \\
5,600 \\
29,300\end{array}$ & $\begin{array}{l}9 \\
1\end{array}$ & $\begin{array}{r}45,300 \\
6,900 \\
52,200\end{array}$ \\
\hline Chloramben & Amiben & Soybeans & 21,900 & 8 & 43,800 \\
\hline
\end{tabular}


Table 18. Major herbicide usage during 1978, by reporting district

[Data from Nilson and Johnson, 1980]-Continued

\begin{tabular}{|c|c|c|c|c|c|}
\hline $\begin{array}{l}\text { Common } \\
\text { name }\end{array}$ & $\begin{array}{l}\text { Trade } \\
\text { name }\end{array}$ & Crop & $\begin{array}{l}\text { Areal } \\
\text { applied } \\
\text { (acre) }\end{array}$ & $\begin{array}{l}\text { Percentage } \\
\text { of crop } \\
\text { acreage }\end{array}$ & $\begin{array}{l}\text { Total2/ } \\
\text { applied } \\
\text { (pounds) }\end{array}$ \\
\hline \multicolumn{6}{|c|}{ West-Central Kansas } \\
\hline Atrazine & AAtrex & $\begin{array}{l}\text { Corn } \\
\text { Sorghum } \\
\text { A11 }\end{array}$ & $\begin{array}{r}154,500 \\
56,400 \\
210,900\end{array}$ & $\begin{array}{l}79 \\
27\end{array}$ & $\begin{array}{r}251,800 \\
93,600 \\
345,400\end{array}$ \\
\hline EPTC & Eradicane & Corn & 67,000 & 34 & 284,800 \\
\hline $2,4-D$ & -- & $\begin{array}{l}\text { Corn } \\
\text { Sorghum } \\
\text { Wheat } \\
\text { Pasture } \\
\text { A11 }\end{array}$ & $\begin{array}{r}2,400 \\
14,100 \\
158,600 \\
15,400 \\
190,500\end{array}$ & $\begin{array}{r}1 \\
7 \\
12 \\
1\end{array}$ & $\begin{array}{r}1,100 \\
6,200 \\
99,900 \\
26,000 \\
133,200\end{array}$ \\
\hline Propazine & Milogard & Sorghum & 66,000 & 31 & 87,100 \\
\hline Terbutryn & Igran & Sorghum & 45,400 & 22 & 79,500 \\
\hline Cyanazine & Bladex & $\begin{array}{l}\text { Corn } \\
\text { Sorghum } \\
\text { A11 }\end{array}$ & $\begin{array}{l}17,700 \\
26,600 \\
44,300\end{array}$ & $\begin{array}{r}9 \\
13\end{array}$ & $\begin{array}{l}33,800 \\
33,000 \\
66,800\end{array}$ \\
\hline Butylate & Sutant & Corn & 9,000 & 5 & 40,500 \\
\hline Propachlor & Ramrod & $\begin{array}{l}\text { Corn } \\
\text { Sorghum } \\
\text { A11 }\end{array}$ & $\begin{array}{r}600 \\
6,100 \\
6,700\end{array}$ & $\begin{array}{r}<1 \\
3\end{array}$ & $\begin{array}{r}2,100 \\
20,500 \\
22,600\end{array}$ \\
\hline
\end{tabular}


Table 18. Major herbicide usage during 1978, by reporting district

[Data from Nilson and Johnson, 1980]--Continued

\begin{tabular}{|c|c|c|c|c|c|}
\hline $\begin{array}{l}\text { Common } \\
\text { name }\end{array}$ & $\begin{array}{l}\text { Trade } \\
\text { name }\end{array}$ & Crop & $\begin{array}{l}\text { Area } 1 / \\
\text { applied } \\
\text { (acre) }\end{array}$ & $\begin{array}{l}\text { Percentage } \\
\text { of crop } \\
\text { acreage }\end{array}$ & $\begin{array}{l}\text { Tota12/ } \\
\text { applied } \\
\text { (pounds) }\end{array}$ \\
\hline \multicolumn{6}{|c|}{ Central Kansas } \\
\hline $2,4-D$ & -- & $\begin{array}{l}\text { Corn } \\
\text { Sorghum } \\
\text { Wheat } \\
\text { Pasture } \\
\text { A11 }\end{array}$ & $\begin{array}{r}5,700 \\
114,100 \\
207,000 \\
192,700 \\
519,500\end{array}$ & $\begin{array}{r}9 \\
18 \\
12 \\
9 \\
9\end{array}$ & $\begin{array}{r}2,600 \\
50,200 \\
130,400 \\
325,700 \\
508,900\end{array}$ \\
\hline Atrazine & AAtrex & $\begin{array}{l}\text { Corn } \\
\text { Sorghum } \\
\text { A11 }\end{array}$ & $\begin{array}{r}24,100 \\
204,800 \\
228,900\end{array}$ & $\begin{array}{l}39 \\
32\end{array}$ & $\begin{array}{r}39,300 \\
340,000 \\
379,300\end{array}$ \\
\hline Propachlor & Ramrod & $\begin{array}{l}\text { Corn } \\
\text { Sorghum, } \\
\text { All }\end{array}$ & $\begin{array}{r}1,500 \\
56,000 \\
57,500\end{array}$ & $\begin{array}{l}2 \\
9\end{array}$ & $\begin{array}{r}5,300 \\
188,200 \\
193,500\end{array}$ \\
\hline Propazine & Milogard & Sorghum & 138,300 & 21 & 182,500 \\
\hline Terbutryn & Igran & Sorghum & 63,000 & 10 & 110,300 \\
\hline Alachlor & Lasso & $\begin{array}{l}\text { Corn } \\
\text { Soybeans } \\
\text { A11 }\end{array}$ & $\begin{array}{r}15,800 \\
8,400 \\
24,200\end{array}$ & $\begin{array}{l}26 \\
29\end{array}$ & $\begin{array}{l}31,900 \\
19,200 \\
51,200\end{array}$ \\
\hline Cyanazine & Bladex & $\begin{array}{l}\text { Corn } \\
\text { Sorghum } \\
\text { A11 }\end{array}$ & $\begin{array}{l}13,000 \\
10,200 \\
23,200\end{array}$ & $\begin{array}{r}21 \\
2\end{array}$ & $\begin{array}{l}24,800 \\
12,600 \\
37,400\end{array}$ \\
\hline Butylate & Sutant & Corn & 7,200 & 12 & 32,400 \\
\hline
\end{tabular}


Table 18. Major herbicide usage during 1978 , by reporting district

[Data from Nilson and Johnson, 1980]--Continued

\begin{tabular}{|c|c|c|c|c|c|}
\hline Common & Trade & Crop & Area 1$]$ & Percentage & Tota12/ \\
\hline name & name & & $\begin{array}{l}\text { applied } \\
\text { (acre) }\end{array}$ & $\begin{array}{l}\text { of crop } \\
\text { acreage }\end{array}$ & $\begin{array}{l}\text { applied } \\
\text { (pounds) }\end{array}$ \\
\hline
\end{tabular}

East-Centra1 Kansas

\begin{tabular}{|c|c|c|c|c|c|}
\hline Atrazine & AAtrex & $\begin{array}{l}\text { Corn } \\
\text { Sorghum } \\
\text { A11 }\end{array}$ & $\begin{array}{l}122,700 \\
357,300 \\
480,000\end{array}$ & $\begin{array}{l}71 \\
75\end{array}$ & $\begin{array}{l}200,000 \\
593,100 \\
793,100\end{array}$ \\
\hline $2,4-D$ & - & $\begin{array}{l}\text { Corn } \\
\text { Sorghum } \\
\text { Wheat } \\
\text { Pasture } \\
\text { A11 }\end{array}$ & $\begin{array}{r}15,400 \\
71,000 \\
22,500 \\
383,100 \\
492,000\end{array}$ & $\begin{array}{r}9 \\
15 \\
10 \\
14\end{array}$ & $\begin{array}{r}6,900 \\
31,200 \\
14,200 \\
647,400 \\
699,800\end{array}$ \\
\hline Propaclor & Ramrod & $\begin{array}{l}\text { Corn } \\
\text { Sorghum } \\
\text { All }\end{array}$ & $\begin{array}{r}5,900 \\
190,400 \\
196,300\end{array}$ & $\begin{array}{r}3 \\
40\end{array}$ & $\begin{array}{r}20,900 \\
639,700 \\
660,600\end{array}$ \\
\hline Alachlor & Lasso & $\begin{array}{l}\text { Corn } \\
\text { Soybeans } \\
\text { A11 }\end{array}$ & $\begin{array}{r}38,400 \\
130,900 \\
169,300\end{array}$ & $\begin{array}{l}22 \\
29\end{array}$ & $\begin{array}{r}77,600 \\
299,800 \\
377,400\end{array}$ \\
\hline Trifluralin & Treflan & Soybeans & 166,900 & 37 & 208,600 \\
\hline Butylate & Sutant & Corn & 41,100 & 24 & 185,000 \\
\hline EPTC & Eradicane & Corn & 16,600 & 10 & 70,300 \\
\hline Metribuzin & Sencor & Soybeans & 136,300 & 30 & 58,600 \\
\hline Cyanazine & B1adex & $\begin{array}{l}\text { Corn } \\
\text { Sorghum } \\
\text { Al1 }\end{array}$ & $\begin{array}{r}20,100 \\
9,400 \\
29,500\end{array}$ & $\begin{array}{r}12 \\
2\end{array}$ & $\begin{array}{l}38,400 \\
11,700 \\
50,100\end{array}$ \\
\hline Linuron & Lorox & Soybeans & 31,300 & 7 & 31,300 \\
\hline
\end{tabular}


Table 18. Major herbicide usage during 1978 , by reporting district

[Data from Nilson and Johnson, 1980]--Continued

\begin{tabular}{|c|c|c|c|c|c|}
\hline $\begin{array}{l}\text { Common } \\
\text { name }\end{array}$ & $\begin{array}{l}\text { Trade } \\
\text { name }\end{array}$ & Crop & $\begin{array}{c}\text { Area } 1 / \\
\text { applied } \\
\text { (acre) }\end{array}$ & $\begin{array}{l}\text { Percentage } \\
\text { of crop } \\
\text { acreage }\end{array}$ & $\begin{array}{l}\text { Total2/ } \\
\text { applied } \\
\text { (pounds) }\end{array}$ \\
\hline \multicolumn{6}{|c|}{ Southwest Kansas } \\
\hline Atrazine & AAtrex & $\begin{array}{l}\text { Corn } \\
\text { Sorghum } \\
\text { A11 }\end{array}$ & $\begin{array}{l}437,100 \\
105,400 \\
542,500\end{array}$ & $\begin{array}{l}78 \\
14\end{array}$ & $\begin{array}{l}712,500 \\
175,000 \\
887,500\end{array}$ \\
\hline Butylate & Sutant & Corn & 134,900 & 24 & 607,100 \\
\hline EPTC & Eradicane & Corn & 98,900 & 18 & 420,300 \\
\hline $2,4-D$ & -- & $\begin{array}{l}\text { Corn } \\
\text { Sorghum } \\
\text { Wheat } \\
\text { Pasture } \\
\text { AlI }\end{array}$ & $\begin{array}{r}8,800 \\
74,100 \\
39,500 \\
93,500 \\
215,900\end{array}$ & $\begin{array}{r}2 \\
10 \\
2 \\
4\end{array}$ & $\begin{array}{r}4,000 \\
32,600 \\
24,900 \\
158,000 \\
219,500\end{array}$ \\
\hline Propazine & Milogard & Sorghum & 157,900 & 21 & 208,400 \\
\hline Terbutryn & Igran & Sorghum & 113,000 & 15 & 197,800 \\
\hline Propachlor & Ramrod & $\begin{array}{l}\text { Corn } \\
\text { Sorghum } \\
\text { A11 }\end{array}$ & $\begin{array}{r}6,700 \\
26,300 \\
33,000\end{array}$ & $\begin{array}{l}1 \\
3 \\
3\end{array}$ & $\begin{array}{r}23,800 \\
88,400 \\
112,200\end{array}$ \\
\hline Cyanazine & Bladex & $\begin{array}{l}\text { Corn } \\
\text { Sorghum } \\
\text { A11 }\end{array}$ & $\begin{array}{r}25,000 \\
7,600 \\
32,600\end{array}$ & $\begin{array}{l}4 \\
1\end{array}$ & $\begin{array}{r}47,800 \\
9,400 \\
57,200\end{array}$ \\
\hline Alachlor & Lasso & Corn & 18,500 & 3 & 37,400 \\
\hline
\end{tabular}


Table 18. Major herbicide usage during 1978, by reporting district

[Data from Nilson and Johnson, 1980]--Continued

\begin{tabular}{|c|c|c|c|c|c|}
\hline $\begin{array}{l}\text { Common } \\
\text { name }\end{array}$ & $\begin{array}{l}\text { Trade } \\
\text { name }\end{array}$ & Crop & $\begin{array}{l}\text { Area } 1 / \\
\text { applied } \\
\text { (acre) }\end{array}$ & $\begin{array}{l}\text { Percentage } \\
\text { of crop } \\
\text { acreage }\end{array}$ & $\begin{array}{l}\text { Total2/ } \\
\text { applied } \\
\text { (pounds) }\end{array}$ \\
\hline \multicolumn{6}{|c|}{ South-Central Kansas } \\
\hline $2,4-D$ & -- & $\begin{array}{l}\text { Corn } \\
\text { Sorghum } \\
\text { Wheat } \\
\text { Pasture } \\
\text { A11 }\end{array}$ & $\begin{array}{r}900 \\
83,300 \\
192,200 \\
146,500 \\
422,900\end{array}$ & $\begin{array}{r}<1 \\
13 \\
7 \\
6\end{array}$ & $\begin{array}{r}400 \\
36,700 \\
121,100 \\
247,600 \\
405,800\end{array}$ \\
\hline Atrazine & AAtrex & $\begin{array}{l}\text { Corn } \\
\text { Sorghum } \\
\text { A11 }\end{array}$ & $\begin{array}{r}97,100 \\
128,900 \\
226,000\end{array}$ & $\begin{array}{l}75 \\
20\end{array}$ & $\begin{array}{l}158,300 \\
214,000 \\
372,300\end{array}$ \\
\hline Propachlor & Ramrod & $\begin{array}{l}\text { Corn } \\
\text { Sorghum } \\
\text { A11 }\end{array}$ & $\begin{array}{r}4,000 \\
99,500 \\
103,500\end{array}$ & $\begin{array}{r}3 \\
16\end{array}$ & $\begin{array}{r}14,200 \\
334,300 \\
348,500\end{array}$ \\
\hline Propazine & Milogard & Sorghum & 133,500 & 21 & 176,200 \\
\hline Alachlor & Lasso & $\begin{array}{l}\text { Corn } \\
\text { Soybeans } \\
\text { Al1 }\end{array}$ & $\begin{array}{l}64,500 \\
11,600 \\
76,100\end{array}$ & $\begin{array}{l}50 \\
14\end{array}$ & $\begin{array}{r}130,300 \\
26,600 \\
156,900\end{array}$ \\
\hline Terbutryn & Igran & Sorghum & 70,700 & 11 & 123,700 \\
\hline Butylate & Sutant & Corn & 16,100 & 12 & 72,500 \\
\hline Trifluralin & Treflan & Soybeans & 43,800 & 53 & 54,800 \\
\hline Dicamba & Banvel & $\begin{array}{l}\text { Corn } \\
\text { Sorghum } \\
\text { Wheat } \\
\text { A11 }\end{array}$ & $\begin{array}{r}200 \\
6,000 \\
50,900 \\
57,100\end{array}$ & $\begin{array}{r}<1 \\
1 \\
2\end{array}$ & $\begin{array}{r}70 \\
1,500 \\
6,600 \\
8,170\end{array}$ \\
\hline
\end{tabular}


Table 18. Major herbicide usage during 1978 , by reporting district

[Data from Nilson and Johnson, 1980]--Continued

\begin{tabular}{|c|c|c|c|c|c|}
\hline $\begin{array}{l}\text { Common } \\
\text { name }\end{array}$ & $\begin{array}{l}\text { Trade } \\
\text { name }\end{array}$ & Crop & $\begin{array}{l}\text { Area } 1 / \\
\text { applied } \\
\text { (acre) }\end{array}$ & $\begin{array}{l}\text { Percentage } \\
\text { of crop } \\
\text { acreage }\end{array}$ & $\begin{array}{l}\text { Tota1 } 2 / \\
\text { applied } \\
\text { (pounds) }\end{array}$ \\
\hline \multicolumn{6}{|c|}{ Southeast Kansas } \\
\hline $2,4-D$ & -- & $\begin{array}{l}\text { Corn } \\
\text { Sorghum } \\
\text { Wheat } \\
\text { Pasture } \\
\text { A11 }\end{array}$ & $\begin{array}{r}4,900 \\
73,700 \\
76,200 \\
374,100 \\
528,900\end{array}$ & $\begin{array}{r}6 \\
14 \\
16 \\
10\end{array}$ & $\begin{array}{r}2,200 \\
32,400 \\
48,000 \\
632,200 \\
714,800\end{array}$ \\
\hline Atrazine & AAtrex & $\begin{array}{l}\text { Corn } \\
\text { Sorghum } \\
\text { A11 }\end{array}$ & $\begin{array}{r}65,500 \\
343,800 \\
409,300\end{array}$ & $\begin{array}{l}80 \\
67\end{array}$ & $\begin{array}{l}106,800 \\
570,700 \\
677,500\end{array}$ \\
\hline Propachlor & Ramrod & $\begin{array}{l}\text { Corn } \\
\text { Sorghum } \\
\text { A11 }\end{array}$ & $\begin{array}{r}3,800 \\
160,000 \\
163,800\end{array}$ & $\begin{array}{r}5 \\
31\end{array}$ & $\begin{array}{r}13,500 \\
537,600 \\
551,100\end{array}$ \\
\hline Alaclor & Lasso & $\begin{array}{l}\text { Corn } \\
\text { Soybeans } \\
\text { A11 }\end{array}$ & $\begin{array}{r}21,200 \\
136,600 \\
157,800\end{array}$ & $\begin{array}{l}26 \\
27\end{array}$ & $\begin{array}{r}42,800 \\
312,800 \\
355,600\end{array}$ \\
\hline Trefluralin & Treflan & Soybeans & 199,700 & 34 & 249,600 \\
\hline Butylate & Sutant & Corn & 13,300 & 16 & 59,900 \\
\hline Metribuzin & Sencor & Soybeans & 135,900 & 23 & 58,400 \\
\hline Linuron & Lorox & Soybeans & 31,800 & 5 & 31,800 \\
\hline Bentazon & Basagran & Soybeans & 28,400 & 5 & 28,400 \\
\hline
\end{tabular}

1 The "area applied" includes acres where a pesticide is used alone or in combination; a given area may recelve multiple pesticides.

2 The "total applied" was derived by multiplying the "area applied" by the the statewide average application rate for each herbicide on each crop. 